\author{
JURACY MACHADO PACÍFICO \\ RENATA APARECIDA CARBONE MIZUSAKI \\ SIRLEY LEITE FREITAS \\ JOSÉLIA GOMES NEVES \\ (Organizadoras)
}

\title{
Experiências na educação infantil: narrar e refletir é preciso
}

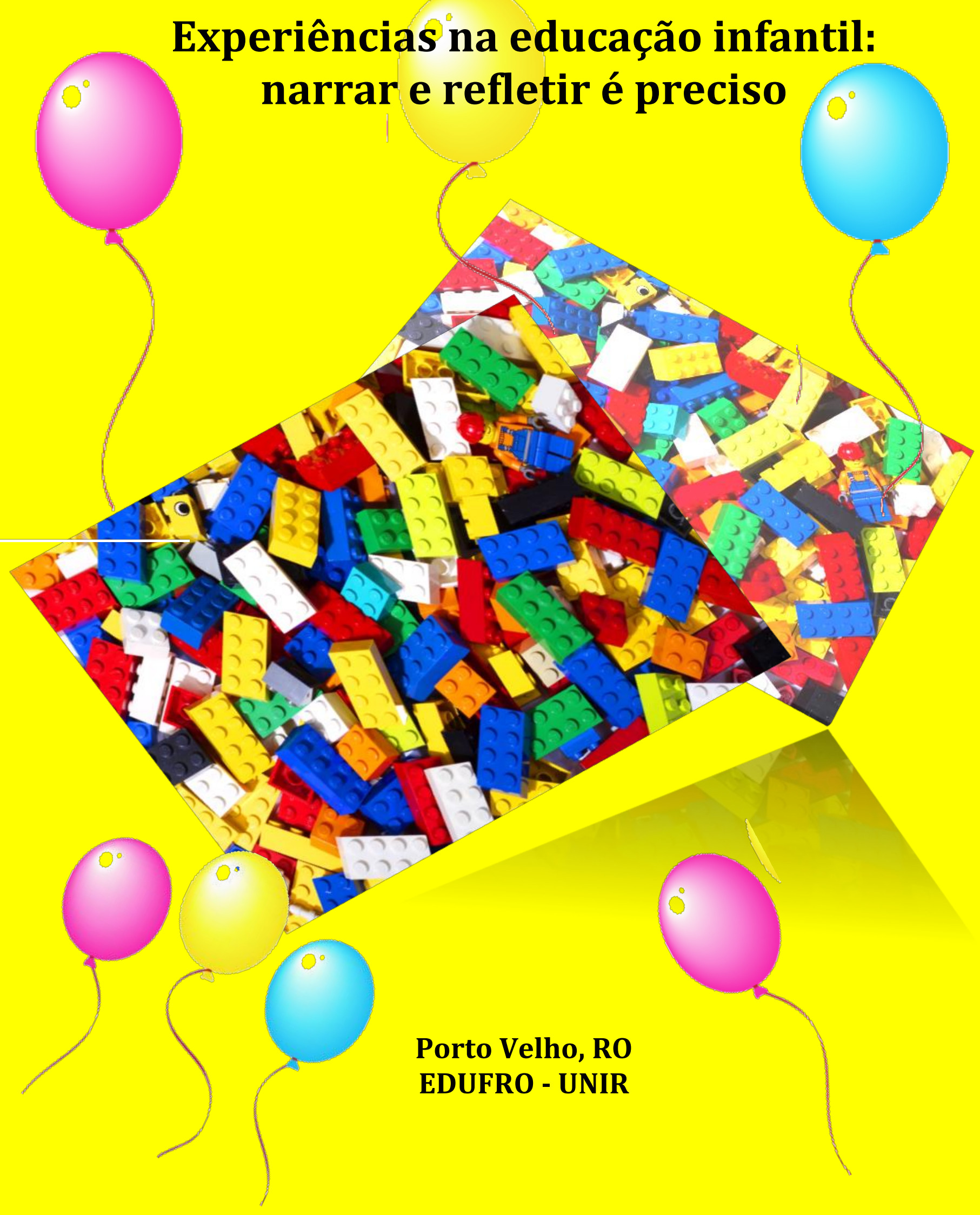





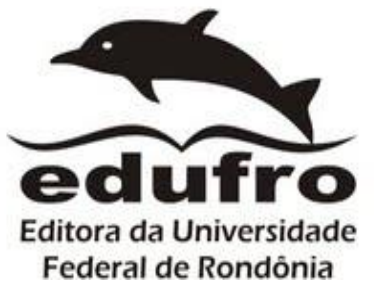

Federal de Rondônia

\author{
Av. Presidente Dutra, 2965 - Centro \\ Porto Velho - RO - CEP: 76801-974 \\ Fone: (69) 2182-2000 \\ www.edufro.unir.br \\ edufro@unir.br
}




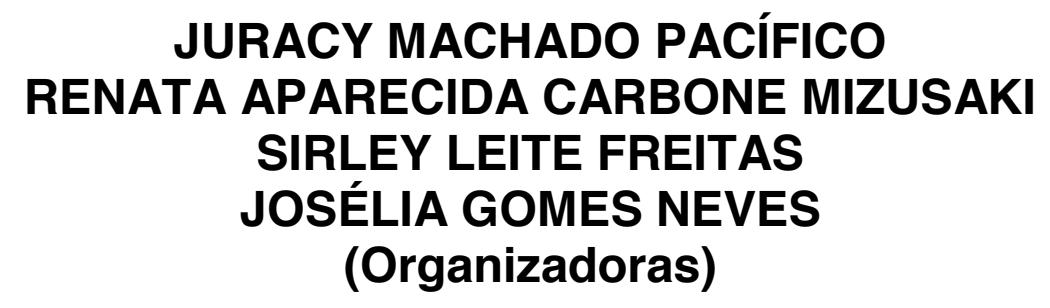

\section{Experiências na educação infantil: narrar e refletir é preciso}


E695

Experiências na educaçăo infantil: narrar e refletir é preciso / Organizadoras Juracy Machado Pacifico, Renata Aparecida Carbone Mizusaki, Sirley Leite Freitas, Josélia Gomes Neves. Edufro, Porto Velho, Rondônia, 2017.

$118 \mathrm{p}$.

ISBN: 978-85-7764-089-8

1. Educação infantil 2. Práticas pedagógicas 3. Formação docente I. Pacífico, Juracy Machado II. Misuzaki, Renata Aparecida Carbone III. Freitas, Sirley Leite IV. Neves, Josélia Gomes V.Título.

CDU: $37-053.2$

Bibliotecária Responsável: Ozelina Saldanha CRB11/486

Preparo de originais: Autores

Revisão Gramatical: Autores

Revisão de Normas Técnicas: Autores
Capa: Juracy Machado Pacífico Composição: EDUFRO

Editor: Jairo André Schlindwein

Fundação Universidade Federal de Rondônia

\author{
Ari Miguel Teixeira Ott \\ Reitor \\ Marcelo Vergotti \\ Vice-Reitor \\ Adilson Siqueira de Andrade \\ Chefe de Gabinete \\ Charles Dam Souza Silva \\ Pró-Reitor de Administração
}

Otacílio Moreira de Carvalho Costa Pró-Reitor de Planejamento

Jorge Luiz Coimbra de Oliveira Pró-Reitora de Graduação

Valdir Aparecido de Souza Pró-Reitora de Pós-Graduação e Pesquisa

Rubens Vaz Cavalcante

Pró-Reitor de Cultura, Extensão e Assuntos

Estudantis

\section{Conselho Editorial da EDUFRO}

Jairo André Schlindwein (Prof. UNIR), José Lucas Pedreira Bueno (Prof. UNIR), Emanuel Fernando Maia de Souza (Prof. UNIR), Rubiani de Cássia Pagotto (Profa. UNIR), Osmar Siena (Prof. UNIR), Júlio César Barreto Rocha (Prof. UNIR), Marli Lucia Tonatto Zibetti (Profa. UNIR), Sirlaine Galhardo Gomes Costa (Bibliotecária UNIR), Cléberson de Freitas Fernandes (EMBRAPA), Dante Ribeiro da Fonseca (ACLER)

Depósito legal na Biblioteca Nacional conforme Lei no 10.994, 14 de dezembro de 2004.

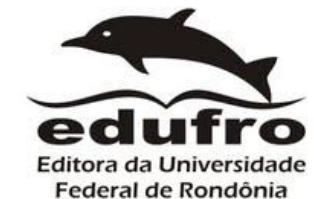

Av. Presidente Dutra, 2965 - Centro

Porto Velho - RO - CEP: 76801-974

Fone: (69) 2182-2000

www.edufro.unir.br

edufro@unir.br 


\section{SUMÁRIO}

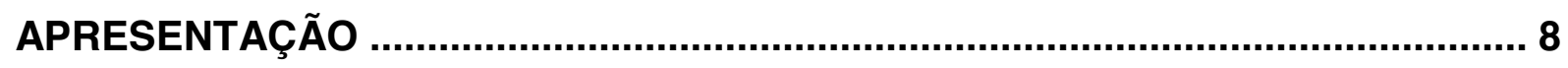

PARTE I Contribuições aos estudos sobre as crianças e as infâncias:

reflexões teóricas

Acenos para uma sociologia da infância no Brasil.

João Clemente de Souza Neto

Sobre as infâncias e o modo de ser das crianças.

Rozane Alonso Alves

Corpos que brincam: ciranda do consumo e culturas infantis

Renata Aparecida Carbone Mizusaki

Cleomar Ferreira Gomes

Os professores da educação básica e a sua adesão a valores sociomorais:

uma investigação atual 37

Maria Suzana de Stefano Menin

Luciene R. P. Tognetta

Marialva Rossi Tavares

Patrícia U. R. Bataglia

Raul Aragão

Telma P. Vinha

Adriano Moro

Literatura infantojuvenil, visualidades e links: interações e leituras 49

Rodrigo da Costa Araujo

Fabiano Tadeu Grazioli

Rosemar Eurico Coenga

PARTE II As crianças e seu cotidiano: narrações sobre os fazeres pedagógicos na educação infantil

A influência do brincar abordado de maneira livre na educação infantil. 64

Kathiusa O'Hara Felipe

Peterson da Paz

Brincadeiras na escola de educação infantil: um estudo em Porto Velho/RO

Janís Hilário Barroso

Juracy Machado Pacífico

Memórias, experiências escolares e reflexão das práticas de leitura na educação infantil. 86

Denise Franco Dalla Rosa

Deusodete Rita da Silva Aimi 
Projetos didáticos na educação infantil: possibilidades concretas de trabalho interdisciplinar.. 96 Aline Zorzi Schultheis de Freitas Juracy Machado Pacífico

A formação social implícita nas possibilidades do faz-de-conta. 106 Marli Luiz Pereira Adriana L. de O. Rodrigues Josélia Gomes Neves 


\section{APRESENTAÇÃO}

Pensar as crianças, as infâncias e os espaços que habitam em uma sociedade pós-moderna tornou-se questão de primeira ordem. Não por uma questão de modismo ou de temporalidade, mas pela trajetória histórica percorrida e pela construção sociocultural da percepção de que as crianças, enquanto categoria social de análise, entremeada às outras categorias analíticas, nos permite compreender quais relações temos construído com as crianças e quais outras possibilidades de diálogo, de pensamento esse encontro pode provocar. Voltando o foco especialmente às instituições de Educação Infantil, a potência desse encontro pode acenar para outras percepções do tempo, do espaço, das relações adulto-criança, do fazer pedagógico, das didáticas, da escola.

Diferentes áreas têm contribuído para que novos olhares sejam lançados junto com as crianças sobre as infâncias, sobre as próprias crianças e, inclusive, sobre a educação das crianças, como a Antropologia, a Filosofia e com especial destaque, a Sociologia da Infância.

Promover outros diálogos entre a Pedagogia e a Educação tem sido o desafio lançado pelas próprias crianças, quando interrogam seu professor ou professora, com seus saberes, por vezes clandestinos, que rompem a fôrma/escola, que usurpam o tempo de produção para a anunciação de outros tempos de mundo e de palavra. Os discursos e as práticas são rechaçados por um corpo rebelde, transgressor, autêntico.

O caminho é longo. As pistas estarão nos próprios pés, na travessia, na travessura, no encantamento, na leveza e na força da palavra. As crianças já nos ensinaram isso. O atravessamento que corta as fronteiras, os cruzamentos, certamente recompensará a novidade da semana passada, anunciada pelas vozes silenciadas na história e no tempo.

Este livro tem a pretensão de provocar outras vozes, outros caminhos. Sua organização congrega, principalmente, resultados de trabalhos, estudos e reflexões que foram desenvolvidos durante o Curso de Especialização em Docência na 
Educação Infantil, realizado em parceria entre Ministério da Educação, Universidade Federal de Rondônia e União Nacional dos Dirigentes Municipais (UNDIME/RO).

Conforme Projeto Pedagógico do Curso (PPC) (UNIR, 2013), o mesmo, organizado em três eixos temáticas e nove disciplinas, trouxe como núcleo teórico e prático, a prática pedagógica da professora da Educação Infantil. Foi destinado especificamente para professoras no exercício da docência na Educação Infantil, com no mínimo três anos de experiência na etapa. O Eixo I - Fundamentos da Educação Infantil, estruturou-se em torno de duas referências:

[...] concepções de infância e a emergência da Educação Infantil nas políticas nacionais e municipais. O objetivo geral é compreender as relações entre as concepções de infância que perpassam a cultura e as políticas de educação das crianças de 0 a 6 anos. Focaliza as infâncias e as crianças dos diferentes grupos humanos como seres que se constituem em suas interações com os outros, com a natureza e com a diversidade de práticas culturais. Enfoca também a emergência da educação da criança pequena em espaços coletivos e as políticas públicas de educação infantil de âmbito nacional e local, tendo como referências documentos orientadores relevantes, como as Diretrizes Curriculares Nacionais da Educação Infantil (2009), entre outros, e levantamentos e estudos sobre a situação do atendimento nessa etapa educacional. (UNIR, 2013, p. 16).

Este eixo foi desenvolvido a partir da disciplina Infâncias e crianças na cultura contemporânea e nas políticas de Educação Infantil: diretrizes nacionais e contextos municipais. O Eixo II - Identidades, prática docente e pesquisa, eixo transversal, integrou os conteúdos de disciplinas, oficinas e seminários realizados ao longo do curso voltados aos problemas, ações e projetos vivenciados pelas cursistas nas instituições educativas. Constituiu-se como espaço privilegiado para:

[...] o desenvolvimento de atitude investigativa e reflexões sobre as experiências e práticas profissionais com crianças pequenas, em creches e pré-escolas, bem como suas famílias, o entorno e a população local. Nele são articulados temas como memória, pesquisa e intervenção na educação infantil. Focaliza as identidades pessoais, profissionais e institucionais e as possibilidades para ressignificação da ação docente. O eixo inclui a orientação dos cursistas na elaboração, implantação e avaliação de Plano de Ação Pedagógica e na elaboração de Trabalho de Conclusão de Curso. Essa orientação é desenvolvida no âmbito da disciplina Análise Crítica da Prática Pedagógica (ACPP). (UNIR, 2013, p. 16-17).

Este eixo foi desenvolvido a partir de três disciplinas: Metodologias de Pesquisa e educação infantil, Seminários de Pesquisa e Oficinas, Análise Crítica da Prática Pedagógica - ACPP.

O Eixo III: Cotidiano e ação pedagógica, teve o objetivo de

[...] contemplar a formação de professoras na educação infantil de forma a promover uma ação pedagógica sustentada na observação e escuta dos bebês e das crianças pequenas como referência para a prática educativa, considerando a diversidade, a implementação de uma prática educativa inclusiva, que tenha como eixos as interações e a brincadeira, as expressões infantis, a promoção da autonomia e da autoria das crianças de diferentes idades, bem como sua ampliação cultural. (UNIR, 2013, p. 17). 
O eixo consubstanciou-se em cinco disciplinas: Currículo, proposta pedagógica, planejamento e organização e gestão do espaço, do tempo e das rotinas em creches e pré-escolas, Brinquedos e brincadeiras no cotidiano da Educação Infantil, Linguagem, oralidade e cultura escrita, Expressão e arte na infância e Natureza e cultura: conhecimentos e saberes.

A partir das avaliações realizadas pelas cursistas e coordenadoras foi possível perceber o importante impacto que teve o curso na formação específica para a docência na Educação Infantil. No entanto, os relatos apontam para a necessidade de mais investimento na formação continuada de professoras para atuar na primeira etapa da Educação Básica, pois historicamente essa etapa e a formação para nela atuar têm sido temas à margem das políticas públicas. O programa foi, sem dúvida, enquanto projeto induzido pelo Ministério da Educação, uma política pública educacional imprescindível para o fortalecimento da identidade da Educação Infantil pela via da formação docente.

O livro, constituído neste contexto, apresenta resultados de pesquisas e reflexões, em sua maioria, de alunas, docentes e coordenadoras do curso. No entanto, também apresenta importantes contribuições de pesquisadores e pesquisadoras de outras instituições brasileiras. Foi organizado em dez capítulos que dialogam entre si em suas temáticas.

Iniciando a obra, e com discussão importante e contemporânea sobre a sociologia da infância, João Clemente de Souza Neto (UPM), no texto Aceno para uma sociologia da infância no Brasil, busca encontrar na matriz do pensamento brasileiro elementos para uma sociologia da infância. Destaca que a "temática nos remete ao século $X X$, quando os primeiros sociólogos, ainda que de forma tênue e opaca, ofereceram uma base para o que hoje denominamos de sociologia da infância". Aponta autoras que se neste campo, como Gilberto Freyre, nas obras Casa Grande e Senzala e Sobrados e Mucambos, e Florestan Fernandes com a obra "Folclore e mudança social na cidade de São Paulo", que, segundo o autor, são obras de caráter etnográfico e que nelas aparecem as primeiras observações que situam a infância como um fenômeno a ser estudado e pesquisado.

Também abordando especificamente as infâncias, no segundo capítulo desta obra Rosane Alonso Alves (UNIR) apresenta no texto Sobre as infâncias e o modo de ser das crianças, as discussões teóricas acerca da infância e da criança abordadas no Curso de Especialização em Docência na Educação Infantil, desenvolvidas a partir das discussões sobre a arte e expressão com as crianças de zero a cinco anos, que levou a aprofundar estudos sobre as concepções de culturas infantis inseridas nos espaços da Educação Infantil.

Discutindo as culturas infantis, Renata Aparecida Carbone Mizusaki (UNIR) e Cleomar Ferreira Gomes (UFMT), com o texto Corpos que brincam: ciranda do consumo e culturas infantis, investem em questões, o que pode a escola diante da imposição capitalista às crianças para que consumam cada vez mais e mais cedo? 
Por que consumir é tão necessário nos dias de hoje, e, em especial na infância? Enfatizam que a cultura ocidental, marcada por elementos que caracterizam a criança pós-moderna como indivíduo livre, capaz, sujeito de direitos, em condições de desenvolvimento, pensante, capaz de criar sua cultura, vê neste nicho infantil, mais do que um reconhecimento da criança que deixa de ser a sombra do adulto ou apenas uma parte mínima dele, tal como na Idade Média e até o século XVII.

No capítulo quatro, de autoria de Maria Suzana de Stefano Menin (UNESP), Luciene R. P. Tognetta (UNESP), Marialva Rossi Tavares (FCC), Patrícia U. R. Bataglia (UNESP), Raul Aragão(UNESP), Telma P. Vinha e Adriano Moro (UNICAMP), o texto Professores da educação básica e a sua adesão a valores sociomorais: uma investigação atual, trilhando pelo campo da psicologia educacional, apresenta uma pesquisa que teve como objetivo a construção de um instrumento capaz de avaliar a presença e o modo de adesão de crianças, jovens e seus professores, aos valores sociomorais de justiça, respeito, solidariedade e convivência democrática. A pesquisa desenvolvida contou com financiamento da Fundação Carlos Chagas e FAPESP, e neste texto são apresentadas as respostas e de professores da educação básica sobre os conceitos abordados na pesquisa.

No quinto capítulo desta obra, intitulado Literatura infantojuvenil, visualidades e links: interações e leituras, os autores Rodrigo da Costa Araujo (FAFIMA), Fabiano Tadeu Grazioli (URI) e Rosemar Eurico Coenga (UNIRONDON), discutem que a literatura e os livros infantojuvenis contemporâneos, apoiados em vários recursos da linguagem visual e no contexto da hipermídia, apresentam-se e propõem-se como lugares criativos de manifestação da experiência das imagens, sejam como ponto de confronto entre riscos do dizer e o que falam (ou escrevem) sobre o ver, ou como ponto de fricção e de interpretação de linguagens. Para autores, nessa operação de "ler" ilustrações, links e intertextos, portanto, implica a importância capital da imagem na cultura contemporânea e no design do livro infantil, por conseguinte, em critérios de leitura para desvendar suas discursividades e narratividades em potência pelos professores mediadores de leitura junto aos sujeitos leitores na infância e fora dela.

O capítulo 6, de autoria de Kathiusa O'Hara Felipe (Professora da Educação Infantil) e Peterson da Paz (UNIR), intitulado $A$ influência do brincar abordado de maneira livre na educação infantil, evidenciou a importância do brincar livremente na Educação Infantil no processo desenvolvimento e aprendizagem das crianças. Uma das autoras, aluna do curso, elaborou um projeto de intervenção que foi desenvolvido em uma sala de Pré II, com 24 alunos de uma escola municipal de Vilhena/RO, com crianças na faixa etária de 4 e 5 anos, em que foram desenvolvidas diversas brincadeiras com envolvimento de todas as crianças.

O capítulo 7, Brincadeiras na escola de Educação Infantil: um estudo em Porto Velho/RO, de autoria de Janís Hilário Barroso (Licenciada em Pedagogia/UNIR) e Juracy Machado Pacífico (UNIR), apresenta resultados de estudo que investigou a presença das brincadeiras na prática pedagógica da professora de Educação 
Infantil. Objetivou apreender de que forma a professora insere brincadeiras em seu planejamento. A partir de uma abordagem qualitativa, observou a prática pedagógica de uma professora de pré-escola e aplicou questionário para três professoras também de pré-escola. Os dados revelam que as brincadeiras, em seu sentido mais rico, dirigida ou livre, ainda estão longe da sala de aula e, de modo geral, das escolas públicas de Educação Infantil de Porto Velho.

Memórias, experiências escolares e reflexão sobre as práticas de leitura na Educação Infantil, de autoria de Denise Franco Dalla Rosa(professora da Educação Infantil), Deusodete Rita da Silva Aimi (UNIR) e oitavo capítulo da obra, apresenta memórias de uma das autoras sobre sua escolarização, além das primeiras experiências das autoras com a sala de aula no papel de ajudante e estagiária de instituições escolares, reflexões das práticas realizadas com as crianças/alunas, na condição de professora da Educação Infantil e, reflexões realizadas no desenvolvimento do projeto de intervenção Práticas de Leituras na Educação Infantil.

O texto Aprendendo a se alimentar na educação infantil: pressuposto para a qualidade de vida, de autoria de Aline Zorzi Schultheis de Freitas (IFAM) e Juracy Machado Pacífico (UNIR) apresenta algumas considerações sobre a infância e a educação infantil, relevantes para as práticas pedagógicas dessa etapa. O constituise em um relato de experiência sobre o projeto "Aprendendo a se alimentar na educação infantil: pressuposto para a qualidade de vida", desenvolvido com crianças de três anos de idade de uma escola municipal de Manaus, Amazonas. O objetivo do projeto foi desenvolver o hábito de consumir alimentos saudáveis e demonstrar como tal consumo contribui para a saúde. Ao narrar as experiências vivenciadas pelas crianças durante o projeto é possível observar como brincadeiras, jogos, música, artes visuais, atividades de movimento, entre outros fazem parte do processo de desenvolvimento na educação infantil. Ainda se evidencia como o trabalho com projetos contribui para a contextualização do ensino e a interdisciplinaridade.

O capítulo 10, A formação social implícita nas possibilidades do faz-de-conta, de autoria de Marli Luiz Pereira (Professora da Educação Infantil) e Adriana L. de O. Rodrigues (UNIR), apresenta parte das temáticas discutidas no Curso de Especialização em Docência na Educação Infantil (CEDEI), da Universidade Federal de Rondônia (UNIR), da turma desenvolvida no polo do Campus de Ji-Paraná-RO. As autoras destacam que o curso objetivou a promoção de mudanças no fazer pedagógico e, portanto, este aspecto foi considerado no desenvolvimento do projeto e, consequentemente, na elaboração desse texto. A partir das contribuições das disciplinas Análise Crítica da Prática Pedagógica - ACPP e Brinquedos e Brincadeira no Cotidiano da Educação Infantil, as autoras elaboraram um projeto de intervenção que priorizou a ludicidade na Educação Infantil. O projeto foi desenvolvido em escola de Educação Infantil no Município de Presidente Médici-RO, no último bimestre do ano de 2014 . 
Os leitores e leitoras perceberão que há uma grande diversidade nos estilos e as formas de escritas, o que propositadamente nos envereda para um olhar mais plural das relações com a escrita e com a palavra, visto que, como enfatiza Larrosa, é na palavra que nos construímos, que nos tornamos indivíduos e nos singularizamos. Estas escritas, singulares, trazem relatos de experiências de docentes, seus fazeres, seus saberes, suas iniciações e reinveinções junto com as crianças, algumas delas provocadas a partir do Curso de Especialização em Docência na Educação Infantil que, como já dito, oportunizou às docentes/alunas um atravessamento na/pela Educação Infantil, um exercício de pensar e possibilitar uma nova prática em Educação Infantil, com as crianças. Trazem também escritas de professores/pesquisadores que tentam desenhar novos caminhos para a escrita de uma história pelas pequenas e potentes mãos infantis. Uma incursão na originalidade, na criação. Uma descolonização. Outras linguagens do corpo, dos sentidos, do pensamento e das ideias. O convite está feito.

\author{
Juracy Machado Pacífico (UNIR) \\ Renata Aparecida Carbone Mizusaki (UNIR) \\ Sirley Leite Freitas(IFRO) \\ Josélia Gomes Neves (UNIR)
}


PARTE I. Contribuições aos estudos sobre as crianças e as infâncias: reflexões teóricas

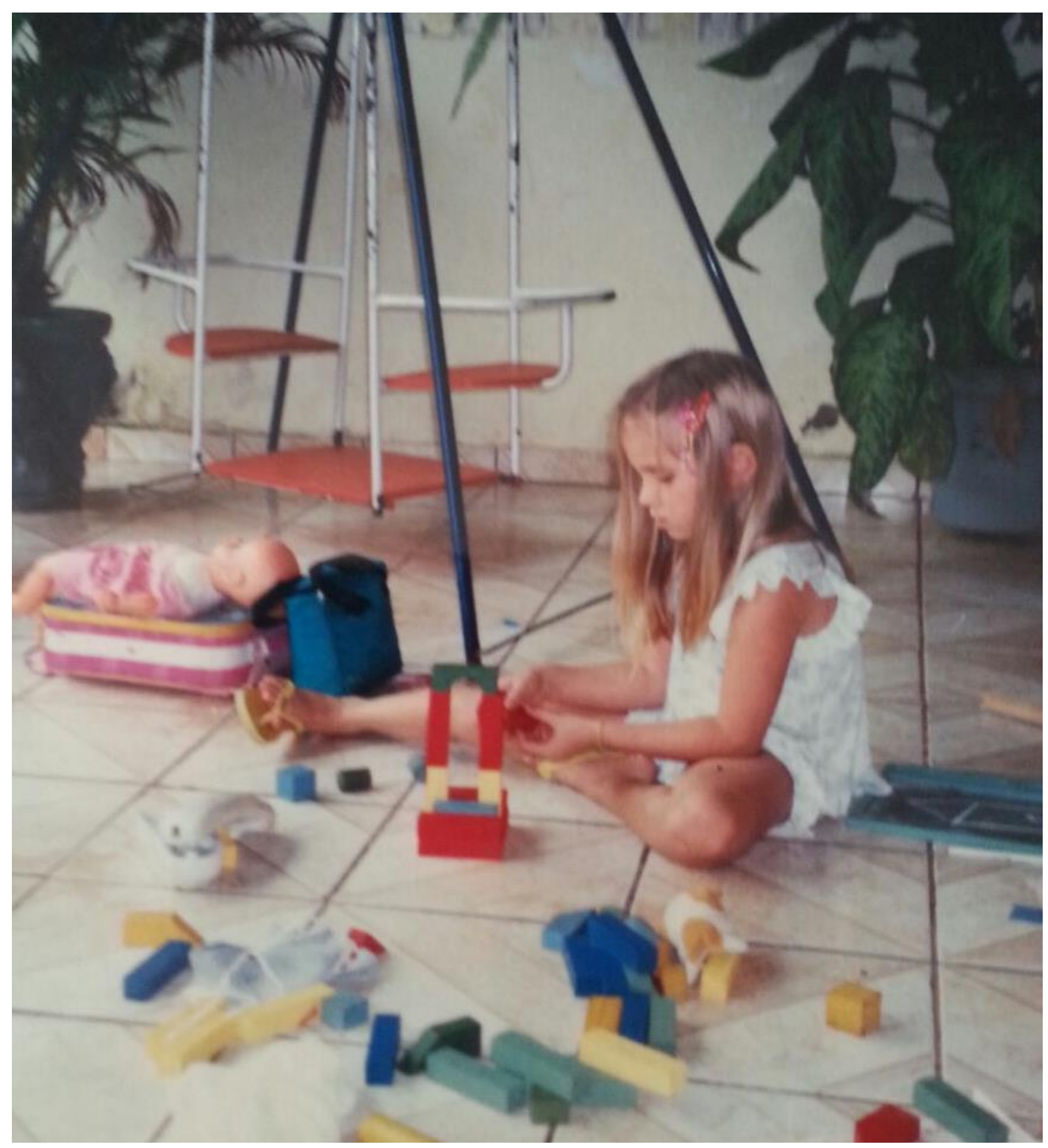

Foto: Juracy Pacífico 


\title{
Acenos para uma sociologia da infância no Brasil
}

\author{
João Clemente de Souza Neto
}

\section{Introdução}

O objetivo deste capítulo é encontrar na matriz do pensamento brasileiro elementos para uma sociologia da infância. Esta temática nos remete ao século $\mathrm{XX}$, quando os primeiros sociólogos, ainda que de forma tênue e opaca, ofereceram uma base para o que hoje denominamos de sociologia da infância. Neste campo, destacam-se Gilberto Freyre ("Casa Grande e Senzala", "Sobrados e Mucambos") e Florestan Fernandes ("Folclore e mudança social na cidade de São Paulo"), em cujas obras, de caráter etnográfico, aparecem as primeiras observações que situam a infância como um fenômeno a ser estudado e pesquisado.

Da visão da sociedade e do educador sobre a infância, dependem a prática, a didática e o fazer pedagógico, a forma de estabelecer e realizar os combinados com a criança, bem como a definição do lugar social da criança. Desvelar essa categoria significa compreender a sociedade e a educação. Cada criança, dependendo do seu grupo social, percorre todo um ritual de inserção social. Os primeiros pensadores brasileiros, de uma ou de outra forma, sempre se preocuparam em entender qual é o lugar da criança na sociedade brasileira e como ocorre o processo de socialização.

É desnecessário recordar que a criança sempre fez parte da sociedade, sempre colocada, porém, no campo da invisibilidade. Sensíveis para com a infância, pouco a pouco Florestan e Freyre a elegeram como uma categoria analítica que permite começar a elaborar uma sociologia específica. Eles descrevem o contexto da infância, de forma a oferecer informações complexas dentro de uma realidade heterogênea, na qual existem crianças em múltiplas situações, ligadas a condições raciais, econômicas e de gênero. Se não existe neles uma teoria da infância, há certamente apontamentos e indicativos para isso. 
No início da sociologia brasileira, os sociólogos tiveram resistência em seccionar a sociologia que, para eles, é o estudo dos fatos sociais totais. $\mathrm{Na}$ perspectiva de Mauss (2003), adotamos o objeto da sociologia como fato social total, sem fragmentações e separações. Mas entendemos que isso não nega a existência de fatos sociais específicos. Consideramos importante destacar que o fato social tem peculiaridades. Neste sentido, a infância é um fato social com transversalidade e singularidades.

As categorias analíticas são construções sociais da humanidade em busca da compreensão do real; são símbolos adquiridos historicamente. Freyre, por exemplo, faz uma análise na qual separa raça e cultura, e isto é importante em determinados momentos, mas ambas estão ligadas enquanto construção social. Ou seja, raça e cultura podem ser analisadas em paralelo, mas estão relacionadas a um mesmo ponto de convergência. Em síntese, queremos lembrar que o estudo da infância não pode ser feito de forma reducionista, mas em suas interfaces com os demais fenômenos sociais.

À medida que a sociedade se transforma, novas configurações e reconfigurações de convivência humana e aprendizado aparecem. É a vida social que altera sentidos e disposições. Uma coisa é pensar a vida social no Brasil colonial; outra coisa é pensá-la no contexto do trabalho escravo, no mundo rural, no urbano, no impacto da revolução industrial, na era da globalização. Neste cenário global, a categoria infância é simultaneamente singular e universal. Permite desvelar, compreender, construir e desconstruir o mundo, perceber o outro e reinventar as relações.

Pesquisar e atuar com a criança é um estímulo a percorrer um caminho rico de possibilidades de transformação e de construção do conhecimento, além de ser um convite à criatividade e ao acolhimento do novo. A sociologia da infância tende a ajudar a compreender a inserção e o papel da criança no mundo. A entrada de uma criança em cena produz uma nova configuração da família e do entorno. Esta forma de pensar a sociologia da infância encontramos no poema de João Cabral de Melo Neto.

Morte e Vida Severina retrata o desespero de um povo que anda passo a passo em busca de uma vida melhor, até descobrir que tanto faz viver quanto morrer. Em meio aos desafios e questionamentos que percorrem o decorrer da trama poética, um fato novo se impõe, pois a vida acontece. Num determinado momento, nasce uma criança e, por este fato, diz o autor, "cada casebre se torna no mocambo modelar que tanto celebram os sociólogos do lugar" (MELO NETO, 2000, p. 23). Só com o nascimento da criança é possível produzir um conhecimento que responda às indagações, sobretudo entre o viver e o morrer, entre o desespero e a esperança. E Cabral assinala em sua poética: 
fabrica, vê-la brotar como há pouco em nova vida explodida; mesmo quando é assim pequena a explosão, como a ocorrida; como a de há pouco, franzina; mesmo quando é a explosão de uma vida Severina (MELO NETO, 2000, p. 28).

Enquanto categoria, a infância é constituída de múltiplas vozes. Na cultura nordestina, aparece, às vezes, como uma voz de sofrimento e silêncio profundo. Por mais contraditório que pareça, por mais paradoxal, esse é um silêncio de esperança. É a teimosia da vida que chega para ocupar e descobrir o seu lugar. É a infância que mesmo contra toda a desesperança, é protagonista, porque tem uma voz diferente da voz dos adultos e nos ensina a viver, na sua linguagem terna e novidadeira.

Uma nova vida sempre traz respostas e novas questões. Cabe ressaltar que Freyre (1936; 1963) e Florestan (1986; 2004), nas descrições sobre a infância, têm por detrás uma novidade e uma nova forma de pensar e de organizar o mundo, mesmo que leve. Eles nos ajudam a tecer os múltiplos rostos da infância dos séculos XIX e XX no Brasil, assim como a dinâmica da educação, com suas propostas pedagógicas. Ao descrever o cotidiano infantil, apresentam, de forma analítica, a vida da comunidade e nos deixam perceber que não existe uma única infância, mas infâncias. Uma coisa é ser criança na casa grande, outra coisa na senzala; uma coisa é ser filho do homem livre, do capataz, do operário, do empresário ou do fazendeiro, outra coisa é ser filho do sem terra.

\section{Brincadeira e infância}

A educação infantil, como hoje a conhecemos, aparece em meados do século XX; também o ensino fundamental se desenvolve melhor nesse período, conforme prescrevem as Constituições brasileiras dessa época. A educação, porém, acontece nas diversas formas de relações humanas e não somente na escola. As crianças aprendem muito nas brincadeiras tradicionais e nas brincadeiras que elas mesmas inventavam, com recursos do próprio ambiente. Até meados do século $X X$, as crianças exploravam mais as ricas possibilidades da natureza.

\footnotetext{
Ao brincar, as crianças se educam e se preparam, literalmente, para a vida. Mesmo quando os temas ou as formas dos folguedos pareçam obsoletos, o substrato psicossocial das ações e das relações que eles envolvem pode trabalhar nessa direção. Outro ponto que não deixa de ser importante: as atividades sociais das crianças envolvem atitudes ou disposições mais ou menos complexas. A criança que empresta suas bolinhas ao parceiro, porque este procedeu dessa forma com ela ou porque considera uma dever agir desse modo, põe em prática um princípio altamente abstrato, que é o da reciprocidade (FERNANDES, 1986, p. 209).
}

Nas narrativas das brincadeiras, Florestan Fernandes vai demonstrando como a criança internaliza alguns valores e habilidades, tais como cooperação, 
solidariedade, respeito, capacidade de organizar, de interpretar e de desvendar o mundo. É seu modo de inserção no mundo, de aprender a lidar com as situações. A história multiplica os exemplos dos jeitos de ser criança, que vão da caça e coleta até a era da comunicação. Conforme a sociedade se modifica, novas formas de brincar e novos jeitos de conviver emergem. Esta possibilidade nós também encontramos nas obras de Gilberto Freyre.

Em nossos estudos da história, observamos que a noção de infância sempre esteve intimamente ligada ao sistema econômico e a suas repercussões nas estruturas familiares, culturais e institucionais. No cenário globalizado do século XXI, há diferentes tipos de infância, que oscilam entre ricos e pobres, orientais e ocidentais, brancos e negros, cristãos e não cristãos, na guerra e na paz. Atualmente, diversas implicações impedem a garantia da proteção e a liberdade da criança, apesar de termos recursos suficientes e suportes teóricos e jurídicos para garantir seu bem-estar. Quando observamos os indicadores sociais, percebemos o quanto as crianças são ainda massacradas. Quando uma sociedade não consegue proteger suas crianças, alguma coisa está errada.

A infância permite compreender a complexidade de uma organização societária. "A beleza da história da infância, por toda sua complexidade e por todas as discussões que suscita, é que ela fornece um roteiro para se saber de onde provém a experiência humana, enquanto se desloca rapidamente no presente em seu caminho do passado para o futuro." (STEARNS, 2006, p.212.) A privação dos direitos sociais da infância e da adolescência mostra a ausência de políticas sociais bem estabelecidas.

\section{Um olhar pelas janelas da história}

A história brasileira é um rico celeiro de elementos para compreendermos a infância e, ao mesmo tempo, para construirmos as bases de uma sociologia da infância. Os ordenamentos jurídicos, sobretudo o Estatuto da Criança e do Adolescente (ECA), a Lei de Diretrizes e Bases da Educação Nacional (LDBN) e a Política Nacional de Educação Infantil pressupõem proteção, cuidado, educação e protagonismo, elementos que corroboram uma sociologia da infância. Esta perspectiva tende a ver a infância como um feixe de potencialidades e não como um conjunto de carências e de impossibilidades. Crianças não são coisas e nem seres menores, mas sujeitos de direitos e em desenvolvimento.

Num rápido olhar para a história do Brasil, percebemos que crianças e coisas sempre foram tratadas do mesmo jeito, ao ponto de podermos afirmar que uma política de genocídio perpassa a história da população infanto-juvenil no país. No período colonial, além da morte de milhares de pequenos indígenas pela ação dos 
colonizadores que tentavam "domesticar" as tribos, a proposta jesuítica de atingir a tribo por meio da cristianização das crianças acabava por romper com as crenças oriundas de seus ancestrais. Para facilitar seus trabalhos, os jesuítas separavam crianças das tribos para residirem na "Casa do Muchacho", em Piratininga, na qual ficavam os órfãos e os filhos dos gentios.

Indígenas e crianças eram concebidos pela cultura dominante ou dos conquistadores como seres destituídos de vontade e desejos, talvez como "animais sem alma", de cuja existência se duvidava. Acreditavam os missionários trazer aos índios o benefício inestimável da "graça do batismo cristão". Na realidade, atendiam a uma das exigências da Coroa portuguesa, que ajudava a escamotear a exploração do trabalho indígena e das riquezas naturais da Colônia.

Na mentalidade da época, a puberdade marcava a passagem do "paraíso", da "inocência original" da infância, à idade perigosa do "conhecimento do bem e do mal". Por meio da catequese, os educadores tinham em mente manter a docilidade e a obediência da criança na idade adulta, induzindo-a, por essa forma, à negação de sua própria cultura. E qualquer resistência ao projeto de constituir, por essa forma, "[...] progenituras mais angélicas do que diabólicas" (PRIORE et al, 1991, p. 15) era considerada uma tentação demoníaca.

Provavelmente, a primeira legislação a favor dos direitos da criança foi a Lei do Ventre Livre, de 28 de setembro de 1871. Não podemos acreditar ingenuamente que essa lei salvaguardaria todos os direitos da criança libertada da escravidão. Mas iniciou um processo de libertação e essa é sua peculiar importância; em decorrência, porém, trouxe mais prejuízos do que benefícios à criança negra, pelo menos na época. "Na verdade, poucos acreditaram na sua eficácia para melhorar as condições de vida da criança no Brasil" (LIMA; VENÂNCIO apud SOUZA NETO, 2010, p. 76).

O enunciado da Lei do Ventre Livre obrigava os senhores a criar e cuidar das crianças libertas até completarem oito anos, quando eles poderiam receber do Estado a indenização de $600 \$ 000$ ou empregar gratuitamente os serviços do menor até os 21 anos de idade. Esse enunciado fazia da criança de oito anos um trabalhador, praticamente nas mesmas condições da escravidão.

Embora muitos autores afirmem que a maioria de crianças negras abandonadas que hoje perambulam pelos centros urbanos seja um resultado dessa lei, já em 1693, a administração do Rio de Janeiro pensava em formas de equacionar a questão do abandono da população infantil. Antônio Paes de Sande, governador da capitania, escrevia "[...] ao rei, 'deplorando a falta de caridade demonstrada em relação aos enjeitados', largados nas ruas e terrenos baldios" (LIMA; VENÂNCIO apud SOUZA NETO, 2010, p. 78). O número de crianças abandonadas nas praças, terrenos baldios e nas portas das igrejas era tão elevado que o orçamento só podia oferecer-Ihes uma assistência precária. 
Uma das soluções para o problema foi criar a Roda de Expostos nas Santas Casas de Misericórdia, seguindo a tradição portuguesa. A "roda" era um instrumento mecânico de forma cilíndrica que girava sobre o próprio eixo, compreendendo duas partes, uma voltada para o exterior e outra para o interior da Santa Casa. Notícias dos expostos encontram-se somente a partir do século XVII. As primeiras "rodas" foram instaladas em Salvador e no Rio de Janeiro, no século XVIII, o que caracteriza um problema urbano.

É difícil definir os motivos que levavam as mães ao abandono dos filhos, mas tudo faz crer que as razões eram principalmente de ordem moral, social e econômica. Na sociedade patriarcal brasileira, o adultério era um delito que recaía sobre a mulher e a criança. A deposição da criança na "roda" garantia o anonimato dos genitores. A doutrina cristã, no decorrer da história, consolidou o valor ético da família e condenou severamente o adultério, a ponto de o Direito Canônico não admitir a ordenação sacerdotal de um filho bastardo para o sacerdócio.

Enquanto a rejeição se resolvia pelo infanticídio nas sociedades primitivas, o abandono ou o confinamento em instituições de caridade era uma prática comum nas sociedades urbanas "civilizadas". As crianças abandonadas nas "rodas" eram, geralmente, filhas de mulheres livres brancas, em sua maioria. A criança ilegítima, pela moral da época, causava um escândalo social para as famílias nobres e para a mulher branca em geral, cuja honra devia ser preservada a qualquer custo.

O estigma de desonra ligado à mãe solteira era intimamente mais forte do que o estigma de ilegitimidade que o filho teria de suportar. Os negros livres não estavam tão condicionados aos preconceitos sociais da época, porém, mais na dependência de fatores econômicos. Um filho ilegítimo não desonrava a mulher negra como a branca. As crianças ilegítimas eram absorvidas pela família negra, na qual sempre cabia mais uma criança, desde que houvesse alimentação. Talvez isso explique por que tão poucas crianças de cor eram colocadas nas rodas.

Desde os tempos da Colônia, a exploração do trabalho da criança no Brasil se tornou uma realidade humilhante e vergonhosa. Durante o período escravocrata, as crianças escravas tinham que trabalhar no transporte de trouxas de roupas, tripés de tabuleiros e outros serviços, pois eram consideradas como instrumento de trabalho e fonte de renda, e sobre elas o pai e a mãe não tinham direitos. A condição degradante da criança sempre esteve historicamente relacionada à condição social e econômica da família.

A criança pobre podia ser alcunhada de preguiçosa, vadia, solta, desocupada, avessa ao trabalho ou viciada. A concepção que permeava as relações sociais e econômicas era da criança como adulto em miniatura, devendo viver de acordo com as pessoas que a circundavam. Não havia a percepção da criança como sujeito de direitos e nem a visão de que o trabalho pudesse afetar seu desenvolvimento. As atividades domésticas e outras eram vistas como formas de educação, o que justificava como natural o trabalho infantil. 
Frente à impossibilidade de frequentar a escola e jogadas ao deus-dará, milhares de crianças ficaram privadas da família, da educação e do carinho dos pais. Dessa situação para a prática de pequenos furtos e agressões era apenas um passo a mais. Cabe ressaltar, conforme destaca Freyre (1963, p. 457), que em nossa matriz cultural as meninas "[...] criadas em um ambiente rigorosamente patriarcal, viveram sob a mais dura tirania dos pais, substituída pela tirania dos maridos".

No Brasil do século $X X$, os grandes temas referentes à criança e ao adolescente foram problematizados no âmbito da lei. Entre eles, estão a erradicação do trabalho infantil, da mortalidade infantil, do analfabetismo e das doenças; o acesso à educação infantil, ao ensino fundamental, à vacinação e à alimentação; a desinstitucionalização, a criação de abrigos, os programas para adolescentes em conflito com a lei, o reconhecimento da paternidade e o direito à convivência familiar e comunitária. As legislações sociais, de lá até os dias de hoje, em algumas coisas avança, em outras recua, num jogo de forças em que foi construída a doutrina de proteção integral presente no ECA.

\section{Infância, sujeito em desenvolvimento}

Nossa preocupação é oferecer apontamentos para uma releitura da história da criança pela perspectiva de uma sociologia própria. O desafio que se coloca hoje no Brasil é perceber que não existe uma única infância e que, portanto, esta não é uma categoria homogênea, mas complexa, dotada de fisionomias que correspondem a realidades culturais e econômicas diferenciadas.

A política de educação infantil deve incorporar os conhecimentos da sociologia da infância no sentido de buscar novas práticas pedagógicas e libertar as práticas pedagógicas de patologias que acabam por psicologizar as relações entre crianças e adultos. O processo de aprendizagem e de socialização deve potencializar as brincadeiras, porque nelas as crianças encontram saídas, com a mediação de um bom educador. A nosso juízo, a criança é sujeito do processo de aprendizagem e de socialização. Ela não é um recipiente vazio, mas alguém capaz de receber e de dar sentido às coisas, de participar da construção de sua história. Os novos reordenamentos jurídicos brasileiros propiciam à criança essa condição.

Com base na perspectiva de Florestan Fernandes, entendemos que a sociologia da infância pode ajudar a produzir uma nova filosofia política e pedagógica, no sentido de construir o homem novo e a nova sociedade. O essencial é chegar a uma consciência libertadora do indivíduo e da sociedade, que repercuta nas relações entre crianças e adultos. 


\section{Referências}

FERNANDES, F. Coleção Os Grandes Cientistas Sociais. n. 58. São Paulo: Ática, 1986.

As trocinhas do Bom Retiro. São Paulo: Martins Fontes, 2004.

FREYRE, G. Sobrados e mucambos. São Paulo, Nacional, 1936.

Casa-grande e senzala. Brasília: UB, 1963.

MAUSS, M. Sociologia e antropologia. São Paulo: Cosac \& Naify, 2003.

MELO NETO, J. C. Morte e Vida Severina e outros poemas para vozes. Rio de Janeiro: Nova Fronteira, 2000.

PRIORE, M. D. et al. História da criança no Brasil. São Paulo: Contexto, 1991.

SOUZA NETO, J. C. de. A trajetória do menor a cidadão: filantropia, municipalização, políticas sociais. São Paulo: Expressão \& Arte, 2010.

STEARNS, P. N. A infância. São Paulo: Contexto, 2006. 


\section{Sobre as infâncias e o modo de ser das crianças ${ }^{1}$}

Rozane Alonso Alves

\section{Introdução}

A pretensão deste capítulo é problematizar as discussões teóricas acerca da infância, da criança. Discutir as concepções de culturas infantis inseridas nos espaços da Educação Infantil tornou-se necessário em função da problematização da arte e da expressão com as crianças de zero a cinco anos. Essas discussões se deram em função da disciplina intitulada: Expressão e Arte na Educação Infantil que ocorreu durante a Especialização em Docência na Educação Infantil. No entanto, este excerto se pautará em apresentar apenas as concepções apresentadas às professoras sobre as infâncias e os modos de ser criança na contemporaneidade, incluindo o espaço da escola.

\section{Cultura infantil: sobre a infância e a criança}

As crianças têm entendimento sobre as ações que a cercam a partir das vivências cotidianas estabelecidas pelo e no meio social que estão inseridas. Mesmo dentro de um processo histórico de luta pelos direitos das crianças não houve uma preocupação em saber delas, as suas necessidades, seus anseios e desejos. No entanto, as políticas de cuidado vieram favorecendo a produção de um espaço destinado às crianças.

\footnotetext{
${ }^{1}$ As discussões presente neste trabalho se deram em função da disciplina intitulada: Expressão e Arte na Educação Infantil que ocorreu durante a Especialização em Docência na Educação Infantil. As experiências apresentadas neste excerto se deram em quatro encontros realizados durante o ano de 2014.
} 
Demarcar a infância para separá-la e diferenciá-la da vida adulta, destinando às crianças uma função na sociedade - de aprendizes, especialmente - foi algo que aconteceu apenas entre os séculos XVII e $\mathrm{XVIII.} \mathrm{Antes} \mathrm{disso,} \mathrm{a} \mathrm{infância} \mathrm{denominava} \mathrm{e} \mathrm{abrangia} \mathrm{apenas} \mathrm{as} \mathrm{crianças}$ muito pequenas (DORNELLES; BUJES, 2012, p. 16).

Sobre o como se efetiva ou não os direitos das crianças de estarem presentes nas decisões da sua sociedade, concordo com Dornelles (2012, p. 53-36), quando discute e afirma:

Com a emergência da garantia de direitos dos grupos minoritários, as crianças também foram associadas a tais lutas contra a opressão e a desigualdade. Num processo gradativo, as crianças vão sendo contempladas com a garantia de cuidado e de proteção dos adultos, com os direitos de nome, nacionalidade e com o direito de brincar, para também o respeito pelas suas opiniões e participação. Essa projeção esta vinculada à nova implicação sobre (...) criança e infância como sujeitos ativos e categoria social. Tal reconhecimento marca o respeito e o exercício de seus direitos como meta primária na construção e implementação de políticas sociais.

Para tender um pouco em como se constitui a infância indígena em meio a historia da infância, busco apoio em Bujes (2010), quando ao retratar a infância a partir dos conceitos pós-críticos, traz à tona a discussão sobre os modos de governamento das crianças, de seus corpos, daí pensar que a infância não vem sendo abordada da forma como deveria ser, nem tão pouco visualizada no campo "pedagógico".

Nos parece, por um lado, é que tais notícias dão a impressão de ter como horizonte perdido de suas denúncias um tempo idílico, em que as coisas não teriam sido bem assim, um passado idealizado em que as crianças teriam sido respeitadas, amadas, cuidadas, atendidas em suas necessidades, um tempo em que teria florescido um desejável espírito de reverência de atenção e compromisso com esses pequenos seres. Algo assim como um lamento de perda de uma era de ouro da infância (DORNELLES; BUJES, 2012, p.12).

No entanto, Bujes (2010) ressalta que nos últimos tempos algumas pesquisas apontam para a reflexão da infância - da criança, enquanto sujeito que pensa e age sobre e com o meio social. Os conceitos propostos por Foucault no que se refere às relações de poder e governamento dos sujeitos, de suas vidas, no caso da infância, nos levam a pensar em como a sociedade foi encontrando meios para discipliná-las, em como torná-las produtivas. Daí a importância de se pensar na criança sob o não olhar adultocêntrico, de ver a criança como sujeito incompleto, como um adulto em miniatura. De pensar na infância enquanto formas de agir sobre as condutas dos outros (BUJES, 2002, p. 19).

Nos nossos contatos com as crianças e também quando tratamos delas, usualmente somos movidos por uma compreensão da infância como um dado atemporal. Uma visão da infância como dependência, com as crianças gradualmente conquistando sua autonomia intelectual e, por extensão, a sua autonomia moral; a infância como um momento privilegiado, que representa o que de mais puro e bom exista na sociedade [...]. 
É neste momento que elas - as crianças têm mais visibilidade enquanto corpos a serem governados. Toda essa visibilidade estava voltada ao disciplinamento "como forma de exercícios de dominação, como estratégia para extrair dos corpos vigiados e examinados o máximo de utilidade e obediência" (BUJES, 2002, p. 20). E neste sentido, segundo Bujes (2002), que as instituições voltadas para a infância começam, ter um olhar específico, no sentido de não apenas dar assistência, mas administrar a vida das crianças. A família começa a ganhar novas obrigações com a sociedade no que se refere à criação de seus filhos, especificamente com a saúde e moral.

À constituição de uma infância tida como universal, serve para produzir um sujeito único que tem suas próprias características. E são estas características que o torna diferente ao grupo social, criando um processo de normalização e ordenamento por meio de disciplinamento. Bujes (2010) evidencia outro fator como forma de gerir as crianças - o Biopoder, criando sobre a criança um "conceito de infância" que deve ser protegido do mundo adulto. $O$ biopoder se refere às práticas dos estados modernos para regulação e controle dos que dele, fazem parte, e dele ninguém escapa.

Revel (2005) assinala ainda que Foucault ao discorrer sobre o conceito e processo de regulação da população pelo estado moderno, buscou apontar a maneira como o biopoder

[...] tende a se transformar, entre o fim do século XVIII e o começo do século XIX, a fim de governar não somente os indivíduos por meio de um certo número de procedimentos disciplinares, mas o conjunto dos viventes constituídos em população: a biopolítica - por meio dos biopoderes locais se ocupará, portanto, da gestão da saúde, da higiene, da alimentação, da sexualidade, da natalidade etc., na medida em que elas se tornaram preocupações políticas (REVEL, 2005, p.26).

Tais preocupações aparecem nos estudos de Bujes (2010), quando aponta que a partir do século $\mathrm{XVI}$ há um novo olhar sobre a forma de governamento também das crianças. Este novo olhar aponta que o governar territórios não é a única e necessária forma/prática de governo, "a arte de governar" amplia-se e seus objetivos, passam a ser concebidos como "o governo de si, das almas e das condutas, das crianças, o governo do estado". Passa-se a dar importância ao como e não o que governar.

A partir deste olhar, as sociedades começaram a se organizar de diversas formas, a repensar valores, como no caso do cristianismo, onde o "homem e a existência terrena é que se apresentaram, então, como centro de interesses" (BUJES, 2010, p.162). Com todo esse novo modelo de organização social houve interesse em expandir geográfica, econômica e culturalmente a sociedade, especificamente a europeia. Essa expansão acabou gerando mudanças intensas nos modos de vida, como por exemplo, "as guerras e as epidemias, não que as guerras e epidemias tenham sido causadas pelas" substituições de modos de vida, 
mas por meio deste acontecerem "processos" de apodrecimento e crises alimentares (BUJES, 2010).

A partir destas crises, no final do século XVI foram criados "programas de assistência aos pobres". Neste programa, a intenção era de fornecer educação escolar e cuidados médicos as crianças pobres. Havia uma grande diferença entre a educação dada aos filhos dos pobres e as de classe média alta. Para os primeiros, os cuidados eram assistencial. Já para os segundos era de educação. Com o aumento da pobreza algumas iniciativas foram tomadas, tais como a privação de pobres nas cidades, entre outras.

Todas estas decisões estavam voltadas ao governamento da vida destes sujeitos. Desta forma, Bujes (2010) ressalta que foram estabelecidas as novas maneiras de "ordenar" as pessoas, não se utilizava, de certa forma a hierarquia, mas o conceito de diferenças - os diferentes, ou seja, "ordenar, supunha, antes de mais nada, medir, para poder estabelecer séries” (BUJES, 2010, p.164).

Ordenar a vida das crianças passava especialmente para as crianças pobres, em risco, serem colocadas em determinadas instituições. Neste caso, pensar na roda dos enjeitados sendo salvos pelo batismo, já não se fazia tanto sentido, era preciso estabelecer modos de assisti-las. Exemplo: enviá-las as escolas, arrumar empregos. É neste momento que elas - as crianças têm mais visibilidade enquanto corpos a serem governados e para ela se traçavam planos, pois,

\begin{abstract}
Nos seus inícios, o modo de ver a infância não diferia muito das visões dominantes que a seu respeito vigem na sociedade. Uma infância marcada especialmente pelo signo da diferença. As crianças vistas como desiguais, desprotegidas, exploradas, excluídas, nos extratos majoritários da população. Ou ainda, como diferentes porque inocentes, imaturas tanto do ponto de vista social quanto cognitivo, "seres em falta", cujo "outro" seria o adulto. Uma infância como passagem - um estado até certo ponto indesejável, impróprio, pouco confortável - cujas marcas diferenciadas/diferenciadoras precisavam, no plano individual, ser rapidamente superadas, apagadas, esquecidas. Crianças que dependiam inapelavelmente de proteção e da autoridade dos mais velhos para se aproximarem do ideal da realização humana: seres maduros, equilibrados, produtivos, centrados, coerentes, racionais, no controle de suas emoções. Adultos em fim (BUJES, 2007, p. 14).
\end{abstract}

Há em suspenso uma naturalização sobre o que é a infância, o que é ser criança e as relações que elas podem e estabelecem com o mundo, com o meio, com seus pares, com os outros. De certa forma, tornou-se confortável assumir uma única infância, uma criança única, universalizando-as. "Essas perspectivas de significar a infância estão de tal maneira naturalizadas que deixam pouco espaço para que percebamos outras formas de pensá-las" (BUJES; DORNELLES, 2012, p. 16). 


\section{Cultura infantil: outros modos de ser e viver}

A partir da historicidade da infância e os modos de perceber as crianças na sociedade, outros modos de ser e entender as crianças e produção das infâncias múltiplas, plurais, Bujes (2010) apresenta um modo de pensar a infância enquanto forma de agir sobre as condutas das crianças. Para entendermos melhor estes apontamentos, a autora propõe compreender a concepção de infância em risco - as crianças começam a serem vistas como necessitadas de proteção, a partir de uma análise histórica. Neste sentido, ressalta que mais do que analisar sua condição de vulnerabilidade social, é preciso entender como se constituem enquanto tal.

As crianças são afetas pelos modos de ser infantil hoje. Para Sarmento (2007, p.23),

As culturas da infância vivem do vai-vem das representações do mundo feitas pelas crianças em interação com as representações adultas dominantes. As duas culturas - as especificamente infantil e as da sociedade - que se conjugam na construção das culturas da infância, na variedade, pluralidade e até contradição que internamente informa uma e outra, referenciam o mundo de vida das crianças e enquadram a sua ação concreta.

O que se percebe nas discussões de Sarmento (2007) sobre as culturas infantis é a relação de uma interação com o mundo, com os sujeitos deste mundo. Para o autor, nas crianças "se enraíza numa concepção de pertença à sociedade global, como sujeito histórico, com características próprias, a quem são reconhecidos direitos de participação social” (SARMENTO, 2007, p. 23).

O autor ao discorrer sobre a "ação concreta de cada criança, nas condições sociais que produzem a possibilidade da sua constituição como sujeito e ator social", ressalta que as crianças são cotidianamente convidadas a fazer "uma bricolagem social" para garantirem a reprodução interpretativa das suas raízes culturais no quotidiano das suas existências" (SARMENTO, 2007, p. 26).

Volto a Sarmento quando afirma que:

Pela representação do outro, a criança incorpora, nos seus próprios traços, as linhas com que o outro inscreveu o mundo. Há peles que se desconhecem pela cor, nomes que se soletram a custo na estranheza das sílabas, medos se que esconjuram figurando o susto, hábitos e costumes que se estranham primeiro e depois se quotidianizam na repetição da sua aprendizagem. Há também uma ideia que se infiltra e se polariza em múltiplas direcções; a de que o outro é o mesmo de si e o mesmo um outro para o outro; e pelo diálogo do outro mesmo se aprende o mesmo a outrarse (SARMENTO, 2007, p. 33).

Essas ressignificações das crianças e de suas culturas infantis no espaço da escola e as relações que elas estabelecem com seus pares produzem interações entre si, incorporando, representando e recriando seus olhares infantis sobre o 
mundo, sobre si e sobre o outro. "A percepção do outro é realizada pelas crianças a partir do conjunto de expectativas que a sua inserção cultural lhes permite" (SARMENTO, 2007, p. 37). Não se admite como nos fala Dornelles (2005, p. 71) pensar uma infância universal, única,

[...] É preciso pelo menos que se leve em consideração que existem muitas outras infâncias. Existem infâncias mais pobres e mais ricas, infâncias do Terceiro Mundo e dos países mais ricos, infâncias da tecnologia e a dos buracos e esgotos, infâncias superprotegidas, abandonadas, socorridas, atendidas, desarmadas, amadas, armadas.

Ao levar em consideração as infâncias e os modos de viver e ser criança hoje, é preciso deixá-las participar dos espaços sociais, incluindo a escola e esta "participação exige um conjunto de condições para se efectivar, nomeadamente as características das crianças, as oportunidades educativas, assim como o próprio bem-estar das mesmas, entre outras" (TOMAS; GAMA, 2011, p. 8).

Os estudos sobre infâncias buscam a compreensão de novos conceitos, bem como a necessidade de desconstruir e reconstruir discursos enraizados sobre as crianças, tendo como propósito a reivindicação de seus direitos, uma vez que a participação das crianças no meio social ao qual elas estão inseridas ocorre por meio dos significados que elas criam e vivenciam nos mesmos. Neste caso, não só participam da sociedade como sujeito autônomo, mas, também os criam, recriam, o modificam e se modificam. Deste modo, as crianças:

[...] incorporam, interpretam e reconstroem continuamente informações culturais, constituídas por valores, normas sociais, ideais, crenças e representações sociais, frequentemente expressas sob a forma de histórias e narrativas, lendas, imagens, jogos, brinquedos e brincadeiras e outros artefatos culturais. A construção dos universos simbólicos das crianças é realizada na interação entre crianças e adultos e entre crianças e crianças e dela participam elementos culturais provenientes de círculos diferenciados de produção simbólica: a cultura da globalização [...] (SARMENTO, 2007, p.36).

Para Dornelles (2012, p. 85) "a infância é entendida como um tempo geracional, um tempo de sentido, de acontecimento e de experiência, em que a criança tem suas particularidades em relação a esses tempos e seus contextos". E a partir dessas particularidades que as crianças inserem em seus desenhos, em suas formas de ler, de ouvir de contar uma história, sua percepção de mundo, de vida, de ser e estar vivenciando determinados sentimentos, determinadas experiências.

\section{Considerações finais}

As possibilidades de experienciar junto às crianças outras infâncias são sempre possíveis aos educadores e educadoras. Essas possibilidades nos permitem 
ficar atentas e atentos às suas vozes, concepções de mundo, das relações que estabelecem com seus pares, com mundo, e até mesmo dentro e fora da escola. Ao nos permitir estar com elas, e vivenciar estas experiências nos aproximam deste mundo infantil, criando condições para que as crianças digam de si, sobre si e o outro, especificamente, como elas se veem e falam de si.

Esse modo de ser e se constitui enquanto sujeito criança-aluno, especificamente no espaço escolar tem significados diferentes, vivências e experiências diferentes. De algum modo, durante a disciplina supramencionada (vinculada ao Pós-Graduação Docência na Educação Infantil) podemos, ao menos, compreender, que as experiências infantis das crianças, suas marcas sociais, as permitem pensar sobre e o mundo. Estas experiências que tocam, que marcam, que deixam vestígios, efeitos (LARROSA, 2011) nos modos de ser das crianças (produzidas também no espaço da escola) as produzem. São representações sociais, pois são elas - as crianças, sujeitos sociais.

\section{Referências}

BUJES, M. I. E. Infância e maquinarias. Rio de Janeiro: DP\&A, 2002.

BUJES, M. I. Descaminhos. In: COSTA, M. V. (Org). Caminhos investigativos II: outros modos de pensar e fazer pesquisa em educação. Rio de Janeiro: Lamparina, 2007.

Infância e risco. Revista Educação e Realidade. Porto Alegre, v. 35, n. 3, p. 157-174, set./dez., 2010.

DORNELLES, L. V. Infâncias que nos escapam: da criança na rua à criança cyber. Petrópolis, RJ: Vozes, 2005.

Artefatos culturais: ciberinfâncias e crianças zappiens. In: DORNELLES, L. V., BUJES, M. I. E (Orgs). Educação e infância na era da informação. Porto Alegre: Mediação, 2012.

; BUJES, M.I.E. Alguns modos de significar a infância. In: DORNELLES, L.V., $\overline{B U J E S}, M . I . E$. (Orgs). Educação e infância na era da informação. Porto Alegre: Mediação, 2012.

LARROSA, J. Tecnologias do eu e educação. In: SILVA, T. T. da. (Org.) O sujeito da educação: estudos foucaultianos. 12a ed. Petrópolis, RJ: Vozes, 2011.

REVEL, J. Foucault: conceitos essenciais. São Carlos, SP: Claraluz, 2005.

SARMENTO, M. J. Culturas infantis e interculturalidade. In: DORNELLES (Org.) Produzindo pedagogias interculturais na infância. Petrópolis, RJ: Vozes, 2007. 
TOMAS, C.; GAMA, A. Cultura de (não) participação das crianças em contexto escolar. II Encontro de sociologia da educação: educação, territórios e (Des)lgualdades, 2011. 


\title{
Corpos que brincam: ciranda do consumo e culturas infantis
}

Renata Aparecida Carbone Mizusaki

Cleomar Ferreira Gomes

\section{Introdução}

\begin{abstract}
Assim deve ser, ao que parece, a lei da convivência: quanto mais incompreensível o mal, tanto mais encarniçada e grosseira é a luta contra ele (TCHEKHOV, 2007).
\end{abstract}

O que pode a escola diante da imposição capitalista às crianças para que consumam cada vez mais e mais cedo? Por que consumir é tão necessário nos dias de hoje, e, em especial na infância?

A cultura ocidental, marcada por elementos que caracterizam a criança pósmoderna como indivíduo livre, capaz, sujeito de direitos, em condições de desenvolvimento, pensante, capaz de criar sua cultura, vê neste nicho infantil, mais do que um reconhecimento da criança que deixa de ser a sombra do adulto ou apenas uma parte mínima dele, tal como na Idade Média e até o século XVII. Esse pequeno ser passa a ter uma parte importante na produção social, através do consumo de produtos, filmes, jogos, brinquedos e outros artefatos midiáticos/culturais que penetram o ambiente doméstico, substituindo os pais em suas funções de cuidar e educar em valores e em princípios e, suprindo também a escola, em seu currículo e práticas obsoletas, pouco atrativa.

Essa leitura compreensiva e dinâmica dos discursos, das práticas e das representações sobre a criança fornecem marcadores que apontam que o necessário encontro da Pedagogia e da educação deve acontecer no sentido de compreender a criança pós-moderna e a cultura infantil, num contexto real e cada vez mais violento. 
Esse jogo sutil e meticuloso de relações de poder criado por uma indústria midiática e corporativa tem seu próprio currículo. Esse "currículo corporativo" faz da cultura infantil uma cultura ávida pelo consumo. Numa linguagem sedutora, engendra a criança em seus discursos dando-lhes poder e autoridade frente ao adulto, na medida em que, abertamente discute assuntos, antes restritos ao mundo adulto, mas agora fácil e rapidamente disponível, de forma leve e estereotipada, agregando valores tradicionais capitalistas, os preconceitos de cor, raça, gênero, sobretudo cultural, em uma doce imagem em que a criança é empoderada.

Essas crianças-corpos que consumem, ainda que de forma não totalmente passiva, trazem inscritas em sua carne, uma modelagem sociocultural de comportamentos e ações que traduzem uma lógica imperialista, capitalista, consumista. Ser é ter. Ter o novo jogo, o novo brinquedo, ser como a personagem do novo filme, usar o que elas usam e consumir uma rede de aparatos que façam com que as crianças se identifiquem com seus(uas) ídolos(as) e com o lugar por eles(as) ocupados(as).

Neste cenário, o corpo infantil nada mais é do que um lugar de consumo ideológico em que as diferenças multiculturais deixam de existir; prevalece o padrão, a norma. Ocupam papel central nesta senda, entre corpo-consumidor e corpoindústria-cultura, pais e professores(as), cuja função é provocar, questionar, caminhar junto, ao lado, politizar o pensamento para que a criança possa, refletidamente, fazer suas opções, suas leituras e interpretações do mundo que a cerca. Construir outros corpos-possibilidades. Um atravessamento, sem fim, nem começo, mas na plenitude do meio, da inconformação, da inquietação de quem pensa. E é justamente essa inconformidade, essa violência que nos provoca a pensar. É este o exercício que nos propõe Kohan (2002).

O aprender está no meio do saber e do não saber. No meio. Para aprender há que se mover entre um e outro, sem ficar parado em nenhum dos dois. Aqueles que sabem e aqueles que não sabem não aprendem, não podem aprender. O aprender está no fluir do movimento do pensar, nos prisioneiros que continuam presos na imanência do interior da caverna e não naquele que se libertou para apreender a ideia transcendente. Aprender é uma velocidade, um movimento infinito e ilimitado. Mas não é o discurso da enormidade do saber humano nem a dualidade socrática que nos autoriza a descrevê-lo assim, pois não há deuses que saibam mais do que os seres humanos nem há nada que saber. Há, sim, a possibilidade de unir à diferença a diferença. É isso que significa aprender (KOHAN 2002, p. 129).

Se a escola não pode ensinar, ela pode provocar o movimento, o meio, a diferença. A escola pode outro corpo. A escola pode devir, (JÓDAR; GÓMEZ, 2002), isto é, consolidar-se num processo criativo e criador através do qual as minorias se metamorfoseiam e escapem do controle social, da ordem, do imposto, do calculado. Nesta possibilidade é o corpo que possibilita essa trajetória. Instaurar-se como um não-lugar, como uma metáfora da vida, como uma inconformação, um desenformamento que deseduca, que não se anestesia e nem se silencia. É uma carne viva, em carne, osso, veias e pensamentos, corpo-escola; escola-corpo. 
Assim, introduzir o devir-criança nas formas de pensar e viver a educação não é simplesmente promover um pensar, escrever, falar ou, em suma, educar "para" as crianças; segue-se disso, por um lado, que quem pensa, escreve, fala ou educa e, por outro, que quem recebe esse pensamento, essa escrita, fala ou educação não é, em nenhum dos dois casos, uma entidade prefixada de antemão e de uma vez por todas. Ao contrário, esse "para" é um processo em devir. Devir, duplamente e em paralelo, entre uns e outros, em direção à alteridade de ambos (JÓDAR, GÓMEZ, 2002, p. 3536).

\section{Descolonização do brincar: atravessamentos infantis}

A escola pode propor outros usos para o brincar, o brinquedo, para além do consumo e do capital. A escola pode outra experiência ${ }^{2}$ de brincar. De modo não pedagogizada ou psicologizante as brincadeiras e jogos na escola são oportunidades fundantes para o exercício libertador das crianças.

Conforme Gomes (2011), as brincadeiras e jogos enquanto expressão simbólica, visceral e mediadora da cultura infantil reverbera a liberdade e libertação das crianças através dos brinquedos. Ao brincar, a criança dinamiza a aprendizagem sobre uma cultura, reinterpretando seus significados culturais e sociais (BROUGĖRE, 1998), de modo divertido, leve, solto. Ao possibilitar o compartilhamento das brincadeiras, jogos e brinquedos com outras crianças, a riqueza do brincar se torna exponencial. Essa é a razão da escola provocar outro brincar; a socialização, o encontro de muitas crianças, de diferentes origens, crenças, valores, pertenças sociais, traduzem as múltiplas possibilidades do brincar, da experiência do brincar. No entanto, a lógica operante nas escolas tem sido a do silenciamento e da não liberdade. $O$ barulho, os corpos que juntos se amotinam, os espaços ocupados de diferentes formas fazem com que o controle seja partilhado e isso ressoa como afronta ao poder simbólico, onipresente e institucional da escola. Brincar torna-se, nessas vias, um ato subversivo, uma desterritorialização. $O$ rito escolar é profanado, pois esse mecanismo insolente que a criança usa para auto afirmar-se, colocar-se diante do mundo como humano que pensa, chamado brinquedo dá a criança a potência e a forma.

Essa ameaça tem sido contornada com a imposição de dias e horários específicos para que as crianças brinquem sob a supervisão do adulto, do(a) professor(a), capaz de trazer à normalidade qualquer corpo desviante.

Outro mecanismo de domesticação dos corpos é o direcionamento das brincadeiras por meio dos brinquedos de acordo com o gênero da criança. Carrinhos

\footnotetext{
${ }^{2}$ Experiência é utilizada aqui tal como se apresenta em Benjamin (1987), isto é, experiência como aquilo que nos impulsiona, que nos empurra, que nos toca profundamente de modo que esse afetar transforma toda a pobreza ou miséria em possibilidade, em recomeço de forma bárbara.
} 
para meninos e bonecas para as meninas. Esse "esquadrinhamento" minucioso que permeia as relações institucionais, mais do que determinar com qual tipo de brinquedo a criança pode brincar, está dizendo à ela quem ela deve ser, como deve se comportar, que lugar institucional e social ela ocupa. Vianna e Finco (2009), Louro (2003), Auad (s.d), têm dito que mesmo a escola sendo um espaço de convivência coletiva, que reúne no mesmo agrupamento meninos e meninas, não faz desse um lugar de convívio, de viver junto, viver com. Ao contrário, esses corpos-crianças devem viver rigorosamente sob a égide da dinâmica escolar que tem tratado de estereotipar de modo incisivo as identidades infantis, conformando-as e submetendo-as a um conjunto de valores e convenções sociais que não refletem os desejos, as desfronteirizações necessárias para a vivência plena de si.

No entanto, mesmo sem ser ensinada pela escola, a criança tem suas formas de resistir, de se desenformar. Esse exercício tenso, doloroso tem sido capturado pela escola como rebeldia, desordem, como doença a ser medicalizada. O corpo tem que ser silenciado, amansado.

O corpo carrega, portanto, historicidade vivida, reinterpretada. A respeito disso, Arroyo (2012) tem provocado questionamentos que acenam para outras relações/possibilidades para o corpo-escola. Ao conceber que os corpos que chegam a escola, cada vez mais sofridos, mais marginalizados, trazem inscritos em si uma experimentação social e cultural de segregação, de anulação e aniquilamento da potência de vida, que denotam uma autodidática construída no vivido, consolidada na vida cotidiana. Para esse autor, esses corpos buscam outras respostas da escola: questionam sobre os recortes sociais que os constroem, que Ihes dão aqueles contornos, aquelas marcas. Esses questionamentos, esses corpos, essas crianças, exigem da escola outros valores, outras ordens, outros corposescola. Pensar outra ética exige assim uma revisão profunda dos fundamentos e mecanismos institucionais, que questionem as armadilhas, as ideologias e a lógica do consumo, do capital, da mercadologização dos corpos, das infâncias, das crianças.

A afirmação de outra ética profissional que inspire novos tratos dessas infâncias-adolescências exige outros valores. Exige sua construção como tarefa da teoria pedagógica. Os valores não pairam no ar, mas se constroem em processos de deliberação individual e coletiva. Na medida em que avancemos no conhecimento dessas complexas vivências dos(as) educandos(as) e formos inventando novas relações e interações estaremos construindo novos valores coletivos e nova ética profissional (ARROYO, 2012, p. 43). 


\section{Considerações finais}

As crianças, esses corpos-crianças-história, impõem uma outra experiência de escola. Uma experiência de conhecimento, de possibilidades, de reinvenção de si e do mundo.

Kohan (2008), convida ao pensamento sobre a possibilidade desse imperioso encontro. Enveredando pela amizade, esse autor, num rigoroso exercício filosófico, defende que ao compreender o outro em sua singularidade e essência e na amizade pelo/com o outro, sentindo com ele, a relação criança-escola pode ter outras cenas, outros atravessamentos.

A amizade envolve, portanto, estar junto, ouvir, caminhar ao lado. Crianças e professores(as) estão profundamente ligados pela relação ensinar e aprender e essa amizade a qual Kohan (2008) refere-se, constrói-se, somente se, como afirma Hillman (s.d) for "vista com os olhos do coração", se houver uma beleza nesse encontro. Essa experiência reveladora pode aparelhar a criança para o entendimento de seu contexto social, para uma leitura de mundo, da vida, dos sentidos implícitos nos brinquedos fabricados para fabricar crianças, consumidores.

Isso implica, como assevera Larrosa (2002) outra relação com o tempo e com o conhecimento. A escola tem mantido uma relação capitalista com o tempo, cada vez produzir mais em menos tempo, o que impede a possibilidade de construção do pensamento e da experiência; da memória da experiência. $O$ "cultivo da arte do encontro" como aponta Larrosa (2002), se perde e se deixa passar a possibilidade da criança ser sujeito da experiência. O conhecimento, da mesma forma, não permite 0 perigo da travessia, do confronto com o inesperado, não provoca 0 pensamento, "os sentidos e os não sentidos" (LARROSA, 2002, p. 20).

Cultivar o encontro, os atravessamentos e os meios. Possibilidades de encantar-se com o conhecimento, com outras culturas, outros saberes infantis e outras infâncias. Pensar que o tempo áion, (Kohan, 2005), pode inscrever uma nova lógica e uma nova política do pensamento com as crianças, com os corpos-criançasculturas.

Compreender as bases da cultura em que se insere a criança, juntamente com outras categorias sociais, como raça, etnia, relações de gênero, geracionalidade, entre muitos outros, coloca em evidencia a premente demanda de diálogo, afeto, segurança e presença de adultos para com as crianças que hoje, estão vulneráveis e fragilizadas diante das imposições da cultura e do currículo corporativo que veem neste nicho fonte de lucro, dominação cultural e de poder. Estão aqui postos os desafios para as escolas, pais e sociedade: buscar outras brincadeiras, outros usos dos brinquedos, outros tempos e outros conhecimentos para a compreensão das infâncias pós-modernas e suas culturas infantis. 


\section{Referências}

ARROYO, M. Corpos precarizados que interrogam nossa ética profissional. In: ARROYO, M. G. SILVA da, M. R. (Orgs.) Corpo-infância: exercícios tensos de ser criança; por outras pedagogias dos corpos. Petrópolis (RJ): Vozes, 2012, p. 2354.

AUAD, D. Relações de gênero nas práticas escolares e a construção de um projeto de co-educação. FEUSP - GE: Gênero, Sexualidade e Educação/n.23 Disponível em: <www.anped.org.br/reuniões/27/ge23/z233.pdf>. Acesso em 20 abr. 2012.

BROGĖRE, G. A criança e a cultura lúdica. Revista da Faculdade de Educação. São Paulo: v.24, n. 2, 1998, s.p.

GOMES, C. F. O corpo silenciado na escola: notas etnográficas sobre sua linguagem lúdica. Revista ConnectiOn Line, v. 08, 2011, p. 1-11.

HILLMAN, J. Ensinar, aprender e educar. Mimeo. (s.d).

JÓDAR, F.; GÓMEZ, L. Devir-criança: experimentar e explorar outra educação. Revista Educação e Realidade. Porto Alegre, n. 27, v. 2, jul/dez 2002, p. 31-45.

KOHAN, W. O. Entre Deleuze e a educação: notas para uma política do pensamento. Revista Educação e Realidade. Porto Alegre, n. 27, v. 2, jul/dez 2002, p. 123-130.

KOHAN, W. O. Infância. Entre educação e filosofia. Belo Horizonte. Editora Autêntica, 2005.

KOHAN, W. O. Infância e Filosofia. In: SARMENTO, M.J.; GOUVEA, M.C.S. de. (Orgs.) Estudos de Infância: educação e práticas sociais. Petrópolis (RJ): Vozes, 2008, p. 40-61.

LARROSA, J. Notas sobre a experiência e o saber de experiência. Revista Brasileira de Educação. Rio de Janeiro: n. 19, jan/fev/mar/abr 2002, p.20-28.

LOURO, G. L. (Org.). O corpo educado: pedagogia da sexualidade. Petrópolis: Editora Vozes, 2003.

TCHEKHOV, A.P. Em casa. In:___. Um homem extraordinário e outras histórias. Porto Alegre:L\&PM, 2007, p. 39-49.

VIANA, C.; FINCO, D. Meninas e meninos na Educação Infantil: uma questão de gênero e poder. Cadernos Pagu, 33, jul/dez 2009, p. 265-283. 
Os professores da educação básica e a sua adesão a valores sociomorais: uma investigação atual ${ }^{3}$

\author{
Maria Suzana de Stefano Menin \\ Luciene R. P. Tognetta \\ Marialva Rossi Tavares \\ Patrícia U. R. Bataglia \\ Raul Aragão \\ Telma P. Vinha \\ Adriano Moro
}

\title{
Introdução
}

Entendemos valores como atribuições realizadas por sujeitos sociais sobre propriedades de objetos, sejam estes naturais ou produtos humanos. Os valores morais se relacionam aos atos ou produtos humanos e incluem ações realizadas consciente e livremente, ou seja, às quais se pode atribuir uma responsabilidade moral (VAZQUEZ, 1993). Como produções humanas, valores são construções históricas e mostram-se relativos às diferentes épocas e culturas. Nesse campo, pode-se ter um relativismo antropológico (LA TAILLE, 2006). No entanto, nesta pesquisa, interessamo-nos pelo modo como as pessoas se apropriam dos valores que já existem em sua cultura. Estes modos de adesão se mostram, dentro da Psicologia do Desenvolvimento, numa evolução que vai de uma forma mais primitiva, ou heterônoma, de assunção de valores, à outra forma mais elaborada e melhor, porque demonstra um modo mais autônomo de adesão e a conservação do valor em jogo. Segundo Piaget (1977) há, no desenvolvimento moral, duas tendências que se sobressaem - heteronomia e autonomia - e, somente nesta última, as pessoas aderem, de forma refletida, independente e voluntária, a valores mais universais; isto é, que buscam como fim maior, a afirmação da dignidade de toda e qualquer pessoa.

\footnotetext{
${ }^{3}$ Financiamento: Fundação Carlos Chagas e FAPESP.
} 
Uma das motivações para esta pesquisa reside no que tanto leigos, como teóricos, têm chamado de "crise de valores" (LIPOVETSKY, 2010; BAUMAN, 1998; JARES, 2005; LA TAILLE, MENIN, 2009). Essa "crise" pode ser entendida como a ausência de claros valores sociomorais que sirvam de guia para as pessoas escolherem metas para suas vidas e, mesmo, relacionarem-se com os outros em sociedade. La Taille (2009) discute essa ideia quando aponta que vivemos uma cultura do tédio e da vaidade. Tédio, pois faltariam sentidos claros para a vida; vaidade pela predominância atual de valores ligados à aparência sobre outros antes mais acreditados. Portanto, se não estivermos convencidos de que há uma crise de valores, teremos que ao menos reiterar o quanto valores como a justiça, a convivência democrática, o respeito, a solidariedade, estão em crise.

A escola não escapa dessa crise. Pelo contrário, a chamada "falta de respeito" dos alunos é uma das queixas mais frequente entre professores. Sabe-se que a maior dificuldade apontada por professores e agentes escolares no exercício de suas práticas são a indisciplina, a incivilidade e a violência dos alunos, num ambiente onde o desrespeito parece imperar e poucos sabem como agir na direção de uma educação moral bem sucedida (ZECHI, 2008; SPÓSITO, 2001; MENIN, et al 2010; TOGNETTA et al, 2010).

Os professores, então, se vêm, cada vez mais, com a incumbência de educarem moralmente seus alunos, mesmo que apontem essa tarefa como própria das famílias que falham em exercê-la (TREVISOL, 2009; TOGNETTA et al, 2010). No entanto, frequentemente, sentem-se mal preparados para enfrentar esse desafio; seja porque nunca tiveram formação para isso, seja porque a escola e os processos de ensino, por sua estrutura e organização atual, dificilmente oferecem oportunidades de reflexão sobre valores (VINHA, 2000; TOGNETTA; VINHA, 2007; MENIN; BATAGLIA; ZECHI, 2013).

Em pesquisa realizada junto a escolas públicas de diferentes regiões do Brasil sobre projetos bem sucedidos em educação moral, ou em valores, embora tenhamos obtido cerca de 1100 projetos descritos, menos de $2 \%$ deles puderam ser considerados como mais completos. Os projetos mostraram-se, em sua maioria, como tarefas disciplinares; resumiram-se em transmissão verbal de valores; originaram-se de iniciativas isoladas de certos professores; e não mantiveram coerência entre o que se pretendia ensinar e a forma e qualidade das relações sociais na escola. Além disso, em poucos projetos houve um preparo dos professores para a educação em valores. (MENIN; BATAGLIA; ZECHI, 2013).

Assim, embora a escola ensine valores sociomorais o tempo todo, o faz de modo irrefletido, baseando-se nas impressões que cada um traz de suas experiências anteriores de vida, deixando a educação moral a cargo das preferências e inclinações de cada agente escolar e que podem, até, ser antagônicas entre si. 
No Brasil, após um período de ditadura militar, quando se deixou de oferecer a chamada disciplina de Educação Moral e Cívica, houve um vazio em termos de educação moral nas escolas. Após mais de uma década, em 1997, os Parâmetros Curriculares Nacionais (BRASIL, 1997) foram apresentados às escolas brasileiras e estes colocaram a Ética como um dos temas transversais na Educação. Ao fazer isso, os valores de respeito mútuo, justiça, solidariedade e diálogo foram escolhidos como os mais importantes para o desenvolvimento moral e ético de crianças e adolescentes.

Desta forma, escolhemos, como foco desta pesquisa, os mesmos valores apontados como centrais pelos PCNs: justiça, solidariedade, respeito; e, em vez apenas do diálogo, definimos como convivência democrática o uso do diálogo em situações de conflito envolvendo um coletivo. A partir de tais valores, nos propusemos a elaborar uma escala que permitisse verificar a adesão a eles, tanto em professores, como em outras populações, e que permitisse a comparação entre populações que se queira investigar.

Há, na Psicologia, diferentes formas de medida de valores morais, principalmente ligadas à avaliação do julgamento moral e que são consagradas como instrumentos competentes, como os testes baseados nos dilemas morais e originados nas entrevistas de Kohlberg (1992) e seus seguidores (KOLLER, et al 1994; LIND, 2000; REST, 1986). No entanto, buscamos criar um instrumento voltado a questões da atualidade, aos contextos brasileiros, e que englobe a investigação dos quatro valores simultaneamente.

Desde Piaget (1977) surgem pesquisas sobre a forma dos julgamentos morais e a presença de valores nos julgamentos. Esse autor, através do uso de histórias fictícias que envolviam ações de crianças, investigou as noções de justiça imanente, distributiva e retributiva; a importância do princípio de igualdade da justiça distributiva quando comparada à obediência a autoridades; a escolha por sanções expiatórias ou de reciprocidade, e muitas outras noções infantis que envolviam o uso de valores tais como a igualdade, a justiça, a reciprocidade, a cooperação, solidariedade.

Kohlberg (1992), dando prosseguimento aos estudos de Piaget, usou dilemas morais para investigar o que chamou de níveis de raciocínio moral. Os dilemas eram histórias fictícias nas quais dois ou mais valores morais, ou um valor moral e outro legal, se contrapunham e era necessário decidir por um deles. Para definir os níveis de julgamento moral - pré-convencional, convencional e pós-convencional, esse autor considerou diversos componentes, como: a presença de valores que se confrontavam (amor $X$ justiça; obediência à lei $X$ respeito à vida; obediência à autoridade $X$ liberdade de expressão, e outros), a presença e intensidade de operações de justiça (justiça retributiva, distributiva, processual), e níveis de perspectiva social a partir da qual o sujeito construía seus argumentos. O autor destaca três perspectivas: uma perspectiva individualista ou egocentrada; outra 
centrada nas normas familiares e sociais ou sociocêntricas; e, finalmente, uma perspectiva moral, propriamente dita, mais avançada, baseada em contratos e procedimentos democráticos e princípios universalizáveis.

Em decorrência desse trabalho de Kohlberg (1992), bastante conhecido e reproduzido em várias aplicações e pesquisas interculturais, desenvolveram-se outros testes de medida de julgamento ou raciocínio moral, como o "Moral Judgement Interviw (MIJ)", o "Sociomoral Reflection Objective Measure (SROM) e o "Defining Issues Test (DIT), todos descritos em Koller e colaboradores (1994). Esses testes têm sido utilizados no Brasil e correlacionados com variáveis como classe social, escolas públicas e particulares, idades, gênero, regiões de pertinência (BIAGGIO, 1997; 2002).

No entanto, há problemas na aplicação desses testes em nossos contextos. Shimizu (2004) e Shimizu e Urano (2004), analisando a validação dos testes no Brasil, discutiu que o desempenho dos respondentes pode ser influenciado por aspectos relacionados à habilidade de leitura, à dificuldade de assimilação de certos conteúdos dos testes não adaptados à nossa cultura e ao formato não familiar das questões propostas. Assim, seria necessária, ainda, uma adaptação maior dos testes à cultura brasileira. É preciso adequá-los a nossa realidade, transformando os dilemas em situações mais próximas do cotidiano e dos problemas e conflitos que enfrentamos na atualidade.

Finalmente, destacamos que certas pesquisas dentro de uma perspectiva construtivista têm identificado o papel do contexto nos modos de raciocínio moral. Selman (1980) e Selman et al. (1986) identificam cinco estágios de entendimento interpessoal que descrevem como as crianças formam juízos dos outros e agem. Os estágios vão do egocentrismo acentuado, passando por níveis de descentração de perspectiva social e chegam a um sistema social e convencional de perspectivas. Para esses autores, uma criança pode mostrar uma estratégia mais evoluída numa situação e outra estratégia, menos avançada, em outro momento, em função das possibilidades e exigências do contexto. Assim, ao mesurar valores, é importante considerar como eles são percebidos pelos sujeitos frente ao contexto em que vivem; por exemplo, quando confrontados com valores oponentes - ou contravalores, ou quando apresentados em diferentes espaços sociais.

No Brasil, vários autores vêm estudando a manifestação de valores morais em crianças e adolescentes e os modos de sua adesão, como, por exemplo, La Taille (2006), Tognetta (2009), Vinha (2003), Menin (2002; 2007), Menin; Bataglia; Moro (2013). No entanto, poucos trabalhos pesquisam a adesão a mais de um valor simultaneamente, e dedicam-se a investigar professores.

Dessa forma, dando prosseguimento aos estudos sobre moralidade na Psicologia do Desenvolvimento, a presente pesquisa teve como objetivo a construção de um instrumento capaz de avaliar a presença e o modo de adesão de crianças, jovens, e seus professores, aos valores sociomorais de justiça, respeito, 
solidariedade e convivência democrática. Neste texto, apresentamos as respostas dos professores de educação básica que responderam o instrumento de pesquisa.

\section{Metodologia}

Como primeira etapa da pesquisa, construímos uma Matriz de referência com a definição e os diversos componentes, nomeados descritores, dos valores de justiça, respeito, solidariedade e convivência democrática. A Matriz foi inspirada nos PCNs (BRASIL, 1997) e em autores da Psicologia do desenvolvimento. Para cada valor, foram também pensados contra-valores, isto é, atitudes que são contrárias à adesão a cada valor.

Ilustramos, a seguir, uma parte da Matriz elaborada para o valor de justiça:

A justiça é composta dos princípios de igualdade e equidade e articula-se com outros valores morais, como a dignidade, o respeito, o diálogo. $\mathrm{O}$ princípio da igualdade é fundamental na justiça distributiva, para estabelecer critérios de atribuição de direitos e de deveres entre todas as pessoas. O mesmo ocorre na justiça retributiva em relação à atribuição de penalidades aos atos injustos, desrespeitosos e relativos às infrações.

Exemplo de descritores:

1. Afirmar e valorizar os princípios de justiça, tanto de igualdade como de equidade, para refletir, compreender, construir e aplicar regras, normas ou leis.

2. Identificar e repudiar situações (na família, na escola, nas mídias, na sociedade em geral e no meio ambiente) em que ocorram desigualdades, discriminações, preconceitos, incluídas ou não em situações de diversidade social.

3. Identificar e repudiar situações em que haja favorecimento de uns em prejuízo de outros resultantes de desrespeito a direitos ou de tratamento desigual.

Exemplo de contra-valores: Desigualdade; Discriminação; Individualismo; Autoritarismo. (Fonte: pesquisa dos autores; 2015).

Os itens (cerca de 120) foram construídos na forma de situações-problema e se basearam em cenas do cotidiano que poderiam ocorrem em quatro diferentes espaços: família, ambientes sociais diversos, escola e internet. As histórias terminavam com uma frase a completar ou uma questão sobre o que se deveria fazer e eram seguidas de cinco alternativas. O respondente deveria ler o item e escolher uma dentre as alternativas. Três delas apresentavam-se favoráveis ao valor focalizado (pró-valor, $\mathrm{P}$ ) e duas apresentavam-se contrárias a ele; ou seja, eram contra-valor (C). 
As alternativas também apresentaram três diferentes modos de adesão ao valor, entendidos como níveis de diferentes perspectivas sociais. Elas foram inspiradas num dos critérios para a definição dos níveis e estágios de julgamento sociomoral de Kohlberg (1992): pré-convencional, convencional, pós-convencional.

Como perspectiva social, ou percepção social, Kohlberg (1992, p. 186) define "[...] como as pessoas veem as outras, interpretam seus pensamentos e sentimentos e consideram o papel e o lugar que ocupam em sociedade". O autor ainda sublinha que "[...] o desenvolvimento da percepção social de um estágio, ocorre antes, ou é mais fácil que o desenvolvimento do estágio paralelo de juízo moral" (KOHLBERG, 1992, p. 186).

Nas alternativas de cada item construído, destacamos, respectivamente, uma perspectiva individualista ou egocentrada; outra centrada nas relações grupais, familiares e em normas sociais mais convencionais, nomeada sociocêntrica; e, finalmente, outra perspectiva, nomeada como moral, mais descentrada socialmente, baseada em contratos estabelecidos democraticamente através de procedimentos justos e em princípios considerados "universalizáveis" Como dissemos, no item, em função dessas perspectivas sociais, colocamos sempre cinco alternativas; três em que o valor focado foi afirmado, sendo, cada uma, num dos níveis de perspectiva social (P1, P2 e P3); e duas alternativas que afirmavam o contra-valor correspondente, sendo uma delas em perspectiva egocêntrica e outra em perspectiva sociocêntrica (C1 e C2).

Mostramos a seguir um exemplo de um item no valor de respeito cujas alternativas são apresentadas numa evolução dos contra-valores aos pró-valores nas diferentes perspectivas sociais:

Uma mãe tem uma filha, Lúcia, de 12 anos, e um filho, Daniel, de 10 anos. A mãe sempre pede mais ajuda para Lúcia nos serviços de casa, e em tarefas como: lavar louça, varrer o chão, colocar o lixo para fora; pois ela é mulher. Para Daniel, a mãe pede, às vezes, para fazer alguma compra no supermercado ou levar o cachorro para passear. Lúcia anda reclamando dessa divisão de tarefas. Então a mãe deveria...

C1 - deixar as tarefas de casa mais com Lúcia, pois fica mais fácil para a mãe ter a ajuda de uma mulher.

C2 - deixar as tarefas de casa com Lúcia, pois é quase uma regra que as mulheres façam essas coisas.

P1 - dividir igualmente as tarefas entre os filhos, evitando que alguém fique bravo com ela.

P2 - dividir igualmente as tarefas entre os filhos, porque uma boa mãe deve ser justa.

P3 - dividir igualmente as tarefas entre eles, porque todos moram juntos e têm os mesmos deveres (Fonte: pesquisa dos autores, 2015). 
Para a construção e processamento das escalas, uma para cada valor, optamos pela utilização da Teoria de Resposta ao Item (ANDRADE; TAVARES; VALLE, 2000; TAVARES, 2013). Essa teoria parte do princípio de que as variáveis investigadas pela Psicologia ou pela Educação na maioria das vezes não são observáveis diretamente como é o caso da adesão a valores. Especificamente neste estudo, o modelo da TRI utilizado foi o Modelo de Resposta Gradual de Samejima (ARAUJO; ANDRADE; BORTOLOTTI, 2009), para itens politômicos, isto é, em que várias alternativas de respostas são consideradas.

Processada a TRI foi possível identificar níveis de desenvolvimento em cada valor, referentes à adesão ou não ao valor (ser pró ou contra o valor) e às três perspectivas sociais consideradas (perspectiva egocêntrica - sociocêntrica - moral), e obter a classificação de todos os participantes da pesquisa nesses níveis. $O$ primeiro nível I corresponde ao contra-valor, o nível II ao pró-valor na perspectiva egocêntrica, o nível III pró-valor na perspectiva sociocêntrica e o nível IV corresponde ao pró-valor na perspectiva moral.

Esta pesquisa apresenta os resultados da aplicação do questionário a 1.310 professores. Eles se distribuíam em 75 escolas públicas (80\%) e privadas $(20 \%)$, a maioria do estado de São Paulo. O questionário foi impresso no formato de um pequeno caderno, composto de duas partes: uma contendo questões caracterizando o perfil dos respondentes (características gerais dos participantes e questões sobre relações sociais na escola) e outra com as questões na forma de pequenas histórias sobre os valores. Os cadernos para os professores continham 25 questões e focaram três valores por vez.

\section{Resultados}

O Gráfico 1 apresenta a distribuição dos professores pelos níveis das escalas dos quatro valores estudados - solidariedade, justiça, respeito, e convivência democrática - estimados a partir dos níveis de corte montados através do processamento da escala pela TRI. Para cada um desses níveis, foram descritas as principais atitudes que um participante do nível poderia exibir ao escolher, predominantemente, as alternativas do nível. Foram definidos quatro níveis: Nível I predomínio de respostas contra-valor, Nível II, respostas pró-valor em perspectiva egocêntrica; Nível III, respostas pró-valor em perspectiva sociocêntrica e Nível IV, respostas pró-valor predominantemente morais. 
Gráfico 1 - Distribuição dos resultados dos professores por níveis da escala dos valores.

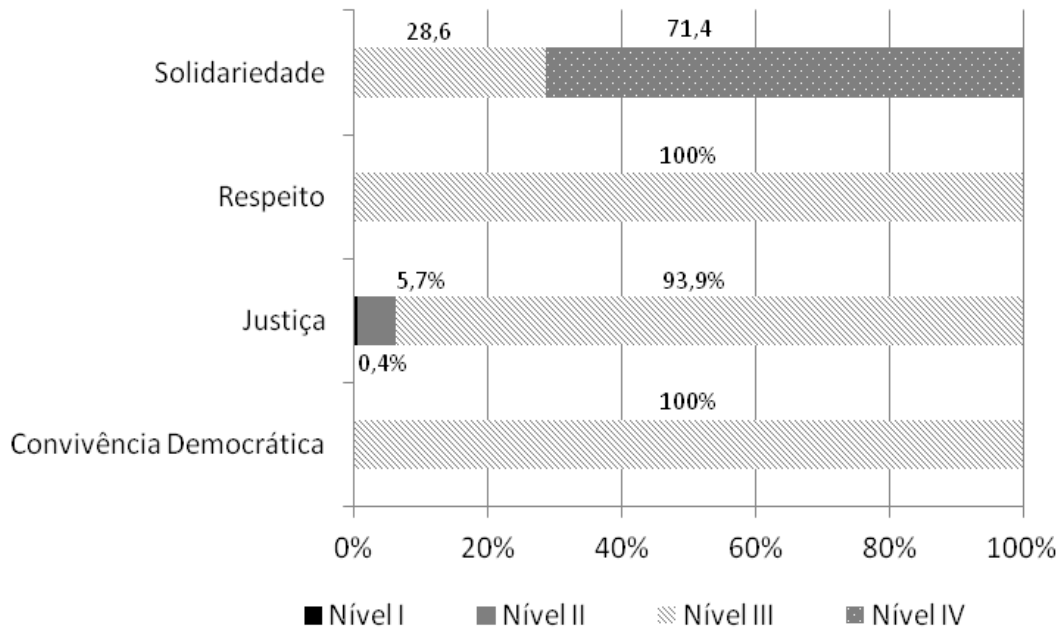

Pode-se notar que a distribuição dos participantes nos Níveis mostrou uma progressão diferente para cada valor, sendo de mais fácil adesão o valor de solidariedade (com $71,4 \%$ de participantes em Nível IV), seguindo-se os valores de respeito e de convivência democrática com a tendência total de suas respostas no nível III.

O valor de mais difícil adesão foi o de justiça já que nele não há participantes em Nível IV e, além do predomínio de participantes em Nível III, sociocêntrico, há professores em Nível II, egocêntrico, e até em Nível I, em que se destaca o contravalor.

Considerando esses resultados, podemos dizer que os professores tenderam a maior adesão aos valores numa perspectiva sociocêntrica. Isto significa que optam, frequentemente, por valores como o respeito, a justiça, ou a convivência democrática por conformidade, manutenção ou transmissão de convenções sociais ou obediência a regras e leis. Podem, também, basear-se na reciprocidade entendida como uma "regra de ouro": não faças ao outro o que não queres que te façam.

Apenas em relação ao valor de solidariedade os professores encontram-se numa perspectiva moral, propriamente dita $(71,4 \%)$. Nela, adota-se um valor por uma motivação acima das normas sociais e que reside no reconhecimento da dignidade de todo e qualquer ser humano. Nesse caso, se diz que uma pessoa tende a autonomia moral: assume valores que por si mesma reconhece como bons para si e para qualquer outra pessoa.

Dessa forma, nos parece que os professores investigados não atingiram um nível de autonomia moral em relação a três dos valores mensurados. Passemos a 
discutir e a traçar algumas considerações sobre esses resultados e o que eles nos indicam com relação à atuação desses docentes na formação moral de crianças e adolescentes.

\section{Considerações finais}

A construção de relações mais justas e respeitosas e dos valores sociomorais nelas inseridos, são, sem dúvida, metas importantes para a educação e, a escola, dependendo da qualidade das interações estabelecidas em seu interior, constitui-se num local propício para que esse desenvolvimento ocorra. É nesse ambiente que o sujeito irá conviver com o âmbito público (no sentido de coletivo), estabelecer relações de igualdade e conviver com a diversidade.

Assim, as escolas, queiram ou não, influenciam de maneira significativa na formação moral das crianças e jovens; todavia, nem sempre o fazendo na direção da autonomia. É impossível evitar mensagens que dizem respeito à moralidade, já que as normas e comportamentos presentes nas escolas fornecem informações sobre o que se considera bom ou mau, justo ou injusto. $O$ fato é que a maneira pela qual um professor organiza as regras na escola e julga, ou não, um comportamento de um aluno como inadequado pode se relacionar com a forma pela qual ele mesmo adere a um valor moral.

Como podemos constatar, quando estes professores aderem ao valor da justiça, do respeito e da convivência democrática num nível sociocêntrico (ou anterior a este, sem reconhecer o valor moral como necessário a convivência), denotam o quanto ainda esses profissionais são presos às convenções sociais. Tal conclusão pode explicar o fato de que muitos professores gastam grande parte de seu tempo em sala de aula cobrando regras como não usar boné, não usar chinelos, ou não usar canetas grifa-textos de determinada cor; mas, quando têm um conflito moral em que o respeito e a tolerância ao diferente estão em jogo, o que fazem é enviar o caso à diretoria. Sem que se deem conta, esses professores professam o quanto convenções sociais são mais importantes que princípios morais. Isso pode ser visto quando, em outro exemplo, dizem aos alunos numa briga entre os pares: "querem brigar, vão brigar lá fora" denotando o quanto um valor moral apesar de ser desejado por eles pouco é refletido durante suas aulas.

Isto pode acontecer porque há uma crença comum em nossas escolas de que a formação de personalidades éticas ocorreria por transmissão direta (pelos sermões ou lições de moral) ou seria decorrente de um desenvolvimento maturacional (e que, portanto, deveria vir de casa). Pouco se sabe, portanto, que valores como o respeito e a justiça são construídos na relação do sujeito com o meio, quando crianças e adolescentes podem tomar decisões, fazer escolhas, 
assumir responsabilidades sobre suas próprias condutas. O mesmo é válido para o diálogo e solidariedade. Certamente, a convivência democrática que tanto se deseja nas escolas é também fruto das experiências morais que ali acontecem: quando professores e alunos podem pensar sobre as regras, podem defini-las a partir de suas necessidades, podem discutir seus problemas e propor soluções viáveis, podem aprender maneiras mais assertivas para que o diálogo esteja presente entre todos. Torna-se urgente que na formação de professores o tema da convivência ética seja presente e que mais e mais possibilidades de reflexão sobre as condutas para promovê-la sejam realizadas.

O recorte aqui apresentado desta investigação sobre a adesão aos valores morais é, portanto, um alerta sobre a urgência de se pensar as questões de convivência na escola e a necessidade de que educadores sejam agentes de transformação em sua realidade, repensando suas próprias práticas e suas crenças.

\section{Referências}

ARAUJO, E; ANDRADE, D; BORTOLOTTI, S. Teoria de resposta ao Item. Revista da Escola de Enfermagem; USP; 2009; 43. (Esp); 1000-8.Disponível em:< www.ee.usp.br/reeusp>. Acesso em: 15 abr. 2015.

ANDRADE, D.F.; TAVARES, H. R.; VALLE, R. C. Teoria da Resposta ao Item: Conceitos e Aplicações. Associação Brasileira de Estatística: São Paulo. SINAPE 2000. Disponível em: <http://www.ufpa.br/heliton/arquivos/LivroTRI.pdf>. Acesso em: 10 abr. 2015.

BAUMAN, Z. O mal estar da pós-modernidade. Rio de Janeiro: Zahar, 1998.

BIAGGIO, A. M. B. Kohlberg e a comunidade justa: promovendo o senso ético e a cidadania na escola. Revista Psicologia: Reflexão e Crítica, Porto Alegre, v. 10, n. 01, p.47-69, 1997.

Lawrence Kohlberg: ética e educação moral. São Paulo: Moderna, 2002.

BRASIL, Secretaria de Educação Fundamental. Parâmetros Curriculares Nacionais. Brasília: MEC, 1997.

JARES, X. Educar para a verdade e para a esperança. Porto Alegre: Artmed Editora, 2005.

KOHLBERG, L. Psicologia del desarrollo moral. Bilbau: Biblioteca de Psicologia, Desclée de Brouwer, 1992.

KOLLER, S. H.; BIAGGIO, A. M. B.; LOPES, S.; RIQUE, J. N.; CAMINO, C.; DIAS, M. G.; COSTA, A. E. Uma investigação sobre os instrumentos de medida de 
maturidade de julgamento moral em uso no Brasil. Psicologia: Reflexão e Crítica, Porto Alegre, v. 7, n. 1, p. 5-14, 1994.

LA TAILLE, Y. Moral e Ética: dimensões intelectuais e afetivas. Porto Alegre: Artmed, 2006.

Formação Ética. Do tédio ao respeito de si. Porto Alegre: Artmed, 2009.

; MENIN, M. S. S. (org.). Crise de valores ou valores em crise? Porto Alegre: Artmed, 2009.

LIND, G. O significado e medida da competência moral revisitada: um modelo de duplo aspecto da competência moral. Psicologia: Reflexão e Crítica, Porto Alegre, v. 13, n. 3, p. 399-416, 2000.

LIPOVETSKY, G. O Crepúsculo do Dever: a ética indolor dos novos tempos democráticos. 4. ed. Lisboa, Portugal: Dom Quixote, 2010.

MENIN, M.S.S. Representações sociais de injustiça em adolescentes de escolas públicas e particulares. Psicologia da Educação, PUC-SP, n. 14/15, p.239-264, 1 e 2 semestre, 2002.

Injustiça e escola: representações de alunos e implicações pedagógicas. In: TOGNETTA, L. R. P. Virtudes e educação: o desafio da modernidade. Campinas: Mercado de Letras, 2007.

; ZECHI, J. A. M. D; SILVA, C. C. M; OLIVEIRA, A. P. Educação Moral ou em Valores nas escolas: concepções de educadores em escolas públicas brasileiras. In: ENCONTRO DE PESQUISA EM EDUCAÇÃO DA REGIÃO SUL, 8., 2010, Londrina. Anais... Londrina: ANPED, 2010. p.1-12.

; BATAGILA, P.U.; ZECHI; J. M. Projetos bem sucedidos de educação em valores. São Paulo: Cortez Editora; 2013.

; BATAGLIA, P. U. R.; MORO, A. Adesão ao valor de justiça entre crianças e adolescentes. Estudos em Avaliação Educacional, v. 24, n. 56, set/dez 2013, p. 18-47.

PIAGET, J. O Julgamento moral na criança. São Paulo: Mestre Jou, 1977.

REST, J. DIT Manual: manual for the Defining Issues Test. Minneapolis: University of Minnesota, 1986.

SELMAN, R. L. The growth of interpesonal understanding: developmental understanding. Nova lorque, EUA: Séries Editor, 1980. 
; BEARDSLEE, W.; SCHULTZ, L; KRUPA, M.; PODOREFSKY, D. Assessing adolescent interpersonal negotiation strategies: Toward the integration of structural and functional models. Developmental Psychology, v. 22, n. 4, p. 450-459, 1986.

SHIMIZU, A. M. Defining Issues Test: fidedignidade da versão brasileira e ponderações acerca de seu uso em pesquisas sobre moralidade. Psicologia: Reflexão e Crítica, Porto Alegre, v. 17, n. 1, p. 5-14, 2004.

; URANO, M. M. Defining Issues Testes 1 y 2: cálculo de confiabilidad de las versiones castellanas y consideraciones acerca de su uso en estudios sobre moralidad . Investigaciones En Psicología Revista Del Instituto de Investigaciones, Buenos Aires, Argentina, v. 9, n. 2, p. 41-57, 2004.

SPOSITO, M. P. Um breve balanço da pesquisa sobre violência escolar no Brasil. Educação e Pesquisa, São Paulo, v.27, n. 1, p. 87-103, jan/jun. 2001.

TAVARES, M. R. Avaliação de valores sociomorais: procedimentos para a construção de uma escala. Estudos de Avaliação Educacional. São Paulo, v. 24, n. 56, set/dez.2013 p.252-272.

TOGNETTA, L. R. P.; VINHA, T. P. Quando a escola é democrática: um olhar sobre a prática das regras e assembléias na escola. Campinas: Mercado de Letras, 2007.

Perspectiva ética e generosidade. Campinas: Mercado de Letras, 2009.

et al. Um panorama geral da violência na escola e o que se faz para combatê-la. Campinas: Mercado de Letras, 2010.

TREVISOL, M. T. C. Tecendo os sentidos atribuídos por professores do ensino fundamental ao médio profissionalizante sobre a construção de valores na escola. In: LA TAILLE, Y; MENIN, M.S.M. (Org.). Crise de valores ou valores em crise? Porto Alegre: Artmed, 2009. p. 152-184.

VAZQUEZ, A.S. Ética. Rio de Janeiro: Editora civilização brasileira S. A., 1993.

VINHA, T. P. O Educador e a moralidade infantil numa visão construtivista. Campinas: Mercado de Letras, 2000.

Os conflitos interpessoais na relação educativa. 2003, 426 f. Tese (Doutorado em educação). Faculdade de Educação, Universidade Estadual de Campinas, UNICAMP, Campinas, 2003.

ZECHI, J. A. M. Violência e Indisciplina em meio escolar: aspectos teóricometodológicos da produção acadêmica no período de 2000 a 2005. 2008. 152 f. Dissertação (Mestrado em Educação) - Faculdade de Ciências e Tecnologia, Universidade Estadual Paulista "Júlio de Mesquita Filho", Presidente Prudente, 2008. 


\title{
Literatura infantojuvenil, visualidades e links: interações e leituras
}

\author{
Rodrigo da Costa Araujo
}

Fabiano Tadeu Grazioli

Rosemar Eurico Coenga

\section{Ilustração \& hipertextualidade}

\begin{abstract}
Para avançar na leitura é preciso um gesto que atravesse a solidez material do livro e dê a você o acesso à substância incorpórea dele. Penetrando por baixo entre as folhas, a lâmina sobe impetuosa e abre um corte vertical numa fluente sucessão de talhos que investem contra as fibras uma a uma e as ceifam. [...] A borda das folhas se rompe, revelando o tecido filamentoso; um fiapo sutil - dito "encaracolado"- se destaca, suave como a espuma de uma onda. Abrir uma passagem com o fio da espada na fronteira das páginas sugere segredos encerrados nas palavras: você avança na leitura como quem penetra uma densa floresta. (CALVINO, 1999, p. 48).
\end{abstract}

A imagem, essencialmente a ilustração de livros infantojuvenis, tem ocupado lugar de destaque na sociedade moderna, não só na produção gráfica e editorial, mas em outros vários seguimentos, a exemplo do que ocorre no setor publicitário e no espaço virtual. Em virtude disso e pautando-se nessa dinâmica, é notório que as publicações literárias para crianças e jovens ${ }^{4}$ tenham primado por ilustrações de qualidade, visando, assim, a garantir a preferência do público consumidor, ampliando, por sua vez, o mercado para designers, ilustradores e outros profissionais do mercado editorial.

Essa literatura, apoiada em vários recursos da linguagem visual e no contexto da hipermídia, apresenta-se e se propõe como lugar criativo de manifestação da experiência das imagens ou como ponto de friç̧ão e de interpretação de linguagens. Ao considerar esses olhares, o jogo dos intertextos e de links em algumas tramas e

\footnotetext{
${ }^{4}$ Ler melhor a esse respeito em: SERRA, Elizabeth Org. A arte de ilustrar livros para crianças e jovens no Brasil. Fundação Nacional do Livro infantil e juvenil. Rio de Janeiro: FNLIJ, 2013.
} 
obras, essa comunicação oral pretende analisar o livro infantojuvenil e a ilustração como corpus e leitura estética e visual.

Sem desconsiderar esses detalhes, o universo do texto literário para criança e jovens, principalmente a partir da década de 90 , recebeu uma migração de artistas plásticos que concebe o objeto livro de outra maneira; ele se apresenta no jogo e concentração de linguagem de natureza vária e variada, e, por isso mesmo, perde, definitivamente, o estatuto de mero instrumento decorativo ou puramente literal. Os avanços tecnológicos e a articulação com os vários ambientes midiáticos integramse, imitam ou aproximam-se da sua confecção, fortalecendo o intercâmbio de culturas, saberes e textos e reconhecendo, assim, o perfil do leitor do terceiro milênio. Nesse contexto, a hibridização de códigos, linguagens e mídias suscita novo leitor e outra interatividade com o design digital. Dessas confluências de mídias e hibridização das esferas tecnológicas, emerge o dinâmico universo hipermidiático.

Os livros contemporâneos e suas ilustrações solicitam, de algum modo, novos paradigmas de pensar, agir e sentir ou ensinar esse novo modo de leitura. As características de sua estrutura multilinear e multissequencial requerem um leitor/receptor capaz de interagir, por meio de escolhas e percepção astuta, suas descobertas, enredos, objetivos.

Ao acompanhar esse contexto multifacetado, fluido e não-sequencial, "Abrindo Caminho", de Machado (2004), "Cantiga” de Blexbolex - pseudônimo de Granger (2014), "Abra este pequeno livro”, de Klausmeier (2013) e "Alice Viaja nas Histórias", de Rodari (2007), exploram as formas tradicionais de som, imagem e escrita que se metamorfoseiam, representando uma espécie de cartografia por meio de elementos-chave ou links (nexos associativos).

Com o intuito de sugerir essa cartografia de certos sistemas visuais com a aparente falta de arranjo sistemático - em que a coerência e a coesão dentro de uma dialética da desordem são mantidas - recorre-se às contribuições teóricas do hipertexto ${ }^{5}$. Essas contribuições oferecem novas possibilidades de leitura ao incorporar em sua dinâmica o modo fragmentado e fluido com que a memória opera, pois ele "[...] não é feito para ser lido do começo ao fim, mas sim através de buscas, descobertas e escolhas". (SANTAELLA, 2007, p. 308). Assim, "[...] permite ao leitor abrir janelas e mais janelas no texto, promovendo um encadeamento com outros textos e contextos, sem seguir necessariamente as trilhas já traçadas". (WALTY, 2006, p. 117).

Acompanhando o formato hipertextual, essas obras estão sujeitas a volatilizarem-se, seguindo o curso de um rizoma, o qual imbrica em uma cadeia de caminhos formada por vários blocos interdependentes que permite redescobrir a

\footnotetext{
${ }^{5}$ Hipertexto é um conjunto de nós ligados por conexões. Os nós podem ser palavras, imagens, gráficos ou parte de gráficos, sequências sonoras, documentos complexos que podem eles mesmos ser hipertextos. [...] Navegar em um hipertexto significa portanto desenhar um percurso em uma rede que pode ser tão complicada quanto possível. Porque cada nó pode, por sua vez, conter uma rede inteira. (LÉVY, 1993, p. 33).
} 
autonomia e a importância das partes. Logo, tal multiplicidade dota o texto/livro de um excesso de entradas e saídas que podem transbordar por uma linha de fuga e ultrapassar o próprio livro.

O objetivo dessa leitura não é apresentar questões pertinentes à natureza e às tipologias da imagem, nem discutir o que está subjacente aos mecanismos editoriais no que concerne à circulação do livro infantojuvenil, mas mostrar algumas modalidades literárias em que a imagem visual se faz decisiva no processo de motivação de transposição para o nível do abstrato e convencional do código escrito ou virtual, fortalecendo, por outro lado, uma expressividade peculiar e representativa da literatura infantojuvenil com a tecnologia e com a versatilidade estética da leitura pela ilustração.

A partir dessas premissas, torna-se fundamental destacar que, nesse fluxo de linguagens, o livro impresso também é afetado significativamente pela cibercultura, constituindo-se, assim, em um campo fértil de experimentações literárias, especialmente para crianças e jovens. Ou seja, nessas obras:

Diversos códigos migram para livro, da mesma forma como códigos do livro migram para outros suportes, e, com esse trânsito, os textos vão assumindo características de estrutura hipertextual; o que vai requerer um programa de acesso via leitura com características de um mapa de navegação multidirecional e interativo do hipertexto do computador para explorar os limites e possibilidades desse hiperlivro, feito de links múltiplos, que vão traçando vias permutacionais pelas quais é possível navegar. (CUNHA, 2008, p.49).

\section{Leitura, visualidades \& versatilidade}

‘Leitura de imagens”, de Santaella (2012), é, como o próprio título encaminha, uma obra que se propõe a pensar o ensino teórico e prático da leitura de elementos não-verbais e suas possíveis significações, além de elementos estéticos em signos visuais. Para tal proposta, a pesquisa dedica-se às imagens fixas e bidimensionais, ou seja, centra-se nas imagens que podem ser representadas em superfícies planas ou impressas.

A introdução do livro - porta de entrada para a proposta - trata da necessidade de expandir o conceito de leitura, uma vez que ele não fica restrito ao código linguístico ou a elementos predominantemente verbais. Mais do que nunca, a escrita, unida à imagem, ao som, ao movimento, ou a outros recursos imagéticos, afasta a "[...] visão purista da leitura restrita à decifração da letra [...]" (SANTAELLA, 2012, p. 11) do enunciado verbal, construindo, a esse modo, um novo leitor, chamado pela autora de "leitor imersivo".

Santaella (2004) compreende o leitor imersivo como aquele que navega sobre a liquidez dos signos, construindo mapas de leitura a partir da escolha de rotas e 
direções em um roteiro multilinear e labiríntico, juntando fragmentos, os quais se vinculam por meio de uma lógica associativa. Esse leitor, segundo suas premissas, assemelha-se a uma espécie de flâneur .

Para fundamentar o conceito de leitura que a obra amplia, Santaella (2012), considera e retoma intertextualmente a expressão visual literacy (letramento visual ou alfabetização visual). Partindo dessa premissa, para se ler uma imagem,

[...] deveríamos ser capazes de desmembrá-la parte por parte, como se fosse algo escrito, de lê-la em voz alta, de decodificá-la, como se decifra um código, e de traduzi-la, do mesmo modo que traduzimos textos de uma língua para outra [...] (SANTAELLA, 2012, p. 12).

Ressignificada, a alfabetização visual, nesse caso, significa aprender a ler imagens, desenvolver a observação de seus aspectos e traços constitutivos, detectar o que se produz no interior da própria imagem, sem, no entanto, fugir para outros pensamentos que nada têm a ver com ela. Ou seja, nessa perspectiva, significa adquirir os conhecimentos correspondentes e desenvolver a sensibilidade necessária para saber como as imagens se apresentam em suas diversas facetas e modos específicos.

Na rubrica "O que é imagem", Santaella (2012) discute o conceito de imagem retomando princípio platônico: existem imagens naturais - como as refletidas na água - e existem imagens artificiais - como as produzidas, criadas ou recriadas pelo homem. Com base nessa distinção, a estudiosa instaura uma breve discussão entre os ideais naturalistas e os convencionalistas sobre a imagem. Porém, os dois vieses possuem o caráter de duplo, inerente e decorrente da similaridade entre imagem e o que dela pode ser representado.

O terceiro e o quarto capítulo da obra exploram as imagens que articulam e integram, em sua composição, a palavra e a imagem e as suas relações diversas na construção de sentidos. Na rubrica "Imagens nos livros ilustrados", são estudadas as proximidades entre imagem e texto, considerando três tipologias como forma de leitura dos enunciados verbo-visuais: as relações sintáticas, semânticas e pragmáticas.

O quinto e último capítulo trata das rubricas "Imagens no design" e "A imagem no contexto da hipermídia”. Este último olhar, em consonância com a discussão proposta, conceitua e apresenta a hipermídia como a nova configuração de linguagens humanas, constituída pela fusão do hipertexto com a multimídia. $\mathrm{O}$ hipertexto caracteriza-se, segundo Santaella (2012, p. 177),

[...] por nós ou pontos de intersecção que, ao serem clicados, remetem a conexões não lineares, compondo um percurso de leitura que salta de um

\footnotetext{
${ }^{6}$ O flâneur é um observador que se estimula em fixar residência na multiplicidade, onde tudo se move, infinito e evanescente. É um personagem errante e misterioso que teve origem na obra de Baudelaire. O flâneur é consciente, livre, preserva a própria identidade e emerge em tempos diversos, ele é capaz de retornar e remontar o passado histórico a partir do presente, apontando para um futuro cheio de possibilidades.
} 
ponto a outro de mensagens contidas em documentos distintos, mas interconectados [...].

$\mathrm{Na}$ conexão dos hipertextos com documentos distintos e multimidiáticos (fotos, músicas, vídeos etc), inaugura-se uma nova maneira de formar, configurar e disseminar informações: a hipermídia.

"Leitura de imagens", em seu conjunto, questiona ou desconstrói opiniões, ideias e concepções que, muitas vezes, são instituídas como naturais, necessárias, consensuais, para a leitura ou trabalho pedagógico com a imagem. Nesse sentido, a obra traz importantes reflexões e críticas sobre ideias estabelecidas pelo senso comum.

Discutir as condições atuais de produção de leitura, numa interseção entre o livro literário e as diversas mídias, torna-se fundamental para quem busca uma aproximação dos sentidos da leitura, ou da versatilidade que ela propõe ou instaura. Hoje, mais do que nunca, no cenário dos estudos sobre a leitura, cresce a preocupação com a multimodalidade, ou seja, com os espaços multimodais, em que os sentidos são construídos a partir de recursos como gestos, olhares, postura e disposição de objetos visuais: esse conceito vem produzindo desdobramentos no campo dos estudos sobre a literatura para crianças e jovens.

\title{
Livros, ilustrações \& links
}

\begin{abstract}
Texto, imagem e som já não são o que costumavam ser. Deslizam uns para os outros, sobrepõem-se, complementam-se, confraternizam-se, unem-se, separam-se e entrecruzam-se. Tornam-se leves, perambulantes. Perderam a estabilidade que a força de gravidade dos suportes fixos lhes emprestavam. Viraram aparições, presenças fugidias que emergem e desaparecem ao toque delicado da pontinha do dedo em minúsculas teclas (SANTAELLA, 2007, p. 27).
\end{abstract}

Em tempos de proliferação das linguagens - inclusive nas ilustrações contemporâneas - e de toda espécie de misturas que correspondem a fusões, combinações e simultaneidades das redes culturais, tratar da leitura literária, e consequentemente do livro como objeto artístico, requer uma compreensão mais aberta do que até então se considera literatura, para evitar o risco de não alcançar a complexidade desse tema. Para discutir o que destacamos como versatilidade do leitor, nesse texto, trazemos exemplos de algumas reflexões por meio das obrasrecorte.

Em "Abrindo Caminho", de autoria de Machado (2004), e ilustrado por Teixeira, acompanham-se construções circulares, formas fragmentadas, rizomáticas e labirínticas, que instigam visualmente o jogo de retomadas, e interatividade com o 
leitor, segundo a teoria de Santaella (2007). A figura a seguir representa a capa do livro.

Figura 1 - Capa do livro "Abrindo Caminhos"

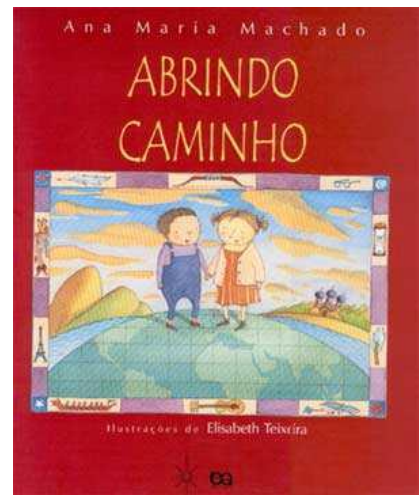

Fonte: Machado (2004).

Nessa fabricação texto-visual, nota-se que a arquitetura narrativa gira em torno de três grupos, os quais se referem cada um a três personagens. O primeiro trata dos sujeitos ligados à poesia, aludindo a Dante Alighieri, Carlos Drummond de Andrade e Tom Jobim. O segundo seria das grandes personalidades da História, mencionando Cristóvão Colombo, Marco Pólo e Alberto Santos Dumont. Já o terceiro reporta-se a uma garota, um menino e ao leitor da obra, os quais se relacionam, respectivamente, com as divisões anteriores, feito retomadas em mise en abyme.

Assim, mesmo que aparentemente, os fragmentos e as micronarrativas se re(inter)cruzam, engendrando-se em um espaço de simultaneidade e sobreposição de acontecimentos que se multiplicam em um diagrama de vozes e combinações, nos quais o leitor é obrigado a ziguezaguear por uma estrutura não mais linear e fixa. Contudo, o que se estabelece é uma conexão multiespaço-temporal que, a partir de links, constrói os sentidos em uma vasta rede hipertextual sempre em crescimento, assemelhando-se a uma enciclopédia ou espécie de biblioteca virtual.

Já a dialética entre o visual e o imaginário, entre os manejos da materialidade e o sopro do imaterial, são algumas das principais linhas de força da viagem ou da cantiga poética do artista plástico francês Blexbolex, publicada recentemente pela editora Cosac Naify. "Cantiga" (2014), de Blexbolex - pseudônimo de Bernard Granger - já conquistou o público e o mercado da literatura infantojuvenil na Europa e nos Estados Unidos, porque foi eleito, pelo New York Times Boocks Reviews, como um dos dez melhores livros ilustrados de 2013. A obra também recebeu prêmio Pépite du Livre Orni, na França. Reproduzimos a capa do livro na Figura 2. 
Figura 2 - Capa do livro "Cantiga"

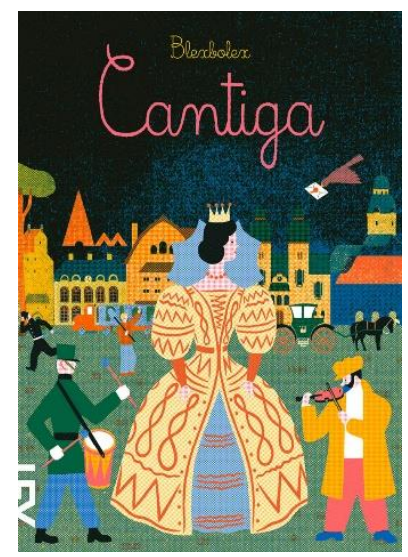

Fonte: Blexbolex (2014).

Dividido em sete capítulos, o livro funciona como museu de imagens delicadas, trazendo as marcas da musicalidade poeticamente administradas. São figuras que, a cada recomeço - como gestos da oralidade ou mesmo links visuais -, vão ganhando novos personagens, cores e sentidos. Em outros momentos e conexões, as paisagens e esses personagens ou cenas cotidianas retomam lendas alemãs, mas também podem ser encontradas em histórias populares que circulam pelo mundo todo.

Blexbolex escreve e ilustra esses elementos com criatividade e fino acabamento, coincidindo com os traços minimalistas de recortes desenhados com refinado encanto. Dinamiza o livro e o enredo de "Cantigas", em fragmentos, com base numa escala rítmica em que se revezam palavras e pequenas frases, com refrãos que se repetem e servem como legendas para os desenhos.

Por fim, "Cantiga", de Blexbolex (2014), constitui-se num livro em que a reflexão sobre as cantigas e a oralidade justapõe o presente e o passado, interroga realidades aparentemente óbvias, para representar nas suas instigantes imagens 0 fluxo e o refluxo da condição humana e das imagens do mundo em links. Tal reflexão é realizada em conjunto com suas ilustrações e traços da obra: o ato de fixar e olhar mais alto, na exata medida em que sua arte, à feição de humanista e dos artistas plásticos, pesa e mede as palavras. Definitivamente, "Cantiga" funciona como um elogio não somente aos olhos, ao ato de ouvir e de contar histórias, mas também ao mundo da arte. 
Figura 3 - Capa de "Abra este pequeno livro"

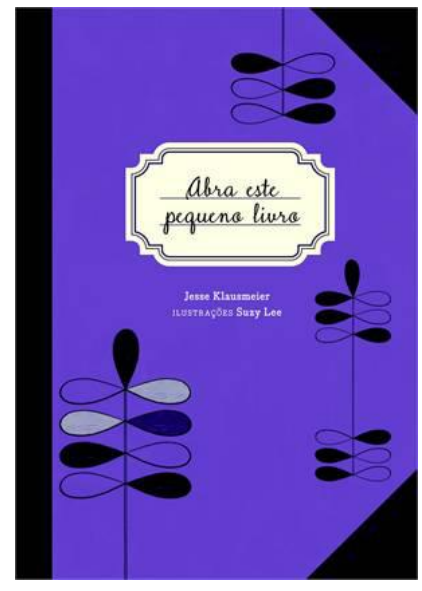

Fonte: Klausmeier (2013).

"Abra este pequeno livro"7, de Klausmeier (2013) e com ilustrações de Lee, cuja capa é ilustrada pela Figura 3, revela, num primeiro lance de olhar, o jogo metalinguístico do processo da leitura ou do próprio ato de brincar com o livro. Jogo relacional, além de apelativo pelo título que nomeia a obra, a brincadeira propõe equações, referências recíprocas de um sistema de signos e de linguagem.

Figura 4 - Detalhe de "Abra este pequeno livro"

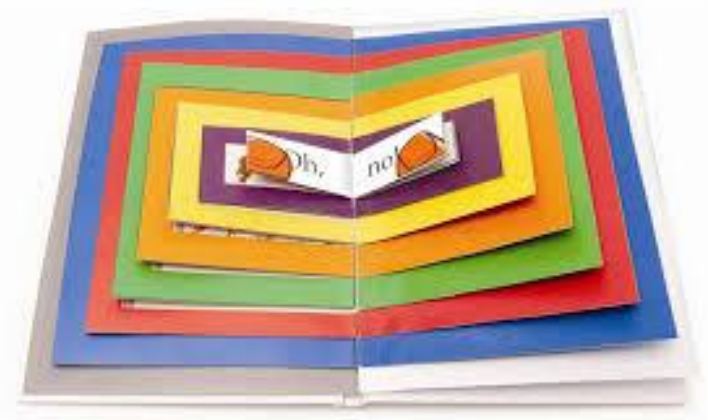

Fonte: Klausmeier (2013).

Espécie de elogio ao livro e à leitura, "Abra este pequeno livro"- que não tem nada de pequeno - é, também, metáfora e estratégia da leitura como jogo da memória ou identidade individual e coletiva, bem como baú que guarda alguma visão de mundo, impressões visuais e hipertextuais, relações, descobertas, saberes, memória poética ou links visuais.

${ }^{7}$ Livro que recebeu o prêmio da FNLIJ Monteiro Lobato como melhor tradução/adaptação para criança em 2014. 
A obra sugere que um personagem abra um novo livro - já que há vários dentro dela - e o leitor, por sua vez, o acompanhe nessa experiência, até o infinito de livros e leituras, descobertas e horizontes. O livro, como um todo, é a arte e arte de inventar, de fingir, de enganar e ao mesmo tempo mostrar o seu engano. Essas atitudes são vistas em livros que se repetem na ilustração e na própria estrutura da obra, na leitura que se propõe e no ato de folhear, nas bordas das páginas que escondem e prolongam, visualmente, um quantitativo de páginas que não existem de fato, no gesto de abrir e fechar, na multiplicidade poética de livros e leituras nas mãos dos personagens e na mão do próprio leitor. É, também, uma linguagem instauradora de realidades e exploradora de sentidos, a qual possui uma capacidade de gerar, tanto na forma impressa, como poética, inúmeras significações a cada nova leitura ou olhar, porque a leitura é, a partir daí, uma estratégia visual/hipertextual.

Semelhantes aos hipertextos, ou acompanhando essas características, os livros que se abrem dentro de um livro maior, com capa dura e em tons de roxo e lilás, trazem formatos inovadores, proporcionando uma experiência de leitura estética, criativa, lúdica e interativa. Dentro de cada livro, escondem-se livros menores, até ficarem menores ainda, tão menores do que o dedo da giganta da história, que precisará da delicadeza do ato de virar a página. Lee e Klausmeier (2013) criam, ludicamente, livros dentro de livros que merecem ser lidos em suas individualidades, delicadezas e gestos específicos. Leitura e sentidos, os sentidos da leitura, ou mesmo, a leitura pelos sentidos: o ver, o ler, o sentir, o manusear.

Figura 5 - Capa do livro "Alice viaja nas histórias"

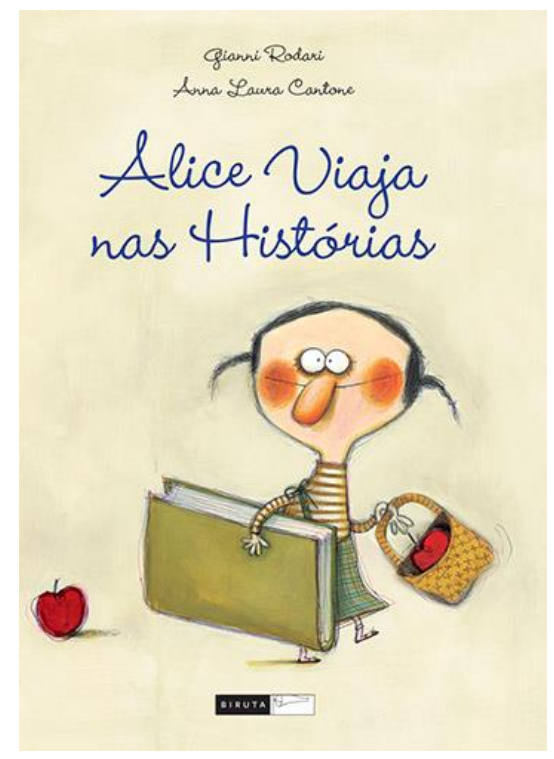

Fonte: Rodari (2007). 
Como quem acompanha o gesto dos links, quem folheia "Alice viaja nas histórias", do italiano Gianni Rodari e com ilustrações de Anna Laura Cantone (2007), não tem como não ficar encantado com as viagens, a memória de leitura e o deleite visual. Qualquer leitor atento experimentará os links como estratégias de retomadas e memória, tanto visual como hipertextual.

"Alice viaja nas histórias" cresce, alonga-se, como os tempos e links dos contos de fadas pelos séculos afora, em profusão: palavras, pensamentos, vontades, acúmulo, leituras infinitas, páginas e paisagens. Uma biblioteca de Alice? E o livro multiplica-se, porque ele se alastra, e ri: enquanto houver histórias e livros, o leitor estará tomado, possuído dos pequenos recuos, dos adjetivos cheios, dos vocábulos encharcados, cobrindo, com folhas e leituras, as páginas. O desenho do rosto de Alice permanecerá, tal como comprovam os retratos, praticamente o mesmo. Por isso, ela não morre e atravessa séculos e linguagens.

O livro inteiro é um elogio à leitura, à literatura ou a certa hipertextualidade que faz do enredo uma rede de citações. É uma memória, trabalho de retomadas que não apenas narram: recolhem, imprimem, espalham, retém, recriam. Costuras, lembranças, sensações. Histórias que correm de dentro para fora, para cima e para baixo, para lá e para cá. Agita mil fragmentos díspares, ora iluminados, ora em sombra, pendentes, oscilantes, errantes.

O texto literário e suas formas na contemporaneidade, bem como sua relação com o imagético ou o visual se relacionam diretamente com as possibilidades de exploração da leitura e das linguagens na Educação Infantil. As obras "Abrindo Caminho", de Machado (2004), "Cantiga" de Blexbolex - pseudônimo de Granger (2014), "Abra este pequeno livro", de Klausmeier (2013) e "Alice Viaja nas Histórias", de Rodari (2007), propiciam ricas descobertas para as crianças em sua fase de socialização.

Nessa perspectiva, o trabalho com a literatura na Educação Infantil, implica pensar a criança como produtora de cultura, assumindo dessa maneira um papel fundamental não apenas na formação de leitores, mas também na própria constituição da subjetividade da criança.

Em sua obra Da escuta de textos à leitura (2007), Elie Bajard destaca que:

A ficção tem um papel central na construção da personalidade infantil. Papel com o qual outros gêneros não podem concorrer. De fato, a criança precisa, desde muito cedo, construir para si um universo imaginário, chave da interpretação do mundo real. [...] A literatura infantil deve ocupar um espaço significativo junto às crianças, na escola e fora dela, e por isso cabe iniciar a convivência com o livro desde os primeiros meses de vida. (BAJARD, 2007, p, 41-43).

Acreditamos que investir em uma metodologia que privilegie o trabalho com esses textos pode despertar nas crianças a imaginação, a criatividade, o senso crítico e criativo. A leitura da literatura deve ser uma das principais ferramentas do 
professor, mediador de leitura por excelência e deve estar presente na vida escolar desde a Educação Infantil, desfazendo a ideia equivocada que ainda permanece em muitos espaços, principalmente no familiar, de que as crianças não devem e não podem manusear livros, acessar textos, ouvir histórias, compartilhar a poesia, participar de eventos letrados diversos antes de aprenderem a falar e a escrever. $\mathrm{O}$ mundo da ficção propicia a criança a elaborar seus medos, frustações, ansiedades, e ainda, possibilita a vivência de aventuras, amplia o rol de histórias conhecidas podendo estabelecer relações com outros textos, os já conhecidos, e também aprende sobre a estrutura deste gênero e sobre a sua linguagem.

No entanto, outros requisitos são necessários a serem desenvolvidos em salas de Educação Infantil, dentre eles, a formação do (a) educador (a) da infância, como mediador de leitura, reveste-se de fundamental relevância. Além de ser leitor (a), cabe a ele (a) comprometer-se com a formação leitora das crianças, manter-se atualizado sobre a produção literária destinada a este público, propiciar momentos significativos de fruição literária e conhecer as preferências e interesses de seus alunos para que selecionar livros cada vez mais adequados ao mundo circunscrito pela Educação Infantil.

Por fim, cremos também que o (a) educador (a) necessita ser um bom contador de histórias, a fim de poder compartilhar sua paixão pela leitura; para poder dialogar com as crianças sobre os livros, os autores, os ilustradores; para assim, estabelecer pontes-relações com o texto a partir de seus textos-vida e textos lidos.

\section{Considerações finais}

Por meio de visualidades, exercício interativo de leitura e jogo, foi possível imergir nas malhas ou redes textuais que compõem os livros "Abrindo Caminho", "Cantiga", "Abra este pequeno livro" e "Alice viaja nas histórias", revisitando-os, olhando-os (sem pressa alguma), percebendo outros textos, livros ou imagens de livros que eles guardam ou aludem. Essa navegação visual e impressa pelas páginas e nexos reforçam e estabelecem, de alguma forma, certa trama de linguagens guiada pelas percepções dos leitores, possibilitando compreender que cada itinerário é uma descoberta nova (de caminhos que se bifurcam, como quis Borges) e que nunca se está perdido na profusão de fios (ou rede que eles retomam, reforçam, reconstituem, refazem, reescrevem, recontextualizam visualmente).

Essa atividade leitora e essa versatilidade, de pausar, provisoriamente, em uma página, à espera de novas descobertas ou detalhes, possibilitaram a amplidão de um olhar para além dos horizontes nacionais, em um encontro com o outro, com muitos, com traços e descobertas. Do veio teórico utilizado para perceber essa intricada rede de fios múltiplos da ilustração, emergem novas leituras e visualidades, 
além de um novo perfil do leitor cognitivo, como via de acesso e maneiras de entender as interfaces criadas, bem como proporcionar a percepção dos complexos enlaces da cultura e da língua.

Os livros utilizados como recortes para esta leitura - em suas diversas configurações e linguagens - são, nesse sentido, exemplos de sugestões visuais ou impressas de hipertextos, pois se constituem de centros e hierarquias provisórios que se estabelecem na interação do leitor com o tecido texto-visual por meio de uma produção em rede multilinear: é certo mapa de linhas que remete ao mundo, à cultura e à leitura. Eles, em sua potencialidade ou versatilidade de leitura, abarcam, pelo jogo interativo e visual, o que Santaella (2012) reforça como novas configurações da imagem em um novo ambiente altamente híbrido, o da hipermídia.

Clicadas, a palavra ou a imagem podem nos levar a outros cantos e esquinas da rede e nelas encontraremos outros textos explicativos ou imagens ilustrativas. É difícil prever o que vamos encontrar. De todo modo, os livros em questão sugerem uma leitura em rede, inteiramente feita de conexões, e chegar a elas depende do usuário, de suas visualidades, leituras e interações. Por meio de suas ações interativas, fragmentos de ilustrações, partes de algum desenho vão se juntando a outras partes de outra ilustração, transmutando-se em intocáveis versões que brotam, na medida em que o receptor/leitor se coloca em posição de coautor desse processo. Isso só é possível devido à estrutura de caráter "hiper", não-sequencial, multidimensional, que dá suporte às opções daquele que Lucia Santaella (2012) consagrou como "leitor imersivo".

Esse leitor, por sua vez - e a partir dessas reflexões estéticas e pedagógicas -, deve perceber os processos dinâmicos de produção e recepção (hiper) textual, os quais pressupõem a desconstrução de lugares fixos, uma vez que eles e torna, também, coautor dos sentidos, da interação do movimento a linear, contínuo, multidirecional das tramas e artimanhas que a obra sugere. Em mais de um livro do recorte estudado, as ilustrações são integradas à linguagem verbal, a qual, por sua vez, estaria integrada aos enunciados não-verbais (ou visuais) em um procedimento que resultaria em uma duplicação da leitura.

A literatura infantojuvenil contemporânea, seja ela da criação impressa - com os recursos extremamente visuais e apelativos ou técnicas de designers - ou das tramas virtuais e labirínticas com seus recursos hipermidiáticos, assume, definitivamente, novas formas de ler/ver e inéditas maneiras de conceber o objeto livro. A abordagem impresso-virtual trouxe uma nova perspectiva da tecnologia enquanto fonte cultural. As diversas linguagens utilizadas, sons, movimentos, imagens e, sobretudo, a interatividade, transformaram a leitura e releitura do conto numa experiência criativa e pedagógica.

Assim, estudar literatura ou estabelecer novas práticas com o processo de alfabetização visual e leitura é correlacionar, o tempo todo, diferentes sistemas de signos. Desse modo, sempre num ambiente descontraído e lúdico, percebemos, por 
um lado, como a linguagem das ilustrações e do mundo artístico sofre os efeitos e características de diferentes códigos, e, por outro lado, como esses efeitos agem sobre eles, o que, de certa forma, provoca um processo ininterrupto de transformação com o trabalho da linguagem, um trabalho que ganha força com os vários recursos tecnológicos.

Enfim, o trabalho lúdico com a leitura e a literatura infantojuvenil de boa qualidade é o lugar, comprovadamente, de manifestações da linguagem, e que faz confluir, além dos diversos códigos e manifestações culturais, um ambiente diverso e atraente. Além do mais, pela literatura infantojuvenil, a sensibilização artística da leitura das ilustrações acontece em comum com as mutações do mundo das linguagens, linguagens pelas quais o concreto histórico fala e se relaciona semioticamente.

\section{Referências}

BLEXBOLEX. Cantiga. Tradução Alexandre B. de Souza e Érka N. Vieira. São Paulo: Cosac Naify, 2014.

BAJARD, Elie. Da escuta de textos à leitura. São Paulo: Cortez, 2007.

CALVINO, I. Se um viajante numa noite de inverno. São Paulo: Companhia das Letras, 1999.

CUNHA, Maria Zilda. Entre livros e telas - a narrativa para crianças e jovens: saberes sensíveis e olhares críticos. In. VI Atlântica, n.14. São Paulo: Universidade de São Paulo, 2008.

KLAUSMEIER, Jesse. Abra este pequeno livro. llustrações de Suzy Lee. São Paulo: Cosac Naify, 2013.

LÉVY, Pierre. O que é o virtual? São Paulo: Editora 34, 1996.

MACHADO, Ana Maria. Abrindo Caminho. Ilustrações de Elisabeth Teixeira. São Paulo: Ática, 2004.

RODARI, Gianne. Alice Viaja nas Histórias. Ilustração Anna L. Cantone. Tradução Silvana C. Leite e Denise M. Marino. São Paulo: Biruta, 2007.

SANTAELLA, Lúcia. Cultura das mídias. São Paulo: Experimento,2004.

. Linguagens líquidas na era da mobilidade. São Paulo: Paulus, 2007.

. Leitura de imagens. São Paulo: Melhoramentos, 2012. 
SERRA, Elizabeth (Org.). A arte de ilustrar livros para crianças e jovens no Brasil. Fundação Nacional do Livro infantil e juvenil. Rio de Janeiro: FNLIJ, 2013.

WALTY, Ivete Lara Camargo. Palavra e imagem: leituras cruzadas. BeloHorizonte: Autêntica, 2006. 
PARTE II. As crianças e seu cotidiano: narrações sobre os fazeres pedagógicos na educação infantil

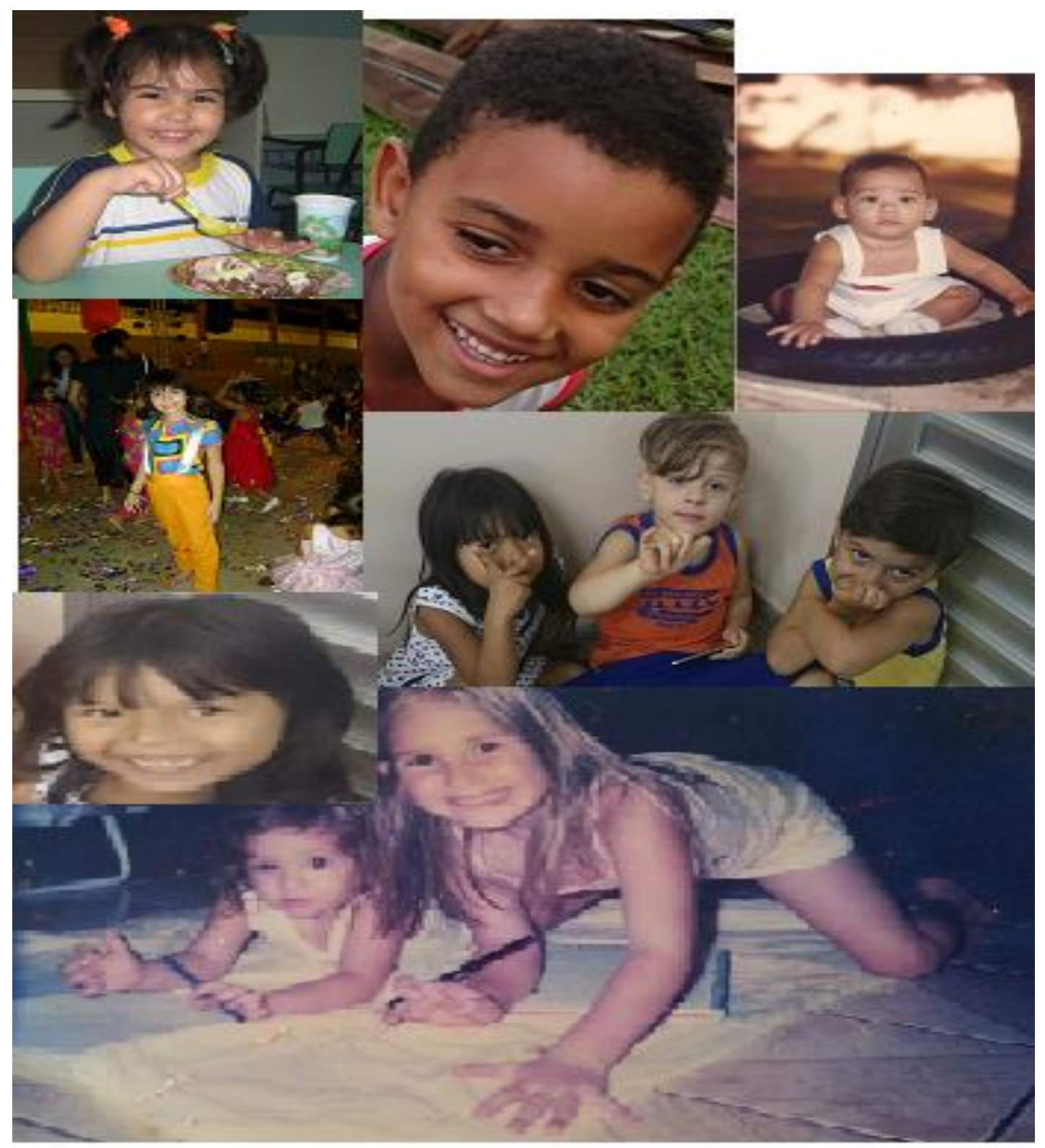

Fotos: Juracy Pacífico; Josélia Neves. 


\title{
A influência do brincar abordado de maneira livre na educação infantil
}

\author{
Kathiusa O'Hara Felipe
}

Peterson da Paz

\section{Introdução}

O brincar é coisa séria, nele está a essência da infância; contudo ainda são poucos educadores que veem esta prática como primordial para o desenvolvimento da criança. Durante o momento de brincar muitas coisas acontecem e é neste momento que a criança demonstra sua visão de mundo, suas angústias e seus encantos, pontos primordiais para o educador ajudá-la a criar e recriar seus próprios conceitos (BRASIL, 1998).

Por meio do brincar as crianças procuram espaços e maneiras de explorar e conhecer o mundo. A partir deste ato elas preparam-se para que futuramente possam ingressar em grupos sociais e estabelecerem contatos com outras pessoas, respeitando regras impostas pela sociedade. Sendo assim, pode-se dizer que a brincadeira favorece o desenvolvimento da criança de uma maneira tão significativa que a criança leva consigo os saberes adquiridos nesta fase por toda sua vida (WAJSKOP, 1995).

Por meio do brincar as crianças interagem com os colegas, se posicionam diante das situações de conflito e desenvolvem maneiras de superá-los, o que é importante para a aquisição de valores futuros, necessários à sua socialização, como aprender a compartilhar, respeitar o outro, respeitar as regras e limites e aprender a conviver em grupo, reconhecendo os limites em relação ao próximo (FRIEDMANN, 2012). Nesse sentido, as crianças necessitam do brincar para evoluir e tornarem-se autônomas, confiantes e criativas, mas como proceder este processo de evolução sem permitir que elas brinquem livremente e criem, por si só, suas próprias regras?

No decorrer de minha prática docente deparei-me com algumas divergências sobre o momento do brincar e isso gerou algumas inquietações, pois não consigo entender como posso proporcionar um processo de evolução nas crianças sem

$$
\sim 64 \sim
$$


permitir que elas também conduzam em determinados momentos o ato de brincar, manifestando sua independência, permitindo-lhes escolher quais brincadeiras e tendo liberdade para elaborar as próprias regras.

Baseado nesta indagação nasceu a ideia de desenvolver um projeto com o objetivo de evidenciar a importância do brincar livremente na Educação Infantil para o desenvolvimento e aprendizagem das crianças. A aplicação do projeto ocorreu em uma sala de Pré II com 24 alunos de uma escola municipal de Vilhena - RO com faixa etária de 4 e 5 anos, em que foram desenvolvidas diversas brincadeiras com envolvimento de todos os alunos.

Assim sendo, neste capítulo enfatizamos que por meio do brincar livremente as crianças procuram espaços e maneiras de explorar e conhecer o mundo. $\mathrm{O}$ ambiente escolar tornar-se um local prazeroso onde o docente ao utilizar-se desta prática passa a obter maior êxito no desenvolvimento das crianças, diante do processo de ensino aprendizagem.

\section{O brincar na educação infantil}

O brincar, na visão de Kishimoto (2010), é uma ação livre, que pode aparecer a qualquer momento, iniciada e conduzida pela criança, a qual desperta "prazer, não exige como condição um produto final; relaxa, envolve, ensina regras, linguagens, desenvolve habilidades e introduz a criança no mundo imaginário" (KISHIMOTO, 2010, p. 1).

Em sentido semelhante, Wajskop (1995) compreende o brincar como uma maneira que as crianças encontram para "interpretar e assimilar o mundo, os objetos, a cultura e as relações e os afetos das pessoas" (WAJSKOP, 1995, p. 66). Para ela, a brincadeira na Educação Infantil possui grande valor no processo de desenvolvimento das crianças, pois

[...] na situação de brincadeira que as crianças podem se colocar desafios para além de seu comportamento diário, levantando hipóteses na tentativa de compreender os problemas que lhes são propostos pelas pessoas e pela realidade com a qual interagem. Quando brincam, ao mesmo tempo que desenvolvem sua imaginação, as crianças podem construir relações reais entre elas e elaborar regras de organização e convivência (WAJSKOP, 1995, p. 67).

Kishimoto (2003, p. 66) também relata que o brincar (juntamente com os jogos) na Educação Infantil é fundamental para formação do conhecimento das crianças, onde as brincadeiras "abrem várias portas para que criança tente resolver problemas e ao mesmo tempo permite que a criança faça planos se projetando para o futuro". De acordo com a pesquisadora: 
A brincadeira significa sociabilizar as regras externas e o mundo adulto, ao qual a criança tem a consciência de que possui pouco poder e pouco pode fazer para mudar isto e ao brincar ela se coloca num papel de poder, em que pode dominar os vilões ou as situações que provocariam medo ou que a faria sentir-se vulnerável e insegura (KISHIMOTO, 2003, p. 66).

Durante o brincar ocorrem muitas descobertas, há desenvolvimento da memória e ampliação da autonomia da criança, ou seja, permite um enriquecer de conhecimentos voltados para a compreensão da sociedade que o cerca (KISHIMOTO, 2010). Kishimoto também nos indica que o brincar é importante para a criança, já que

[...] dá a ela o poder de tomar decisões, expressar sentimentos e valores, conhecer a si, aos outros e o mundo, de repetir ações prazerosas, de partilhar, expressar sua individualidade e identidade por meio de diferentes linguagens, de usar o corpo, os sentidos, os movimentos, de solucionar problemas e criar. Ao brincar, a criança experimenta o poder de explorar o mundo dos objetos, das pessoas, da natureza e da cultura, para compreendê-lo e expressá-lo por meio de variadas linguagens (KISHIMOTO, 2010, p. 1).

Porém, existe uma contradição que se mostra comprometedora do potencial que o brincar oferece à Educação Infantil: brincar de maneira livre x brincar dirigido. Conforme Kishimoto (2010) a pouca qualidade do processo educativo nessa etapa da Educação Básica pode estar relacionada com a dualidade que alguns estabelecem entre essas duas formas de encarar as brincadeiras no ambiente escolar.

O brincar livremente hoje já está ganhando espaço na Educação Infantil, já que é considerado fundamental para fortalecer e enriquecer a cultura infantil e esta percepção vem despertando cada vez mais o olhar reflexivo dos professores e pesquisadores voltados para este tema, pois a função do educador perante as crianças não está fundamentada apenas no ensinar e cuidar, mas também em instigá-las a tornar-se independente (KISHIMOTO, 2010).

Desse modo, o brincar de maneira livre é necessário para ajudá-las a resolverem seus próprios problemas, em que aprenderão a negociar e argumentar. Através do brincar livremente as crianças procuram espaços e maneiras de explorar e conhecer o mundo, expressando-se com mais facilidade, aprendendo a ouvir, concordar ou discordar de determinadas opiniões, exercem liderança e compartilham alegrias e frustrações. Conforme nos apresenta Wajskop:

A criança desenvolve-se pela experiência social, nas interações que estabelece, desde cedo, com a experiência sócio-histórica dos adultos e do mundo por eles criado. Dessa forma, a brincadeira é uma atividade humana na qual as crianças são introduzidas constituindo-se em um modo de assimilar e recriar a experiência sociocultural dos adultos. (WAJSKOP, 2012, p. 31)

De acordo com a autora, a criança recria através das brincadeiras algo do cotidiano de um adulto e diante das brincadeiras, consegue exteriorizar sentimentos 
que não foram resolvidos em seu dia-a-dia, imitando a vida adulta. Através do brincar livremente obtém grandes conquistas, pois este brincar em que as mesmas são as próprias condutoras é fundamental para o preparo da superação dos desafios que encontraram no decorrer das suas vidas. Por meio deste brincar também é possível aprender a controlar seus impulsos, negociar umas com as outras, pois, a docente não faz parte deste momento e não poderá ajuda-las, tendo que resolver suas inquietações sozinhas, neste processo aprendem a tomar conta de suas vidas.

\section{Desenvolvimento do projeto: relato da experiência}

Tenho sete anos de atuação na Educação Infantil e durante toda a minha prática vejo o brincar como algo fundamental para o crescimento emocional, pessoal e intelectual das crianças, seja o brincar dirigido pelo professor ou o brincar livremente. Nunca tive dificuldade em brincar com as crianças, sentar no chão, jogar bola, pular corda, afinal professor de Educação Infantil tem que gostar e estar preparado para este contato mais próximo. Porém, o projeto de intervenção surgiu de minhas indagações relacionadas ao brincar livremente e suas contribuições na aprendizagem das crianças. Durante a aplicação não participei ativamente das brincadeiras, apenas organizei o início da atividade e fiquei na observação.

Ao iniciar o desenvolvimento da intervenção foi apresentado as crianças uma lista contendo inúmeras brincadeiras que já fazem parte do cotidiano da sala e os alunos montaram um cronograma das atividades que ocorreram nas duas semanas de aplicação do projeto. Selecionaram quais brincadeiras queriam realizar primeiro, quais gostavam mais, retiraram as que não queriam e, depois de certo tempo, chegaram a uma listagem elaborada pela turma. Após a escolha das brincadeiras, foi explicado que o brincar seria livre nestas duas semanas e que eles mesmos deveriam se organizar e criar suas próprias normas, a partir de então, interferi o mínimo possível, deixando que as crianças brincassem livremente, criando seus próprios mecanismos sem minha intervenção.

A primeira brincadeira escolhida foi brincar na areia (no parque da escola). Neste dia foi muito gostoso e bastante envolvente, pois as crianças gostam do contato com a areia. Fizeram castelos, bolos para festas de aniversário, construíram casinhas e tiramos inúmeras fotos, de modo que todos participaram.

No segundo dia a brincadeira escolhida foi o Boliche. Para os alunos foi um encanto, afinal até então nunca tínhamos brincado devido à falta de espaço, consequência de obras em realização na escola. Por meio do boliche aprenderam a organizar e ordenar as garrafas na sequência certa. Para isso as garrafas eram numeradas e então tinham que conhecer os números. Em determinados casos, o colega que foi reorganizar não sabia identificar os números e os demais o ajudaram. Teve também três crianças que relataram dificuldades em acertar os pinos devido à 
distância e disseram que a bola não ia na direção certa e, por isso, só perdiam, por isso não gostaram da brincadeira. Porém, todos os demais se saíram bem e queriam repetir no dia seguinte.

No terceiro dia a brincadeira do Ovo-choco foi realizada na quadra da escola. Dois alunos disseram que era complicado correr e tentar acertar o colega, pois ele estava se mexendo e para acertá-lo deveria estar parado. Uma aluna disse que gostou, pois quando corre sente-se alegre e é gostosa essa sensação. De modo geral todos participaram com empolgação.

No quarto dia a brincadeira escolhida foi a Amarelinha. Como esta brincadeira exige noções de espaço e equilíbrio, as crianças precisaram jogar a pedra e também intercalar um pé, dois pés e etc., foi a brincadeira que eles tiveram mais dificuldades, mas como gostam de desafios foi também uma das que mais gostaram e não queriam parar. Os alunos coordenaram bem as regras e as noções de sequência. $\mathrm{Na}$ hora da organização da fila para decidir quem iria pular primeiro e do momento de esperar cada um a sua vez, eles se comportaram a rigor e mostraram mais uma vez que o brincar livremente tem seu potencial, pois se sentem importantes e valorizados por conduzir seu momento de brincar, o que fez com que eles brincassem com mais envolvimento e mais interação.

No quinto dia foi escolhido a Peteca. A turma contava com dois alunos cadeirantes e em todas as brincadeiras sempre dávamos um jeitinho para que eles participassem, contudo nesta brincadeira e na do Ovo-choco foram as que os dois mais se envolveram. Eles ficaram muito felizes por terem a oportunidade de participar com os colegas desses momentos. Outro aluno também disse que gostou muito de brincar no pátio e ter que jogar para o outro colega sem segurar, só batendo. Contudo, teve também uns que disseram: "Nossa professora, que difícil!"; "Batemos ela para cima, mas não sabemos onde cai"; "É difícil, mas é legal!"; "Melhor jogar sozinho!".

No sexto dia a brincadeira foi a Batata Quente. Todos apreciaram, pois envolve músicas e desafios. As crianças relataram que foi muito legal esse dia, mas que se não prestarmos atenção é fácil de perder o jogo, pois a bola acaba ficando nas mãos de quem está desatento.

No sétimo dia foi pular corda. Neste dia eles decidiram que poderiam pular tanto individualmente, quanto ter dois colegas para bater a corda enquanto os demais pulavam. Sendo que eles sozinhos aos poucos iam recriando suas próprias regras. Somente três alunos acharam difícil pular de um lado para o outro, todos os demais se deram bem.

No oitavo dia foi a vez da brincadeira Trilha do Alfabeto. Trata-se de um jogo que utiliza dados e eles jogaram com 4 ou 5 crianças, onde tinham que conduzir o sapo até o final da trilha e quem chegasse primeiro era o vencedor. Foi bastante produtivo, por envolver as letras do alfabeto e os números dos dados exigiu muito 
raciocínio dos alunos e os manteve ainda mais atentos na atividade. Quando o colega tinha dúvidas eles mesmos se acertavam e davam dicas aos outros.

No nono dia desenvolvemos a brincadeira da Cobra Cega. Esta brincadeira envolve agilidade, noção espacial e habilidades para pegar e fugir para não ser capturado, gerando emoções. Duas alunas disseram que não gostaram dessa brincadeira, porque o fato de ficarem com os olhos vendados as incomodou muito.

No décimo e último dia de desenvolvimento do projeto brincamos de Passa Anel e com Massinha de Modelar. A primeira brincadeira envolve controle emocional e há também certa malícia para enganar o outro ao passar ou receber o anel, também exige raciocínio, organização e coordenação. Todos se envolveram e participaram, somente duas crianças disseram que não gostaram, pois acharam muito difícil de chegarem a conclusão de onde estava o anel. Já no momento da Massinha de Modelar, eles se mostraram bastante motivados. Cada um criou as formas desejadas, uns fizeram monstros, outros animais. As meninas, de modo geral, preferiram brincar de casinha e fazer bolos.

\section{Alguns comentários}

Após o desenvolvimento das atividades envolvendo o brincar livremente foi possível obter um diagnóstico do comportamento geral do grupo e também de cada criança individualmente. Durante estes momentos de brincar passamos a conhecer melhor as crianças, pois nestes instantes agiram com espontaneidade. A análise também permitiu identificar qual o nível de desenvolvimento delas, quais seus interesses, necessidades e seus possíveis conflitos, tendo em vista que "na atividade de brincar, as crianças vão construindo a consciência da realidade ao mesmo tempo em que já vivenciam uma possibilidade de modificá-la" (WAJSKOP, 1995, p. 67).

Este projeto também foi importante ao aproximar as crianças umas das outras e as manterem motivadas dentro do ambiente escolar. Mostrou a importância da mudança, de deixar de lado aquelas práticas repetitivas e inovar no fazer pedagógico com as crianças, deixando de dar aquela aula totalmente dirigida e permitir que elas também demonstrem seus conhecimentos, visando tornar o ambiente escolar acolhedor, alegre e, desse modo, fortalecer os laços entre docente e alunos.

Os momentos pós-brincadeiras também merecem destaque. Foram bastante produtivos. Ao final de cada dia sentávamos para roda de conversa e ali todos relatavam o que gostaram, do que não pretendiam mais brincar, o que queriam repetir e o que aprenderam com as brincadeiras.

Ao término do projeto pude constatar que o brincar livremente além de ser um momento divertido, é um método válido de aprendizagem, uma vez que permite à criança adquirir conhecimentos e fazer reflexões, dando à elas liberdade de criação, 
através da qual as crianças demonstram suas emoções e pensamentos sobre o mundo e interagem consigo e com os demais. Ficou claro que o brincar livremente além de ser um momento fundamental para observar as crianças é também prazeroso. Possibilita a elas escolherem como irão brincar, quanto tempo durará a brincadeira e quais são suas próprias regras. Neste momento tornam-se mais autônomos, desenvolvem a criatividade e aprendem de maneira envolvente e significativa.

\section{Considerações finais}

Esta experiência foi um processo dinâmico com enormes possibilidades de crescimento. Enquanto desenvolvia-se o projeto foi possível refletir sobre a prática pedagógica, visando repensar acerca das condições sobre o processo de ensino e aprendizagem. O que está bom e o que tem necessidade de mudança, afinal devemos estar em constante transformação.

No dia a dia escolar geralmente brincamos e participamos junto, mas nos quinze dias da aplicação do projeto não foi assim. Uma das maiores contribuições para a prática pedagógica foi evidenciar que o brincar livremente é tão importante quanto o brincar dirigido pelo professor, pois auxilia na formação de crianças mais seguras e autônomas, influenciando também na prática enquanto professora, uma vez que ainda tínhamos uma visão de que devíamos levar tudo já preparado.

Este projeto veio para me ajudar a resolver meus conflitos e constatar que ambas as práticas devem caminhar juntas, pois uma é o complemento da outra. Se sempre oferecermos o brincar dirigido, a criança não adquire autonomia para criar suas próprias regras e conduzir todos os momentos das brincadeiras. Isso é concernente ao que nos diz Kishimoto, ao enfatizar que é preciso desconstruir essa visão dualista equivocada em relação ao brincar para "pensar na criança inteira, que, em sua subjetividade, aproveita a liberdade que tem para escolher um brinquedo para brincar e a mediação do adulto ou de outra criança, para aprender novas brincadeiras" (KISHIMOTO, 2010, p. 1).

\section{Referências}

BRASIL. Ministério da Educação e do Desporto. Secretaria de Educação Fundamental. Referencial Curricular Nacional para a Educação Infantil. Ministério da Educação e do Desporto, Secretaria de Educação Fundamental. Brasília: MEC/SEF, 1998.

FRIEDMANN, A. O Brincar na Educação Infantil: observação, adequação e inclusão. São Paulo: Moderna, 2012. 
KISHIMOTO, T. M. Jogos infantis: o jogo, a criança e a educação. Petrópolis, RJ: Vozes, 2003.

. Brinquedos e Brincadeiras na Educação Infantil. In: I Seminário Nacional: Currículo em Movimento - Perspectivas Atuais. Belo Horizonte, novembro de 2010.

WAJSKOP, G. O brincar na educação infantil. Cadernos de Pesquisa, n. 92, p. 6269, fev. 1995.

Brincar na Educação Infantil: uma história que se repete. 9. ed. São Paulo: Cortez Editora, 2012. 


\section{Brincadeiras na escola de educação infantil: um estudo em Porto Velho/RO}

Janís Hilário Barroso

Juracy Machado Pacífico

\section{Introdução}

Este texto apresenta resultados de um estudo que objetivou investigar a presença das brincadeiras na prática pedagógica da professora de Educação Infantil que trabalha com crianças de 4 e 5 anos, no sentido de apreender de que forma a professora insere brincadeiras em seu planejamento e quais recursos são utilizados em situações de brincadeira no espaço escolar.

O estudo foi desenvolvido em uma escola de Educação Infantil e partiu do princípio de que, a professora, principal responsável pelas situações promotoras de desenvolvimento e aprendizagem em âmbito escolar necessita saber o valor da brincadeira para o desenvolvimento da criança. No caso da Educação Infantil, os estudos, que serão apontados mais adiante, indicam que é necessário oferecer um espaço que combine brincadeiras que envolvam experiências das crianças, um ambiente favorável que proporcione alegria, prazer, criatividade, inventividade e movimentos no ato de brincar.

\section{As brincadeiras na educação infantil: espaços e interações}

Sarmento (2007) analisa, a partir de estudos de outros autores, principalmente de Ariès (2006), que até a Idade Média, as crianças pequenas não tinham função social bem definida e a taxa de mortalidade infantil era muito alta. Havia grande exploração do trabalho infantil e as crianças pobres não trabalhavam com o adulto, em várias atividades. Já as crianças nobres tinham seus educadores e 
eram vistas como adultos em miniatura, sendo o momento da infância considerado somente como uma preparação para a vida adulta. Segundo o autor,

As concepções construídas historicamente sobre a infância, baseadas numa perspectiva adultocêntrica, tanto esclarecem como ocultam a realidade social e cultural das crianças, sendo portanto, necessária a ruptura com o modelo epistemológico sobre a infância até então instituídos.

(SARMENTO, 2007, p. 26).

No século XVIII Rousseau, em seu livro Emílio ou da Educação, coloca-se contra essa visão de criança como adulto em miniatura e defende a especificidade infantil, a criança como detentora de uma natureza própria que deve ser desenvolvida.

Essa perspectiva contribuiu para que a sociedade iniciasse um processo de valorização da moral, da saúde e do bem comum da criança. Com isso, a educação para essa faixa etária passa a ser diferenciada, sendo que a necessidade de brincar passava a ser respeitada pela sociedade e vista como uma possibilidade de educála. Começam a ser elaboradas alternativas que visavam 0 cuidado com 0 desenvolvimento infantil (WAJSKOP, 1999).

Segundo autores como Wajskop (1999) e Kishimoto (1996), educadores como Frederich Froebel (1782-1852), Maria Montessori (1870-1909) e Ovide Decroly (1871-1932), influenciados pela filosofia de sua época, romperam com a educação verbal e tradicionalista e colaboraram com uma educação própria para as crianças pequenas, com a utilização de materiais didáticos apropriados, na perspectiva de uma educação natural. Referindo-se ainda aos três educadores, Kishimoto (1996) afirma que Froebel, Montessori e Decroly contribuíram para a superação de uma concepção tradicionalista de ensino, inaugurando um período histórico no qual as crianças passaram a ser compreendidas enquanto seres ativos e criativos.

Bassedas, Huguet e Solé (1999) fundamentam suas ideias em Vigotski e destacam que o desenvolvimento da criança (nascida) se inicia no momento em que nasce e perdura por toda a sua vida. Ressaltam que de zero a seis anos ocorre um processo bem complexo, que não se repetirá durante seu desenvolvimento futuro. Ao nascer as crianças necessitam de cuidados mínimos e são extremamente dependentes dos adultos. À medida que crescem aumenta a complexidade de suas demandas (choram por mal-estar, por não querer ficar sozinhas ou querer outra companhia, etc.); aumenta sua capacidade de resposta - escolhas, vontades, começam, a partir da linguagem, a pedir o que querem; etc.

Conforme as autoras (BASSEDAS, HUGUET E SOLÉ, 1999), o desenvolvimento da criança, portanto, ocorre através da interação e envolve a contribuição de processos hereditários, genéticos, maturacionais, bioquímicos, processos de estimulação ambiental e aprendizagem. Assim, o desenvolvimento do ser humano dá-se pelo resultado de uma interação entre maturação (geneticamente) e a estimulação social, cultural e pessoal que a criança recebe das pessoas que a 
cuida e educa. Os aspectos psicológicos de desenvolvimento não estão predeterminados, mas são adquiridos mediante a interação com o meio físico, social e cultural.

Bassedas, Huguet e Solé (1999) destacam ainda que as crianças aprendem comportamentos, destrezas, hábitos e conhecimentos de maneiras variadas. Sendo assim, a aprendizagem pode ocorrer através da experiência com os objetos, através da experiência em determinadas situações, aprendizagem por imitação e aprendizagem pela formação de andaimes por parte da pessoa adulta ou outra pessoa mais capaz, mas principalmente, pela interação.

Nesse sentido podemos dizer que as crianças (e qualquer ser humano) aprendem e desenvolvem suas capacidades: partindo do que já sabem, ou seja, sobre a base do que já possui - suas experiências pessoais e culturias - e isso supõe uma reconstrução pessoal de um conhecimento preexistente; aprendem refletindo sobre o objeto de conhecimento, em um processo de revisão e modificação de esquemas, processo esse que teve início a partir de um desequilíbrio causado pelo contado com o novo; apoiando-se em capacidades e competências já dominadas para adquirir outras; atualizando seus esquemas de conhecimentos, no sentido de comparar o que sabe com o que é novo; identificando semelhanças e diferenças; comprovando resultados. Aprendem quando há conflito cognitivo, de maneira que todo esse processo que envolve mover-se sobre as coisas e sobre o objeto de conhecimento para explorá-lo e apreendê-lo possibilita mais e mais o seu desenvolvimento integral, amplo e em diferentes perspectivas.

Observa-se que os diferentes caminhos que temos e que as crianças têm para se desenvolverem e aprender não se apresentam isoladamente, mas no decorrer das atividades cotidianas, momento em que participam de diversas situações ocasionais ou planejadas, onde essas diversas maneiras estarão presentes individualmente ou ao mesmo tempo. Nesse contexto de interações, a brincadeira ocupa o maior tempo, uma vez que é a principal atividade da criança.

Kishimoto (2010, p. 1) destaca:

O brincar é uma ação livre, que surge a qualquer hora, iniciada e conduzida pela criança, dá prazer, não exige, como condição, um produto final, relaxa, envolve, ensina regras, linguagens, desenvolve habilidades, e introduz no mundo imaginário. [...] considera-se todo o período da educação infantil como importante para a introdução das brincadeiras. (KISHIMOTO, 2010, p. 1).

No ato de brincar relacionam-se dois elementos importantes: a brincadeira e o brinquedo. O brinquedo é um objeto utilizado durante as brincadeiras. É um objeto facilitador do desenvolvimento das atividades lúdicas, que desperta a curiosidade, exercita a inteligência, permite a imaginação e a invenção. Como menciona 
Kishimoto (1996, p. 48), a palavra "brinquedo" não deve ser restrita à pluralidade de sentido dos jogos, pois conota crianças e tem uma dimensão material, cultural e técnica. Enquanto objeto, é sempre suporte de brincadeira. E a brincadeira nada mais é do que a ação que a criança desenvolve ao realizar as regras do jogo, ao mergulhar na ação lúdica. Destaca a autora que "Hoje, a imagem de infância é enriquecida também com o auxílio de concepções pedagógicas, que reconhecem o papel de brinquedos e brincadeiras no desenvolvimento e na construção do conhecimento infantil".

Brougère (1989 apud KISHIMOTO, 1996) entende que a brincadeira é uma mutação do sentido da realidade, pois na brincadeira algumas coisas transformamse em outras. Por isso é um espaço à margem da vida cotidiana, que obedece regras criadas pela circunstância. Os objetos podem apresentar-se, conforme o autor, com significados diferentes daquele que possuem normalmente.

Brincadeiras, segundo Waskop (1999, p. 25), "é uma atividade humana na qual as crianças são introduzidas constituindo-se em um modo de assimilar e recriar a experiência sociocultural dos adultos". Diante disso, na brincadeira as crianças podem pensar e explorar situações novas ou do seu cotidiano em relação o mundo que as rodeia. Vale resaltar que o brincar e interagir na educação infantil são colocados como eixos norteadores definidos no artigo $9^{\circ}$ das Diretrizes Curriculares Nacionais para a Educação Infantil (DCNEI) (BRASIL, 2009).

Brincar, portanto, leva à interação que, na infância, acontece com os sujeitos, objetos e espaços, mediada pelas próprias brincadeiras, pelas experiências que as crianças vão vivenciando, pela cultura na qual já nascem inseridas e ainda, por meio da cultura cotidianamente produzida por seus pares e por elas mesmas.

Os mobiliários, como mesas, cadeiras e outros, devem estar de acordo com as estaturas da criança que possa assim facilitar a interação quando estiver em sala de aula. $\mathrm{O}$ ambiente deve permitir o deslocamento das crianças de forma livre, e, principalmente, que os materiais estejam ao seu alcance. As paredes devem ter cores claras, pois isso além de clarear o ambiente, passa tranquilidade para as crianças.

A rotina da escola tem que ser flexível e a professora precisa explorar os espaços da sala para que haja estimulação mediante as interações e criar atividades complementares para garantir a autonomia do ritmo de cada criança.

A escola hoje pode preparar um espaço onde a criança possa brincar e ter acesso a uma diversidade de brinquedos educativos. Este espaço deve ser convidativo estimulando-a a explorar, sentir, experimentar, e se divertir, pois na Educação Infantil o espaço e os materiais são parte do currículo, pois assumem nessa etapa da educação básica um lugar necessário. 


\section{Onde estão as brincadeiras na educação infantil? Os sentidos atribuídos e a realidade de sala de aula}

Considerando a questão problematizadora colocada, este trabalho foi desenvolvido com o objetivo de investigar como a professora de educação Infantil trabalha as brincadeiras em seu cotidiano escolar e, considerando o objeto de estudo, foi desenvolvido a partir de uma abordagem qualitativa, com aplicação de questionário, com perguntas abertas, para três professoras, aqui denominadas de Professora A, Professora B e Professora C, todas de uma escola de educação infantil. Todas possuem graduação em Pedagogia e pós-graduação. Duas das professoras fizeram pós-graduação na área de Gestão, Supervisão e Orientação Escolar e uma delas em Psicopedagogia. Porém, ter formação em graduação, licenciatura garante a promoção de uma educação de qualidade para as crianças da primeira etapa da educação básica?

Entendemos que indiscutivelmente contribui, mas não é tudo. É preciso que as professoras tenham um trabalho constante de planejamento e estudo para que sua prática seja significativa para as crianças e até mesmo para ela própria.

A observação foi realizada em sala de aula, com crianças de quatro anos (Pré-Escola) durante cinco dias consecutivos, no período da manhã, com registros realizados no Caderno de Campo. Os sujeitos participantes foram, ao todo, quatro professoras, sendo três professoras que responderam ao questionário e uma professora na qual a observação em sala foi realizada.

Ao falar de brincadeiras na Educação Infantil, não pensamos que necessariamente precisam ser ensinadas, pois o brincar é uma ação que ocorre de forma natural, já que desde bebê as crianças brincam. No entanto, as crianças também aprendem a brincar, pois também as brincadeiras estão presentes na diversidade cultural da sociedade. Assim, a professora precisa planejar e organizar situações para que as brincadeiras ocorram de maneira diversificada, propiciando às crianças interações que permitem participar dos temas, papéis, objetos, dialogar e interagir com os colegas com quem brincam.

Oliveira (1992) destaca que o educador pode desempenhar um importante papel no transcorrer das brincadeiras se consegue discernir os momentos em que deve só observar, em que deve intervir na coordenação da brincadeira, ou em que deve integrar-se como participantes das mesmas. Para educar é preciso ter uma ideia clara sobre quem são as crianças e sobre o que é relevante para a sua educação. Considerar que todas as crianças são cidadãs, com direito a uma educação de qualidade e que podem ser educadas por meio de brincadeiras e a partir das interações é o primeiro passo. 


\section{- Os sentidos atribuídos pelas professoras às brincadeiras na Educação Infantil}

A partir da observação e dos dados levantados utilizando-se da aplicação de questionários, organizamos uma descrição da realidade do brincar em escolas de Educação Infantil do município de Porto Velho. Os questionários foram importantes para a coleta de dados sobre os sentidos atribuídos ao brincar pelas professoras. Colocamos para as professoras várias questões que rementem a pensar as brincadeiras na Educação Infantil para que escrevessem sobre, colocando os sentidos que atribuem ao brincar. Ao serem perguntadas sobre a importância das brincadeiras na Educação Infantil, narraram:

Quadro 1 - Importância das brincadeiras na sala de aula.

\begin{tabular}{|c|l|}
\hline Professora & \multicolumn{1}{c|}{ Respostas } \\
\hline A & $\begin{array}{l}\text { Sim. Não concordo que seja todos os dias, pelo menos duas vezes na } \\
\text { semana estimula mais a criança a frequentar a escola a fazer as atividades } \\
\text { na educação infantil. Creio que as brincadeiras sejam estimulantes, pois são } \\
\text { muito pequenas essas crianças e, ainda mais de periferia! }\end{array}$ \\
\hline B & $\begin{array}{l}\text { Com certeza a criança precisa aprender brincando. Assim ela vai mostrar } \\
\text { interesse para voltar a escola. }\end{array}$ \\
\hline C & $\begin{array}{l}\text { Sim. Além de proporcionar diversão, deve ser um recurso utilizado para } \\
\text { promover a aprendizagem. }\end{array}$ \\
\hline
\end{tabular}

Fonte: Questionário aplicado em dezembro de 2013.

Observando-se a concepção das professoras sobre as brincadeiras em sala de aula, vimos que todas acreditam ser importante a presença das brincadeiras na etapa da educação infantil, mas a consideram como motivação para aprender conteúdos escolares. Assim, as brincadeiras são consideradas estimulantes e está subentendido na fala de todas que a brincadeira serve para ajudar a criança a aprender. Uma delas chega a citar a necessidade da brincadeira, principalmente para as crianças da periferia. Consideramos que, de fato, a brincadeira estimula a criatividade, o desenvolvimento intelectual, o desenvolvimento motor, mas isso é para todas as crianças e não somente para os pobres. As crianças de periferia também têm acesso a brincadeiras, também brincam, às vezes até mais que as crianças de classe média ou alta. Para Kishimoto (2010, p. 1), "[...] sua importância se relaciona com a cultura da infância que coloca a brincadeira como a ferramenta para a criança se expressar, aprender e se desenvolver". 
Mas as professoras também concebem a brincadeira como um motivador para a criança ter vontade de voltar à escola. Certamente a possibilidade de brincar em espaços coletivos contribui para que a criança goste da escola, mas o principal é que brincar possibilita às crianças desenvolverem-se integralmente os aspectos físicos, motores, emocionais, cognitivos e, principalmente, a criatividade e a capacidade de resolver problemas.

Outra professora ressalta que a brincadeira também é recurso para a aprendizagem. No final das contas, pensam a brincadeira com um fim outro que não o lúdico, o da diversão, da criação, da fantasia, da internalização da cultura de modo mais leve e representativo. Mas pelo contrário, sempre consideram a brincadeira para levar a criança à aceitação da escolarização tradicional, da aprendizagem dos conteúdos científicos, ou seja, a brincadeira como um meio e não com um fim em si mesmo. Não deixa de ser importante, mas na Educação Infantil o brinca é o eixo central.

Sobre a frequência com que inserem as brincadeiras nas atividades de sala de aula, as professoras responderam o que segue no quadro 2:

Quadro 2 - Frequência das brincadeiras em sala de aula

\begin{tabular}{|c|l|}
\hline Professora & \multicolumn{1}{c|}{ Respostas } \\
\hline A & $\begin{array}{l}\text { Na minha turma temos um dia só para recreação, outro dia é o vídeo. Eles } \\
\text { brincam em sala de aula, pois nossa escola é anexo e não tem cobertura; o } \\
\text { sol é muito quente quando não, é a chuva. }\end{array}$ \\
\hline B & $\begin{array}{l}\text { Os jogos e brincadeiras são rotina na sala de aula ou no espaço externo da } \\
\text { escola. A cada dia da semana há uma programação a ser desenvolvida. }\end{array}$ \\
\hline C & $\begin{array}{l}\text { São inseridos como fixação do conteúdo ensinado e são usados pelo menos } \\
\text { duas vezes na semana. }\end{array}$ \\
\hline
\end{tabular}

Fonte: Questionário aplicado em dezembro de 2013.

Observamos que o espaço físico da escola também é um limitador das brincadeiras. Se não há espaços adequados, as possibilidades de desenvolvimento diversificado também ficam impossibilitadas. A professora $C$ considera que brincadeiras são necessárias para fixação de conteúdos, o que é totalmente contrário ao disposto nas DCNEI de 2009, que explicita que as brincadeiras são primordiais para o processo de desenvolvimento integral da criança. Sobre isso, em texto produzido para o Ministério da Educação, Kishimoto (2010, p. 1) explica que

[...] o brincar é a atividade principal do dia a dia. É importante porque dá o poder à criança para tomar decisões, expressar sentimentos e valores, 
conhecer a si, os outros e o mundo, repetir ações prazerosas, partilhar brincadeiras com o outro, expressar sua individualidade e identidade, explorar o mundo dos objetos, das pessoas, da natureza e da cultura para compreendê-lo, usar o corpo, os sentidos, os movimentos, as várias linguagens para experimentar situações que Ihe chamam a atenção, solucionar problemas e criar. Mas é no plano da imaginação que o brincar se destaca pela mobilização dos significados.

Também para a autora, a criança não nasce sabendo brincar com todas as possibilidades dessa prática, pois por mais que brinque o tempo todo ela também aprende a brincar na interação com outras crianças. Em relação à construção de capacidades e conhecimento, as professoras também atribuem um sentido muito específico à brincadeira, conforme quadro 3 :

Quadro 3 - Brincadeiras e a construção do conhecimento

\begin{tabular}{|c|l|}
\hline Professora & \multicolumn{1}{|c|}{ Respostas } \\
\hline A & $\begin{array}{l}\text { Sim. A lateralidade, equilíbrio, socialização, união bons modos, pois } \\
\text { algumas vem com um palavreado que temos que corrigir. }\end{array}$ \\
\hline B & $\begin{array}{l}\text { Construção de regras, comunicação e expressão, raciocínio, lateralidade, } \\
\text { coordenação motora ampla e fina, cuidados com o corpo, compartilhar e } \\
\text { dividir, cuidados com o meio ambiente, estimula concentração percepção e } \\
\text { outros. }\end{array}$ \\
\hline C & $\begin{array}{l}\text { Coordenação motora, lateralidade, psicomotrocidade, coordenação } \\
\text { visomotora, socialização, criatividade }\end{array}$ \\
\hline
\end{tabular}

Fonte: Questionário aplicado em dezembro de 2013.

Observa-se que as professoras consideram as brincadeiras como importante componente na construção do conhecimento da criança de 4 e 5 anos, e dentre as mais usuais, que segundo elas levariam ao desenvolvimento de habilidades e aprendizagem, estão as atividades que envolvem a lateralidade, coordenação motora, socialização e a linguagem. Quanto a isso, de fato as brincadeiras têm um papel fundamental para o desenvolvimento de todos essas habilidades $\mathrm{e}$ competências. Vejamos as demais questões.

Quando questionadas sobre as brincadeiras que fazem parte do cotidiano de suas atividades na Educação Infantil, vimos uma diversidade: 
Quadro 4 - Brincadeira presentes e que as crianças mais gostam:

\begin{tabular}{|c|l|}
\hline Professora & \multicolumn{1}{|c|}{ Respostas } \\
\hline A & $\begin{array}{l}\text { Presentes: Danças, massinhas, blocos de montar, músicas, utilizamos } \\
\text { alguns bem poucos recursos oferecidos pela SEMED. } \\
\text { Gostam: Dança da cadeira, morto vivo, Rodinhas de músicas. }\end{array}$ \\
\hline B & $\begin{array}{l}\text { Presentes: Ciranda de roda de conversa roda de leitura, teatro, } \\
\text { apreciação musical, jogos diversos numéricos e letrados, amarelinha, } \\
\text { pula corda, desenho, pintura modelagem recorte colagem quebra- } \\
\text { cabeças e faz de conta, dança da cadeira e outros. } \\
\text { Gostam: Ciranda de roda de leitura, teatro, apreciação musical, desenho, } \\
\text { pintura, modelagem recorte e colagem, quebra-cabeça. }\end{array}$ \\
\hline C & $\begin{array}{l}\text { Presentes: Vivo morto, serra-serra, serrador, carrocinha de picolé, } \\
\text { Brincadeiras de roda amarelinha, boliche. } \\
\text { Gostam: Vivo morto, boliche, carrinho de picolé. }\end{array}$ \\
\hline
\end{tabular}

Fonte: Questionário aplicado em dezembro de 2013.

O quadro acima nos leva a algumas inferências. Há de fato uma diversidade de brincadeiras citadas como presentes na escola, nas turmas de educação infantil. No entanto, o que se percebe é que muitas delas são sempre brincadeiras tradicionais e que muitas vezes são realizadas aleatoriamente, sem o acompanhamento docente, ou seja, são realizadas somente nos momentos coletivos. Juntando essas informações com nossas observações, diríamos que somente as músicas são realizadas junto com as professoras.

Os dados nos mostram que todas as professoras acreditam ser importante trabalhar brincadeiras na etapa da educação infantil, mas é preciso considerar que a professora precisa pensar a brincadeira, planejá-la também. Observamos que as brincadeiras acontecem, mas com pouca frequência. Mas é interessante observar que as professoras não fazem referência ao fato de que as crianças dessa idade precisam basicamente disso e a escola tem a função de possibilitar com que as experiências das crianças integrem a proposta curricular. Ficamos com uma questão: se as professoras sabem, conhecem os objetivos da brincadeira na préescola, as mesmas consideram isso em suas práticas pedagógicas? 


\subsection{Atribuir sentidos e viver os sentidos atribuídos: onde estão as brincadeiras na prática da professora?}

As observações nos possibilitaram um olhar sobre a realidade escolar e o que vimos não foi o que desejaríamos ter visto. Fizemos registros a cada observação e os organizamos conforme aconteciam durante o dia letivo.

\section{Episódio 1 (09/12/13 - Segunda-feira): Onde está a brincadeira?}

\section{Que pena! Não esteve lá...}

Na chegada, 13h30min, as crianças deixam sua bolsa na sala de aula, voltam para fazer a fila; é feita uma oração (prática aparentemente familiar às crianças) e todos retornam para sala de aula. É liberado para tomar água e ir ao banheiro; é passada uma atividade que, nesse dia foi uma leitura da estória dos três porquinhos; depois da leitura foram feitas algumas perguntas em relação ao texto. A professora participou da atividade fazendo algumas interpretações. Em seguida foi passado um desenho para que pintassem em relação a leitura dos três porquinhos. Chega o momento do lanche, e do recreio. Nessa hora todos ficam muito alegres e é evidente o grau de satisfação nesse momento e imediatamente formam grupos: um só de meninas e outro só de meninos e em ambos os grupos sempre tem um líder. Após o lanche, como estavam na última semana de aula, eles estavam ensaiando para coral na festinha de natal. Foi disponibilizado esse segundo momento para o ensaio e todos participaram. As crianças saíram às $17 \mathrm{~h} 30 \mathrm{~min}$.

\section{Episódio 2 (10/12/13 - Terça-feira): Onde está a brincadeira?}

O segundo dia segue a rotina do primeiro dia até o retorno para a sala de aula; as crianças são liberadas para tomar água e ir ao banheiro; em especial nesse dia as crianças são autorizadas para atividades de jogos, recreação e brinquedos. Primeiro foi desenvolvida a atividade sobre o numeral 8, onde a professora explicou que era para escrever o numeral 8 e pintá-lo; todos realizaram. Chegada a hora do lanche e recreio: todos brincam; em segundo momento foram desenvolvidas atividades que envolveram brincadeiras (montagem de blocos, música, massinhas). Nesse dia as crianças poderiam levar brinquedos de suas casas para a sala de aula. Foi feito o ensaio da música para o coral. As crianças saíram às 17h30min.

\section{Episódio 3 (11/12/13 - Quarta-feira): Onde está a brincadeira?}

No terceiro dia, da mesma forma: chegada, 13h30min; as crianças deixam sua bolsa na sala de aula, voltam para fazer a fila; é feita a oração e todos retornam para sala de aula; é liberado para tomar água e ir ao banheiro; nesse dia são levadas para sala de vídeo (assistem desenhos animados: pica-pau e galinha pintadinha). É uma alegria quando a professor coloca o DVD da galinha pintadinha todos começam a acompanhar as músicas e a dançarem. Alegria! Alegria! Hora do lanche e recreio são brincadeiras livres. No segundo momento foi feita uma atividade do alfabeto 
através de figuras, pronúncias coletivas e individuais. Ensaio da música da festinha de natal. As crianças saíram às $17 \mathrm{~h} 30 \mathrm{~min}$.

\section{Episódio 4 (12/12/13 - Quinta-feira): Onde está a brincadeira?}

\section{Esteve por perto...}

No quarto dia (12/12/13, quinta-feira) estava chovendo. Como não há quadra fechada na escola, as crianças foram direto para a sala de aula, fizeram a oração. Nesse dia foi feita uma atividade sobre os nomes próprios, escrita de seus nomes com letrinhas cursivas, mas nem todos conseguiram. A professora nesse dia levou uma caixinha de som, colocando várias músicas, como som ambiente algumas crianças acompanhavam; depois a professora pediu que algumas crianças cantassem: ela parava a música, a criança tinha que acompanhar. As crianças saíram às 17h30min.

Reconhecemos que o tempo de observação não nos permite tirar muitas conclusões, mas o conteúdo dos registros nos dão pistas de que lugar ocupam as brincadeiras em sala de aula. E, à pergunta, "Onde estão as brincadeiras?", vimos que durante a semana os episódios de brincadeiras foram poucos. Também ficou explícito que as atividades programadas pela professora que envolveram brincadeiras foram escassas. O que podemos chamar de brincadeiras ocorreram em três episódios, mas nos pareceu, pela experiência em observação por ocasião do acompanhamento das práticas em estágio supervisionado, que o que geralmente se faz e que são sempre muito repetitivas, são atividades de jogos, recreação (livre e no horário do intervalo) e brinquedos - montagem de blocos, música, massinhas. De fato, as crianças adoram massinhas de modelar, mas fazem sempre as mesmas coisas: enrolam, embolam, jogam nos colegas, mas não há uma orientação para que usem a imaginação e criatividade com esse material.

A sala de vídeo também é outro espaço que, quando a escola tem, é muito disputada. Lá as crianças fazem o que geralmente já fazem em casa, mas é o que ainda as diverte, pois sempre há a presença de música e dança. No quarto dia de observação, dia chuvoso, as crianças ouvem músicas e contam dentro de sala. Isso também é importante, mas vimos que as crianças não estavam tão atentas e interessadas pela atividade. É na brincadeira que a criança tem a liberdade para tomar decisões:

[...] expressar sentimentos e valores, conhecer a si, os outros e o mundo, repetir ações prazerosas, partilhar brincadeiras com o outro, expressar sua individualidade e identidade, explorar o mundo dos objetos, das pessoas, da natureza e da cultura para compreendê-lo, usar o corpo, os sentidos, os movimentos, as várias linguagens para experimentar situações que the chamam a atenção, solucionar problemas e criar. Mas é no plano da imaginação que o brincar se destaca pela mobilização dos significados (KISHIMOTO, 2010, p. 1).

E por fim, é na brincadeira, que a criança começa a se descobrir e aprende a aceitar o outro, organizando assim, suas relações emocionais e formando relações sociais. 


\section{Considerações finais}

O estudo nos leva a corroborar o que aponta Kishimoto (2010, p. 3) que a interação entre criança e ambiente é algo que precisa ser considerado na organização do ambiente. "A organização do ambiente facilita ou dificulta a realização das brincadeiras e das interações entre as crianças e adultos. $O$ ambiente físico reflete as concepções que a instituição assume para educar a criança."

Os dados obtidos nos mostraram que as professoras acreditam ser importante trabalhar brincadeiras na etapa da educação infantil, mas usam as brincadeiras como ferramentas em sala de aula. As brincadeiras ainda são trazidas pelas professoras com fins didáticos para o ensino dos conteúdos, o que desvirtua o que se espera das brincadeiras.

Observou-se também que as professoras que trabalham diretamente com as crianças percebem que o brincar proporciona progressos e avanços em seu desenvolvimento. No entanto, vimos de perto a pobreza de espaços, as limitações impostas em dias tranquilos, inclusive. Quando algo foge à rotina, fica ainda mais difícil a atividade com brinquedos e brincadeiras. Registramos também que outro limitador da criatividade das crianças, além dos espaços físicos, é a ausência de brinquedos nas salas de aula e na escola de modo geral. As interações possibilitadas pelas brincadeiras ficam restritas.

De modo geral vimos que as brincadeiras ocupam um espaço na prática pedagógica da professora de Educação Infantil, no trabalho com crianças de préescola, mas esse lugar não é o principal. Considerando as respostas e também os dias de observação, vimos que as brincadeiras estão um pouco distantes do dia-adia escolar. As crianças brincam, mas não que esse brincar não nos pareceu resultante de um planejamento das professoras. Elas consideram, sim, as brincadeiras, mas geralmente para utilização com uma finalidade pedagógica no trabalho com os conteúdos científicos.

Abordar essa questão é, sem dúvida, algo necessário, pois mesmo com pesquisas e práticas largamente divulgadas, o cotidiano da escola continua a limitar e até coibir o brincar e tudo o que com essa prática as crianças podem conquistar rumo à construção de sua identidade e de suas capacidades.

\section{Referências}

ARIĖS, Philippe. História social da criança e da família. Trad. Dora Flaksman. 2 ed. Rio de Janeiro: LTC, 2006. 
BASSEDAS, Eulália; HUGUET, Teresa; SOLÉ, Isabel. Trad. Cristina Maria de Oliveira. Aprender e Ensinar na Educação Infantil. Porto Alegre: Artes Médias Sul, 1999.

BRASIL. Congresso Nacional. Constituição da República Federativa do Brasil. Brasília: Senado Federal, Centro Gráfico, 1988.

BRASIL. Congresso Nacional. Emenda Constitucional 59/2009. Brasília: Senado Federal, Centro Gráfico, 2009a.

BRASIL. Congresso Nacional. Lei de Diretrizes e Bases da Educação Nacional $\mathbf{n}^{\circ}$ 9394/96. Brasília: Senado Federal, Centro Gráfico, 1996.

BRASIL. Congresso Nacional. Parecer do CEB/CNE n²0/2009. Brasília: Senado Federal, Centro Gráfico, 2009c.

BRASIL. Ministério da Educação. Conselho Nacional de Educação. Parâmetros Nacionais de Qualidade para a educação infantil. Brasília: 2006. (Volume I).

BRASIL. Ministério da Educação. Resolução n. 5, de 17 de dezembro de 2009. Fixa as Diretrizes Curriculares Nacionais para a Educação Infantil. Brasília: 2009b.

KISHIMOTO, Tizuko Morchida. Jogo, Brinquedo, Brincadeira e a Educação. São Paulo: Cortez, 1996.

Brinquedos e brincadeiras na Educação Infantil. Consulta pública. Anais Do I Seminário Nacional: Currículo em Movimento. Belo Horizonte: Perspectivas Atuais, 2010.

OLIVEIRA, Zilma de Moraes Ramos de. A natureza do ensino segundo uma perspectiva sociointeracionista. In: Revista da Associação Nacional da Educação. $\mathrm{N}^{\circ}$ 18, ano II, 1992.

PIAGET, Jean. A formação do símbolo na criança: imitação, jogo e sonho, imagem e representação. Rio de Janeiro: LCT, 1971.

RAVENA, Cassia Mulin de Assis Medel. Educação Infantil a Construção do Ambiente às Práticas Pedagógicas. Rio de Janeiro: Vozes, 2011.

SARMENTO, M.J. (orgs). Infância (in)visível. Araraquara, São Paulo: Junqueira\& Marin, 2007.

VYGOTSKI, L. S. A formação social da mente. 4. ed. São Paulo: Martins Fontes, 1991

WAJSKOP, Gisela. Brincar na Pré-Escola. 3. ed. São Paulo: Cortez, 1999. 
WINNICOTT, D. W. A criança e o seu mundo. 6 ed. Rio de Janeiro: LTC- Livros Técnicos e Científicos Editora S.A., 1982. 


\section{Memórias, experiências escolares e reflexão das práticas de leitura na educação infantil}

Denise Franco Dalla Rosa

Deusodete Rita da Silva Aimi

\section{Introdução}

Apresentamos neste capítulo memórias do início da escolarização, as primeiras experiências com a sala de aula no papel de ajudante e estagiária de instituições escolares, as reflexões das práticas já realizadas com os alunos e a elaboração do projeto chamado Práticas de Leituras na Educação Infantil, destacando $o$ ato de ler para as crianças, baseado em teorias de renomados autores que descrevem a importância de realizar leituras para os alunos. No início da vida escolar, muitas aprendizagens importantes acontecem e podem refletir para o sujeito adulto de forma positiva ou negativa, a depender de referenciais construídos e de suas experiências vivenciadas. Nas memórias aqui relatadas recordamos que as aulas eram sempre da mesma forma, não havia leitura de histórias realizada pela professora e nem pelos alunos, somente da prática de leitura em pequenos textos de uma cartilha.

Descreveremos também as primeiras experiencias em sala de aula, como ajudante de professores, estagiária e docente formada. Os trabalhos realizados como ajudante tiveram significados positivos, os estágios escolares realizados na formação do magistério proporcionaram conhecimentos fundamentais e na formação acadêmica.

Em um terceiro momento apresentaremos as reflexões das práticas na Educação Infantil, com relato do trabalho desenvolvido de forma lúdica e significativa dentro da realidade dos alunos. E ao analisar as práticas citamos a elaboração de um projeto de leitura com alunos da pré-escola, percebendo então que a leitura de história é muito importante e contribuiu com novas práticas no sentido de despertar o interesse e aprendizagem das crianças sobre o mundo letrado. 
Desta forma, este texto, escrito a quatro mãos, mas relatando a experiência de uma das autoras, será, a partir do próximo item, escrito em primeira pessoa do singular, já que a experiência da práxis relatada é parte da memória da primeira autora deste texto.

\section{Primeiros contatos nas instituições escolares}

No início de minha escolarização ingressei diretamente no primeiro ano do Ensino Fundamental com seis anos e meio de idade. A vontade de estudar era grande, mas algumas coisas foram podadas pela professora que atuava na escolinha de interior. Nos três primeiros anos de vida escolar recebi aulas que eram do mesmo jeito, chegava e começava a copiar do quadro, escrever na cartilha e fazer leituras para a professora. Segundo Corsino, "o letramento é um processo que tem início nas primeiras interações das crianças com a cultura letrada e tende a se estender ao longo da vida[...]" (CORSINO, 2011, p. 247). O início com a cultura letrada precisa ser de forma positiva, para não criar bloqueios e dificuldades no futuro.

As primeiras experiências com a sala de aula começaram na época em que estava cursando a sexta série do Ensino Fundamental. Era uma escola de interior onde no período matutino estudava e no vespertino ficava na escola para cuidar do meu irmão que cursava a pré-escola. Foi nesta época que comecei a dar aulas e a ajudar à professora da pré-escola em suas atividades e outras turmas principalmente a primeira e quarta série.

Hoje penso que esta experiência com as crianças logo cedo fez com que gostasse de ministrar aulas, pois em casa brincava na maioria das vezes de dar aula para meu irmão e uma prima. Estas brincadeiras de faz de conta despertam a imaginação e a criação, desse modo a criança passa a adquirir experiências significativas que auxiliam em decisões e atitudes futuras, à vista disto recordo-me da colaboração das autoras Brandão e Souza quando apontam que:

[...] as brincadeiras de ler também podem ser incentivadas pelos profissionais de Educação Infantil por meio de construção de um espaço na sala reservado para a leitura e o manuseio de livros, o "cantinho de leitura". Nesse espaço, devem estar presentes livros de literatura infantil (de papel, de tecido, de plástico) e outros suportes de escrita, como gibis e jornais, além de colchonetes e almofadas, que podem criar um ambiente aconchegante e agradável para a leitura. Na "hora da leitura", as crianças podem ser incentivadas a "brincar de ler em voz alta" histórias que tenham sido lidas pela professora, fazendo de conta que estão "lendo de verdade", ou mesmo brincar de ler histórias que ainda não foram lidas, apoiando-se nas ilustrações (BRANDÃO; SOUZA, 2011, p.48). 
Os momentos de leitura e faz de conta com as crianças pequenas devem ser criativos, o educador precisa utilizar diferentes práticas e recursos para atrair a atenção dos alunos e incentivá-los a participar de acontecimentos diários com atividades diversificadas que favorecem novos pensamentos e conhecimentos.

$\mathrm{Na}$ infância com meus pais recordo apenas de duas historinhas que minha mãe contou, mas em nenhum momento ouvi a leitura de histórias infantis. Na escola as professoras não tinham o hábito de ler para os alunos, mas sim cobrar deles a leitura, pois o interesse era ensinar a ler. Na oitava série lembro muito bem de uma professora de arte que resolveu ler uma história para toda a turma, esperava com muita expectativa para saber o que iria acontecer a imaginação fluía ao ouvir a leitura. Sobre este aspecto vale lembrar a escrita de Oliveira.

Convivendo com leitores e criadores de textos, a criança busca compreender o sentido das ações de leitura/escrita deles. Muitas práticas educativas de adultos alfabetizados incluem a escrita como objeto intermediário, como ocorre com a contagem de histórias (OLIVEIRA, 2011, p. 233).

A importância de estar em contato com a leitura faz compreender muitas situações de leitura e escrita, neste caso com a contagem de histórias as crianças começam a entender o sentido da leitura e desde pequenos começam a adquirir o hábito de ler e escrever com mais facilidade, pois está presente em suas vidas numa forma natural.

Com o ingresso no magistério comecei a ter novas convivências com sala de aula. No primeiro ano de magistério vimos muita teoria. Já no segundo ano o gostinho pela profissão começou a crescer. Neste ano tínhamos como meta substituir professoras de outras escolas, com a carga horária cinquenta horas de experiências extraclasses. No terceiro ano o ensino era voltado para o estágio supervisionado no período de dois bimestres, que aconteceria no ano seguinte. Com a conclusão do ensino médio e técnico, aconteceu uma nova experiência na docência bem diferente das anteriores, onde foi trabalhar com jovens e adultos durante seis meses.

No primeiro ano do curso de graduação em Pedagogia as aulas eram voltadas para as teorias, no segundo ano começaram a acontecer estágios nas instituições escolares. Para finalizar o curso no terceiro ano, outros estágios aconteceram, juntamente com a escolha de um projeto para aplicar em sala de aula e nesta época escolhi como tema a importância de contar histórias na Educação Infantil. Nesses três anos de faculdade tive um bom aproveitamento, obtive novos conhecimentos e as experiências foram adquiridas no dia a dia nas turmas de préescola. A cada ano sempre estava renovando, aprendendo com os alunos e com os erros e acertos, que fazem refletir e melhorar a atuação com as crianças. 


\section{Análise vivenciada na educação infantil}

Ao iniciar a prática docente sempre tive um sonho, ministrar aulas na préescola, mas o início foi bem diferente comecei com a Educação de Jovens e Adultos e depois com o Ensino Fundamental. Na Educação Infantil iniciei no ano de 2006. As aulas na maioria das vezes eram lúdicas, mas havia uma preocupação por parte da instituição em que era preciso ensinar as crianças a ler e escrever. O que era diferente do que as formações de graduação ensinam para os educadores, sendo que na Educação Infantil os alunos estão presentes para socializar-se, brincar, desenhar, cantar, dançar, ouvir histórias, pintar, entre outros, ampliando conhecimentos. Para completar esta ideia ou pensamento, encontrei no artigo 29 da Lei Diretrizes e Bases da Educação - LDB 9394,

A Educação Infantil, primeira etapa da educação básica, tem como finalidade o desenvolvimento integral da criança até cinco anos de idade, em seus aspectos físico, psicológico, intelectual e social, completando a ação da família e da comunidade (BRASIL, 1996).

$\mathrm{Na}$ Educação Infantil o educador precisa buscar maneiras que ajudam a desenvolver as crianças em várias aprendizagens, com a participação da família que convive. Esta etapa da Educação Básica é o início do desenvolvimento integral da criança, nos aspectos físicos, psicológicos, intelectuais e sociais que refletem resultados na vida adulta.

As aulas da pré-escola seguiam o plano anual com uma grade de conteúdos a serem trabalhados por bimestre, sobrava pouco tempo para aulas lúdicas e com brincadeiras, quando aconteciam todos tinham um horário programado para as realizações.

Conforme consta as Diretrizes Curriculares Nacionais da Educação Infantil:

Construindo novas formas de sociabilidade e de subjetividade comprometidas com a ludicidade, a democracia, a sustentabilidade do planeta e com o rompimento de relações de dominação etária, socioeconômica, étnico-racial, de gênero, regional, linguístico e religioso. (BRASIL, 2010, p. 17).

Os educadores da Educação Infantil necessitam estar comprometidos em elaborar aulas mais lúdicas, para satisfazer as necessidades dos alunos em suas aprendizagens. Promover também atitudes de democracia, oportunizar aulas diferenciadas, porém, dentro de um contexto da sua realidade.

Nos anos seguintes a atuação foi com turmas de maternal durante três anos, a cada ano era um novo desafio. Nas aulas utilizava as historinhas, músicas, desenhos impressos para colorir, tarefas de escrita, alguns até difíceis para aquelas crianças, mas como ainda a preocupação da escola era em ensinar a escrita no papel, sempre planejava algo para ser aplicado. Neste tempo realizava atividades 
diversificadas com os alunos, criando coisas novas, como: roupas de cozinheiros, desenvolvimento de receitas, apresentações com músicas, dramatizações, imitações, muitas rodas de conversa, contava histórias toda semana. Quando escolhia um tema, desenvolvia a semana toda, para poder dar sentido e continuidade do assunto. Outras práticas realizadas na creche foram especiais, chegando a levar para a sala: uma galinha, pintinhos, terra para plantio de sementes, fantoches, livros e outros. Refletindo sobre esta variedade de situações de aprendizagens, me remeto a Oliveira, que faz o seguinte apontamento:

A fim de explorar o papel constitutivo da linguagem no desenvolvimento das crianças, necessita-se trabalhar com elas linguagens verbais, musicais, dramáticas e plásticas, entre outras, e dar-lhes oportunidade de imergir no mundo da cultura escrita pelo contato com os livros [...] (OLIVEIRA, 2011, p. 234).

Para colaborar com o desenvolvimento dos alunos realizava muitas coisas, como: apresentação de quadrilha, piquenique fora do ambiente escolar, gincana, mercadinho, passeio de ônibus, visita ao cinema, confecção de roupas para brincadeiras e apresentações, confecção de um cantinho que representava uma casa com móveis de uma cozinha, o cantinho da leitura que sempre foi simples e por isso pouco atrativo, somente com: uma mesa, toalha, alguns bichinhos, uma caixa com livros de papel. As histórias são tão importantes para as aprendizagens dos alunos e ao fazer esta análise das práticas, dá para perceber que é preciso melhorar o cantinho da leitura.

Ao falar das histórias, onde utilizava mais contar do que ler para meus alunos recordo-me das leituras dos textos de Bresciane:

\begin{abstract}
Ao ler uma história, por sua vez, utilizamos que estão escritas. Embora seja possível interpretar de formas diferentes, modificar a entonação, a altura e o timbre de voz, na leitura do texto é sempre o mesmo, independentemente do leitor. Traz consigo marcas específicas da língua escrita e que não utilizamos cotidianamente ao falar (BRESCIANE, 2006, p. 13).
\end{abstract}

Enfim, esta análise reflexiva sobre as práticas, fez com que percebesse o quanto minhas aulas vêm melhorando com as experiências que adquiro no decorrer do tempo, é somente com a prática que posso perceber pontos positivos e negativos para mudar e aperfeiçoar minhas ações.

\title{
Práticas de leitura na educação infantil
}

Ao analisar minha prática, decidi realizar um projeto sobre a importância das histórias na Educação Infantil, um projeto que tivesse por objetivo ler em voz alta para as crianças de uma turma da Educação Infantil. Verificando em minhas práticas 
percebi que seria positiva esta experiência, pois utilizava muito contar histórias achando que era a melhor forma dos alunos entenderem.

Ao pensar na prática de leitura de histórias para as crianças, segundo Corsino:

\begin{abstract}
A educação infantil é um momento importante na formação do leitor. É uma esfera social em que muitos textos circulam e na qual as crianças podem participar de diferentes eventos e práticas de letramento. A formação do leitor se inicia nas suas primeiras leituras de mundo, nos significados e sentidos produzidos com base no que vê, ouve, percebe, sente, imagina do mundo ao redor, na participação ativa das crianças em situações diversas de interação verbal, nas práticas de ouvir histórias narradas oralmente ou da leitura de textos escritos, na elaboração de significados baseados nos textos ouvidos, na descoberta de que as marcas impressas produzem linguagem (CORSINO, 2011, p. 256).
\end{abstract}

As intervenções com os alunos foram satisfatórias, os mesmos receberam com curiosidade e entusiasmo. Iniciamos com a apresentação de seus nomes e idade, logo comecei a falar do mundo letrado, relatando que tudo em nossa volta possui letras e números que nos ajudam a identificar e comunicar uns com os outros; assim como nas historinhas não é diferente, alguém escreveu utilizando letras e com elas está contando uma história e para saber precisamos ler o que está escrito para entender e conhecer aquele livro.

As atitudes de questionar sobre a necessidade de aprender a ler e entender as diversas informações que nos cercam, faz lembrar os apontamentos de Cardoso:

[...] alfabetizar é também entrar em contato com os diferentes gêneros textuais, compreendendo suas funções e seus usos. Isso significa, por exemplo, que irá desde cedo, por meio da ajuda de um adulto, ouvir a leitura de contos e perceber que pode ler por prazer e ter hábito de leitura (CARDOSO, 2012, p. 34).

O contato com o letramento pode ser através de leituras em diferentes gêneros, desde que um adulto introduza seus conhecimentos, para as crianças terem a oportunidade de compreender em importância de saber ler e sua função. $O$ contato com estas leituras pode ser realizado já no início da vida de uma criança, pois desde cedo podem adquirir hábitos de ouvir leituras e iniciar as próprias leituras mesmo antes de saber ler convencionalmente.

Em outro momento falamos sobre combinados para seguir enquanto ouvia a leitura das histórias. Os combinados neste encontro ficaram escritos em um cartaz e para reforçar fiz a leitura, estes eram: ouvir atentamente, ficar em silêncio, não conversar com os colegas, comentar sobre a história somente no final, não sair para beber água e ir ao banheiro.

Os alunos foram convidados a sentar no chão aleatoriamente para ouvir a leitura da história. Neste espaço comecei a ler o título do livro, o autor e ilustrador, comentei que em todas as histórias tem o nome de quem escreveu e ilustrou. $O$ livro 
lido era: "O Rei Bigodeira e sua banheira", autor Audrey Wood. Quando a leitura começou os olhinhos estavam brilhando para o que iriam ouvir, expliquei que neste dia era para ouvir primeiro e ir imaginando a história e que depois iriam ver os desenhos e as escritas.

Todos ficaram ouvindo, com a exceção de um menino que tentava espiar os desenhos. Durante a leitura parecia que os alunos não estavam entendendo, logo um aluno começou a repetir uma frase do livro: "Socorro, socorro, o rei não sai da banheira". Então, fui percebendo que estavam sim acompanhando a história. Esta relação ao ler um livro para as crianças, me ajudou a refletir sobre questões que não estavam claras para mim até então, e assim pude retomar o que diz Reyes:

Os relatos contados pelas vozes adultas permitem que as crianças entrem em contato com uma língua diferente da fala do imediatismo, e essa experiência acaba sendo fundamental tanto para nutrir o pensamento e dotá-lo de "estruturas invisíveis" que dão coesão à sua própria narrativa (REYES, 2010, p. 67).

A maneira como o professor lê o livro, e esta diferente linguagem que é pronunciada na leitura, faz com que a criança observe e ampliem seu vocabulário, conforme seus pensamentos. Quando o educador realiza a leitura pode fazer diferentes vozes representando os personagens que estão presentes na história, sendo uma forma de poder diferenciar as falas, tornar a leitura atrativa e prender a atenção dos alunos.

Quando realizava a leitura de um livro parecia que estava preenchendo um espaço da aula que sobrou e ajudaria naquele momento. Com isso os alunos tiveram mais o costume de ouvir histórias contadas, e na maioria das vezes visualizavam acessórios, que enfeitavam a contagem das histórias, como: chapéus, óculos, gravata, colete, pintura no rosto, entre outros conforme planejamento.

O ler ou contar histórias para as crianças, em momentos de rodas de conversas, faz despertar várias curiosidades nestes ouvintes e futuros leitores. $O$ entrosamento entre professor e aluno passa a ser o mesmo. Assim nos reportamos novamente às autoras Brandão e Souza:

A participação da criança em rodas de história oportuniza a formação de uma comunidade de ouvintes que compartilha histórias de forma sincrônica no sentido temporal e espacial. Professora e crianças passam a dispor de um mesmo repertório de narrativas. Elas não apenas conhecem as mesmas histórias, mas podem manifestar gostos parecidos, ter personagens favoritos, paixões pelos mesmos autores ou histórias (BRANDÃO; SOUZA, 2011, p.37).

O professor pode planejar aulas com hora da leitura, momentos agradáveis e com trocas de conhecimentos que despertam a imaginação, a imitação, a confiança em pronunciar ideias, desejos, entendimentos, compartilhando do mesmo assunto. 
Ao terminar a leitura três alunas gravaram pontos significantes da história, demonstrando o que havia entendido no decorrer da leitura. Depois com a visualização das ilustrações, os alunos ficaram maravilhados com os desenhos e começaram a conhecer mais sobre a história e assim também fui contando e perguntando o que eles se lembravam da leitura, comparando com a gravura representada na página. Em se tratando da importância de mediar uma conversa sobre a leitura, Brandão e Souza enfatizam que:

Entendemos que na Educação Infantil é preciso que a professora, enquanto leitora mais experiente e mediadora entre as crianças e os textos, tenha a preocupação de não apenas escolher boas histórias, mas também de encaminhar uma boa conversa em torno desses textos (BRANDÃO; SOUZA 2011, p. 42).

Para obter sucesso nas aulas de leitura o educador precisa ter sempre em mãos um planejamento, saber quais as práticas que utilizará e o encaminhamento da aula no momento de leitura. As rodas de conversa, após a leitura, fazem com que as crianças tenham a oportunidade de expor suas ideias e entendimentos da leitura que acabaram de ouvir.

Em outro momento as crianças já perguntaram qual história iriam ouvir. Logo fomos para o pátio da escola, relembramos os combinados para ouvir as histórias. Neste dia foi realizada a leitura da história: "Essa não é minha cauda" de Carla Baredes e lleana Lotersztain. A leitura foi da seguinte forma: quando lia mostrava as ilustrações para os alunos irem associando o que ouviram com o que estavam vendo. A história era um pouco longa para esta idade, percebi que muitos estavam curiosos para saber logo o final. Estas práticas devem fazer parte das rotinas de sala de aula, as leituras não devem passar despercebidas.

Em outra atividade as crianças ficaram felizes em saber que neste dia mais uma leitura aconteceria. A leitura foi da história: "A escolinha do mar" de Ruth Rocha, primeiramente eles viram a capa e a leitura começou a acontecer. O método utilizado foi ler a história com o livro aberto na página da leitura e os alunos já podiam ir visualizando as ilustrações ao mesmo tempo e ao terminar a história aconteceriam os comentários.

Em outro encontro cheguei à sala de aula com uma fantasia para chamar a atenção e descontrair os alunos. Os alunos foram convidados para sentarem no chão e mostrei a primeira história que havia contado. Muitos responderam falando: "Há esta história você já leu!". Iniciei falando que gostaria de ver quem se lembrava da história e sabia dos acontecimentos. Mostrei a capa do livro e uns falaram: "O Rei na banheira", realizei a leitura da seguinte maneira: leitura da história e após mostrava as ilustrações para comentários e discussões. Estas atividades me fizeram concluir que educador possui um papel fundamental e pode assumir o compromisso de estar sempre inovando suas ideias com aulas que desenvolvam as crianças de maneira integral. 


\section{Considerações finais}

Ao encerrar a escrita deste texto, onde relato um pouco da minha história, inicialmente como aluna e depois como professora, percebo que muitos acontecimentos importantes da minha vida foram vivenciados em uma instituição escolar. Acontecimentos estes, que hoje ao retomar, percebo o quanto influenciaram minha escolha profissional e consequentemente as minhas práticas como docente.

Ao retomar minhas memórias, foi possível ainda, refletir sobre os acontecimentos positivos e negativos e como estes marcaram minha trajetória. Ao rememorar as lembranças sobre a postura de alguns professores, me vejo em condições de avaliar como estes docentes, com seus métodos de ensino marcam a trajetória dos alunos. Por isso, agora mais do que antes, percebo como é importante refletir sobre minhas práticas e sobre minhas atitudes diante das crianças com as quais convivo e tenho a responsabilidade de cuidar e educar.

Ao avaliar minha trajetória, o período da inserção na docência até chegar aos dias de hoje, pude além de realizar uma reflexão, pensar ainda nas mudanças que ainda preciso assumir diante do meu fazer pedagógico. Assim sendo, a escolha pelo tema: "práticas de leitura na educação infantil" foi significativa e muito contribuiu para que eu pudesse aprender a observar as crianças quando estão ouvindo a leitura de histórias.

Durante a realização desta proposta, percebi ainda que quando as crianças estão ouvindo a leitura conseguem captar diferentes e importantes trechos num mesmo contexto. A aplicação de práticas como esta pode tornar as aulas mais agradáveis e quem sabe despertar entusiasmo nas crianças bem como o desejo de participar de forma ativa desses momentos. Este projeto de práticas de leitura na Educação Infantil, me fez rever a forma como antes apresentava os livros infantis para as crianças e como poderia modificar atitudes e pensamentos já construídos sobre a contação de histórias.

Os estudos realizados durante o curso de Especialização em Docência na Educação Infantil foram significantes para poder rever e pensar sobre todos os acontecimentos da minha vida, mudando pensamentos em relação a conhecimentos já existentes e fazendo refletir sobre minhas ações enquanto educadora, para continuar cuidando, educando, ensinando e aprendendo ainda mais com as crianças. Sendo assim, o educador tem o papel fundamental para auxiliar nas aprendizagens de maneira a colaborar com a formação individual dos alunos. 


\section{Referências}

BRANDÃO, R. A.; ROSA, C. E. C. S. Entrando na roda as histórias na educação infantil. In: BRANDÃO, R. A.; ROSA, C. E. C. S.(Orgs.). Ler e escrever na Educação Infantil: discutindo práticas pedagógicas. Belo Horizonte: Autêntica Editora, 2011. cap. 2 p. $33-51$.

BRASIL. Lei de Diretrizes e Bases da Educação Nacional. Lei 9394/96. Brasília, 1996.

. Diretrizes Curriculares Nacionais para a Educação Infantil. CNB/CEB Parecer n.22/98 e Resolução CEB n.1/99. Brasília, DF, 2010.

BRESCIANE, A.L.A. Reflexões do Formador. Revista Avisalá. Junho de 2006. p. 12- 13.

CARDOSO, B. P. A. Práticas de Linguagem Oral e Escrita na Educação Infantil. São Paulo: Editora Anzol, 2012.

CORSINO, P. Professoras de Educação Infantil e suas visões de letramento: tensões da prática. In: ROCHA, E.A.C.; KRAMER, S. (Orgs.). Educação Infantil: Enfoques em diálogo. Campinas: Editora Papirus, 2011. p. 241-257.

OLIVEIRA, Z. M. R. Educação Infantil: Fundamentos e métodos. 7.ed.- São Paulo: Cortez Editora, 2011.

REYES, Y. A casa imaginária: leitura e literatura na primeira infância. São Paulo: Global Editora, 2010. 


\title{
Projetos didáticos na educação infantil: possibilidades concretas de trabalho interdisciplinar
}

\author{
Aline Zorzi Schultheis de Freitas \\ Juracy Machado Pacífico
}

\section{Introdução}

A educação infantil, primeira etapa da educação básica e obrigatória a partir dos quatro anos de idade, deve promover experiências que valorizem a criança e desenvolva habilidades e hábitos necessários para vida cidadã a fim de contribuir, como ressaltado no art. 29 do Referencial Curricular Nacional para a Educação Infantil, com "o desenvolvimento integral da criança de até 5 (cinco) anos, em seus aspectos físico, psicológico, intelectual e social, complementando a ação da família e da comunidade." (BRASIL, 1998,). Para que as práticas pedagógicas dessa etapa sejam significativas os professores envolvidos precisam refletir sobre aspectos relevantes característicos da infância e da educação infantil.

O presente trabalho pretende discutir algumas dessas características e demonstrar com a prática por meio do projeto "Aprendendo a se alimentar na educação infantil: pressuposto para uma qualidade de vida" contribuiu para o desenvolvimento integral dos alunos envolvidos.

A organização do tempo e dos conteúdos nas escolas brasileiras evidenciam ainda um modelo de ensino tradicional, no qual os conteúdos são tratados de forma fragmentadas e descontextualizada, porém, o trabalho com projeto pode contribuir para a interdisciplinaridade e contextualização do ensino. Os projetos precisam abranger temáticas de interesse dos alunos, preferencialmente serem propostos a partir de uma problemática real.

O projeto "Aprendendo a se alimentar na educação infantil: pressuposto para uma qualidade de vida" foi construído a partir da problemática apresentada durante a rotina das crianças na escola. Os hábitos alimentares da maioria das crianças não contemplavam o consumo de frutas, legumes e verduras. As crianças recusavam-se 
a comê-las durante as refeições oferecidas na escola. No geral, os lanches trazidos de casa incluíam sucos artificiais, bolachas recheadas e salgadinhos.

A temática "alimentação saudável" foi apresentada durante o projeto de forma interdisciplinar abrangendo dois âmbitos de experiências propostos para a Educação Infantil no Referencial Curricular Nacional para a Educação Infantil (BRASIL, 1998) que são: Identidade e Autonomia e Conhecimento de Mundo. Neste último foram trabalhados os eixos movimento, artes visuais, música, linguagem oral e escrita, natureza e sociedade e matemática.

$\mathrm{Na}$ educação Infantil o educar e o cuidar caminham juntos, por isso os professores dessa etapa precisam estar atentos a oportunidades para manter essa relação.

\section{A infância e a educação infantil}

De acordo com a Lei de Diretrizes Bases da Educação (Lei N 9394/96), seu Art. 30, inciso I e II, a educação infantil será oferecida em "creches, ou entidades equivalentes, para crianças de até três anos de idade; e pré-escolas, para as crianças de 4 (quatro) a 5 (cinco) anos de idade" (BRASIL, 1996). Conforme, já citado, o objetivo dessa etapa da educação tem como principal finalidade o desenvolvimento integral das crianças.

Nesta etapa da educação básica os educadores têm a oportunidade de proporcionar às crianças atividades que irão desenvolver hábitos necessários para toda a vida. Por isso, podemos afirmar que os primeiros conteúdos da educação infantil estão intimamente ligados à vida cotidiana. São exemplos de conteúdos dessa faixa etária: alimentação, cuidados com o corpo, brincar em um grupo, autonomia, movimentar-se, etc. Segundo Barbosa (2009, p. 4) "Os conteúdos da educação infantil têm como referência a aprendizagem das práticas sociais de uma cultura, isto é, as ações que uma cultura propicia para inserir os novos na sua tradição cultural".

Para Vygotsky (2000), a criança se desenvolve a partir da influência da cultura e do meio em que está inserida. Partindo deste pressuposto, um dos locais onde ocorre esse desenvolvimento é a escola de educação infantil, pois lá as crianças estarão em contato como outras crianças e adultos. Assim, deve se refletir sobre situações pedagógicas que podem contribuir para essas interações.

Ao tratarmos do currículo da educação infantil é tendencioso colocarmos em pauta apenas a discussão de conteúdos que serão ministrados, visto que o currículo deve abranger muito mais do que somente os conteúdos. O currículo da educação 
infantil deve partir das experiências das crianças. Para que ocorra o desenvolvimento integral da criança o currículo precisa favorecer os aspectos físicos, sociais, afetivos e cognitivos. Pensar no tempo e no espaço nessa faixa etária torna-se um pressuposto importante para que se alcançar esses objetivos.

O espaço não é apenas um pano de fundo da proposta na educação infantil. Ele ocupa um papel decisivo na educação das crianças. O espaço pode desafiar e contribuir para a busca de novos conhecimentos, deve estar voltado para as interações da criança com o ambiente e o ser humano, a ludicidade e o cuidado. $O$ ambiente escolar deve ser organizado e planejado para as crianças que serão atendidas. Os cantinhos temáticos que podem ser organizados favorecem 0 desenvolvimento e as relações sociais.

O tempo e o espaço precisam ser organizados de acordo com as necessidades da faixa etária. O espaço para crianças de 0 a 1 ano, por exemplo, deve ser voltado para o cuidar e educar. Cantinhos para a troca de fraldas, tomar banho, dormir, ter liberdade para escolher os brinquedos que a criança deseja manipular são apropriados para atender essa faixa etária. Os cuidados com a criança nessa fase, precisam de mais atenção, assim, o tempo é organizado de acordo com as necessidades individuais da criança.

O espaço para crianças de 1 a 6 anos é organizado de formar a possibilitar a criança ter contanto com a cultura infantil, ou seja, deve favorecer os jogos, as brincadeiras, as músicas e histórias adequados à faixa etária. Esse espaço deve a favorecer a construção do conhecimento e o desenvolvimento de habilidades da criança, como a autonomia e da identidade.

O tempo também deve ser organizado de modo que favoreça a aprendizagem e o desenvolvimento das habilidades. Segundo o Referencial Curricular para a educação infantil,

A rotina representa também como será organizado o tempo didático, ou seja, o tempo educativo realizado com as crianças. A rotina deve envolver os cuidados, as brincadeiras e as situações de aprendizagem orientadas (BRASIL, 1998, p. 54).

Desta forma, o tempo organiza o espaço internamente. Diante dessa proposta curricular o professor precisa observar atentamente as mediações que serão necessárias realizar. Os professores devem estimular as crianças diante suas novas experiências e descobertas, ações como escutar com atenção, dialogar e as apoiar são ações fundamentais para a estimulação dessa busca por novas experiências e conhecimentos.

Uma das principais atividades da criança é o brincar. Este, além de ser prazeroso para elas é uma oportunidade para o desenvolvimento. A brincadeira oportuniza a criança a se expressar e adquirir diversas habilidades, além de explorar o mundo que a rodeia e incentivar a imaginação. A criança não nasce sabendo a 
brincar, pelo contrário a criança precisa aprender a brincar. As brincadeiras são aprendidas dentro de um contexto sócio cultural.

Durante a brincadeira diversos conhecimentos podem ser adquiridos. A socialização, por exemplo, pode ser trabalhada nesses momentos. A criança ao brincar com outros indivíduos, além de interagir, aprende a dividir o brinquedo, aprende a comunicar seus desejos, como quer usar aquele brinquedo, dependendo da brincadeira a criança por si só distribui papeis diferentes para os envolvidos na brincadeira. São nesses momentos que as crianças trazem à tona como veem a realidade em que estão inseridas, pois em suas brincadeiras elas imitam o mundo real.

Ao brincar a criança explora o mundo do faz de conta. A imaginação faz com que um brinquedo tome diversas formas e funções. Esse imaginar contribui para o desenvolvimento do pensamento e da linguagem oral.

Os professores da educação infantil precisam se preocupar em dar formas lúdicas aos conteúdos. É necessário criar jogos e brincadeiras que ensinem as crianças o conhecimento que se quer construir. $O$ jogo também como ferramenta de apoio da prática pedagógica estimula ao raciocínio de uma forma lúdica e prazerosa. Kishimoto (1994, p. 196) ressalta a importância do jogo quando escreve:

Considerar que o jogo tem um sentido dentro de um contexto significa a emissão de uma hipótese, a aplicação de uma experiência ou de uma categoria fornecida pela sociedade, veiculada pela língua enquanto instrumento de cultura dessa sociedade. Toda denominação pressupões um quadro sociocultural transmitido pela linguagem e aplicação do real.

A partir destes referencias podemos concluir que as brincadeiras, os jogos e os brinquedos levam a criança a pensar, descobrir, imaginar, criar soluções para problemas que surgem durantes as atividades, estimula a linguagem oral e contribui para o desenvolvimento psicomotor. Na educação infantil é importante utilizar as brincadeiras, os jogos e os brinquedos como meios pedagógicos, no quais o professor poderá fazer as intervenções necessárias para a construção do conhecimento. A educação pelo lúdico leva a uma aprendizagem espontânea, a um maior interesse e ao aumento da autoconfiança.

Dentro deste contexto o professor pode também explorar a arte e a linguagem. A arte tem capacidade de trabalhar todas as habilidades cognitivas. Podemos explorar os diversos conteúdos da arte em todos os níveis de ensino, mas em especial na Educação Infantil devemos fazer isso como forma de exploração do mundo e expressão, trazendo ganhos significativos ao desenvolvimento infantil.

Experiências como ouvir músicas, dançar, modelar, desenhar, ouvir contos e histórias devem ser práticas presentes diariamente nas salas de educação infantil, experiências como estas estimulam a imaginação, transformando a maneira como 
as crianças percebem o mundo e ao mesmo tempo as colocam em contanto com a história da cultura em que está inserida.

A imaginação, por sua vez, é um pressuposto essencial para o desenvolvimento de novas funções psicológicas. A imaginação desenvolve a memória imediata que por vez contribui para o desenvolvimento da memória mediada. Por meio das lembranças e da vida real a criança consegue projetar a atividade futuras, dando assim significado ao seu pensamento.

A linguagem é outro aspecto importante a ser explorado na Educação Infantil. Trabalhar com contos e histórias na educação infantil contribui para o desenvolvimento social, cognitivo e afetivo das crianças. Ao ouvir uma história as crianças passam a conhecer novos personagens e lugares, além envolver-se emocionalmente, pois o ser humano é dotado da capacidade de imaginar, ou seja, ao ouvir a história a criança é capaz de se colocar nela.

Em diversos momentos da história contos infantis foram usados por autores famosos para retratar a realidade em que estavam inseridos. Assim o professor ao contar uma história pode estabelecer relações com a realidade das crianças, podendo enriquecer o conhecimento de mundo delas.

Além de todos esses fatores já citados a literatura infantil contribui para o desenvolvimento da criatividade. Santos e Oliveira (2012, p. 8) afirmam isso ao escrever:

\begin{abstract}
Desde o século passado percebe-se a importância que a Literatura Infantil ocupa na vida de muitas pessoas, principalmente na vida das crianças, as quais são as que ficam mais encantadas com esse mundo deslumbrado do faz de conta. E não precisa ser crianças já alfabetizadas. Pelo contrário, os menores, que ainda não conhecem o universo da língua escrita e nem da leitura por palavras são as que mais sabem aproveitar as fantasias e as que mais viajam pelo mundo da imaginação.
\end{abstract}

Os professores da educação infantil podem ainda usar a literatura infantil com o objetivo de desenvolver a linguagem oral, o lúdico e despertar nas crianças o gosto pela leitura. Mas para atingir todos estes objetivos são importantes que seja uma "[...] literatura enriquecedora, criativa, fantástica, estimuladora e de grande prazer" para as crianças e todos os que ouvem (SANTOS; OLIVEIRA, 2012, p. 12).

Quando utilizamos a literatura infantil na educação infantil estamos proporcionando aos nossos alunos uma aprendizagem por meio do brincar, no qual a criança sente desejo e prazer para aprender, isso acontece porque "as brincadeiras, histórias, dramatizações, músicas proporcionam um mundo mágico para as crianças" (SALMERON; ARAÚJO; SANTANA, 2011, p. 10).

A partir dessas considerações, foi construído o projeto "Aprendendo a se alimentar na educação infantil: pressuposto para uma qualidade de vida". O projeto foi proposto a partir de uma problemática observada no espaço escolar e envolveu 
jogos, brincadeiras e outras atividades abordavam de forma interdisciplinar a temática "alimentação saudável".

\section{A experiência didática com as crianças de 03 anos}

O projeto "Aprendendo a se alimentar na educação infantil: pressuposto para uma qualidade de vida" foi desenvolvido com crianças de três anos no maternal III de uma escola municipal de Manaus, Amazonas. As atividades foram organizadas em etapas e foram desenvolvidas durante cinco dias, em diversos ambientes da escola, entre eles a sala de aula, laboratório de informática, refeitório e quadra esportiva.

O objetivo da primeira etapa era diagnosticar e registrar a alimentação individual dos alunos, bem como utilizar a música como fonte para ampliar os conhecimentos em relação à diversidade alimentar. A roda de conversa serviu como instrumento de diagnostico, com questionamentos como: O que vocês mais gostam de comer? Quem gosta de comer verduras, legumes e frutas? Quem come esses alimentos todos os dias? Durante a atividade foi observado que diversas crianças expressaram seu gosto por comer doces, salgadinhos e frituras, mas algumas falaram que gostam de comer frutas e verduras, porém não comem com frequência.

A segunda atividade envolvia música e movimento e foi realizada na quadra. A música temática "Comer, Comer" foi a base da atividade. "[...] A linguagem musical é excelente meio para o desenvolvimento da expressão, do equilíbrio, da autoestima e autoconhecimento, além de poderoso meio de integração social" (BRASIL, 1998, p. 49). Após ouvirem a música as crianças puderam se expressar por meio do movimento corporal.

O movimento para a criança pequena significa muito mais do que mexer partes do corpo ou deslocar-se no espaço. A criança se expressa e se comunica por meio dos gestos e das mímicas faciais e interage utilizando fortemente o apoio do corpo. A dimensão corporal integra-se ao conjunto da atividade da criança. $O$ ato motor faz-se presente em suas funções expressiva, instrumental ou de sustentação às posturas e aos gestos (BRASIL, 1998, p. 18).

A última atividade dessa etapa teve como objetivo investigar e registrar os alimentos que eram consumidas pelas crianças e suas famílias. Utilizando material impresso, como revistas, jornais e encartes, elas confeccionaram um cartaz com o auxílio da professora. De acordo com Vygostsky (2000) a aprendizagem acontece por meio das interações e o processo de aprendizagem é social e histórico, assim atividades em grupo como esses contribuem para aprendizagem, pois se tratam de momentos de interação com o outro. 
A segunda etapa envolvia a pirâmide alimentar e tinha como objetivo pesquisar junto aos alunos quais são os alimentos saudáveis e como devem ser consumidos. Foi apresentado às crianças a pirâmide alimentar do material do Programa de Ensino Sistematizado de Ciências (PESC). Esse material torna-se viável para educação infantil, pois não se apresenta como um material pronto e acabado e foi elaborado com imãs no quais as crianças podem manusear objetos concretos durante a aprendizagem. Ao brincarem com a pirâmide, foi possível fazer as mediações necessárias a fim de demonstrar como cada parte da pirâmide representa a quantidade de alimentos que se pode comer, por exemplo, os doces no topo da pirâmide representam que devemos comer apenas de vez em quando, enquanto as frutas e verduras podem ser consumidas de três a cinco vezes ao dia.

As atividades interdisciplinares proporcionam tratar de um assunto de forma transversal, assim durante esta atividade foram explorados também as cores, as formas e quantidades presentes na pirâmide alimentar. Foram também explorados os conhecimentos de artes visuais por meio do desenho para desenharam o que haviam acabado de conhecer. A arte pode ser explorada na educação de diversas maneiras, inclusive utilizando materiais recicláveis. Utilizando as embalagens trazidas de casa as crianças, com auxílio da professora, classificaram os alimentos em saudáveis e não saudáveis.

As Artes Visuais estão presentes no cotidiano da vida infantil. Ao rabiscar e desenhar no chão, na areia e nos muros, ao utilizar materiais encontrados ao acaso (gravetos, pedras, carvão), ao pintar os objetos e até mesmo seu próprio corpo, a criança pode utilizar-se das Artes Visuais para expressar experiências sensíveis (BRASIL, 1998, p. 85).

Nessa atividade a arte foi utilizada para registrar as experiências vividas durante o manuseio da pirâmide alimentar. O entusiasmo das crianças demonstra a validade de práticas mediadas pelo lúdico.

A terceira etapa do projeto envolvia atividades lúdicas e multimídias. A partir da observação da pirâmide alimentar menor, construiu-se junto com as crianças uma pirâmide em isopor maior. Cada parte da pirâmide foi construída proporcionalmente com as cores e tamanhos da pirâmide observada no material do PESC. Os alunos manusearam a pirâmide de isopor como quebra cabeça. Utilizando diversos alimentos as crianças puderam colocar nos lugares representados pelas cores da pirâmide a quantidade que podíamos comer dele diariamente.

As tecnologias da comunicação e informação (TIC) precisam também estar presentes nas práticas educacionais, pois ela tem causados diversas mudanças na sociedade contemporânea e precisam estar presentes na educação, conforme aponta Arruda (2009, p.13),

Percebe-se, empiricamente e na literatura estudada, que as transformações tecnológicas vividas pelos sujeitos na contemporaneidade representam não só a introdução de equipamentos e "técnicas" na sociedade, mas, 
principalmente mudanças de ordens sociais, culturais, de trabalho e educacionais. [...].

Essas mudanças não ocorrem indissociadas da escola, assim os educadores precisam buscar meio para articular as TICs ao processo de aprendizagem dos alunos. A prefeitura de Manaus já por algum tempo tem disponibilizado essas tecnologias, porém não se trata apenas de ter essas tecnologias na escola, os professores precisam as utilizá-las como potencializadoras para formação de cidadãos críticos. Para que isso ocorra essas não podem ser deixadas guardadas ou utilizadas apenas como instrumentos, mas precisam ser utilizadas de forma contextualizada.

Nessa etapa do projeto foi utilizada a lousa interativa, disponível no laboratório de informática, com o jogo digital "frutas". O jogo tinha como objetivo explorar o conhecimento quanto às frutas, bem como desenvolver as habilidades de movimento e classificação de objetos.

O jogo, além de proporcionar interações, contribui para o desenvolvimento da identidade e da autonomia. As regras do jogo foram exploradas para o respeito mútuo e o trabalho em equipe, ressaltando a necessidade das relações interpessoais. As crianças durante o jogo demonstram familiaridade com as tecnologias e entusiasmo durante o desenvolvimento da atividade.

A quarta etapa do projeto foi repleta de imaginação e encanto. $O$ teatro de fantoche levou as crianças a viajarem pelo mundo do faz de conta. Os objetivos destas atividades era oportunizar as crianças vivências que envolviam a literatura infantil, destacando valores fundamentais para a vida em sociedade; ampliar o conhecimento de mundo através da apreciação e dramatização de histórias e estimular a imaginação e a fantasia por meio de contos e desenhos. A história dramatizada com fantoche foi "Amanda no país das vitaminas". A história conta sobre uma menina que conversa com as frutas e verduras e essas mostram a importância de serem consumidas diariamente. As atividades que envolvem história, música, e outras atividades orais contribuem para o desenvolvimento da linguagem oral.

[...] A linguagem não é apenas vocabulário, lista de palavras ou sentenças. É por meio do diálogo que a comunicação acontece. São os sujeitos em interações singulares que atribuem sentidos únicos às falas. A linguagem não é homogênea: há variedades de falas, diferenças nos graus de formalidade e nas convenções do que se pode e deve falar em determinadas situações comunicativas. Quanto mais as crianças puderem falar em situações diferentes, como contar o que Ihes aconteceu em casa, contar histórias, dar um recado, explicar um jogo ou pedir uma informação, mais poderão desenvolver suas capacidades comunicativas de maneira significativa (BRASIL, 1998, p. 121).

Baseado nesse conceito exposto no RCNEI, depois da história com fantoches, foi direcionado uma conversa com as crianças sobre a importância de 
consumir regularmente frutas e verduras. Nesse momento as crianças foram convidadas também a contarem a história manuseando os fantoches.

A última etapa do projeto foi uma atividade de culinária realizada no refeitório da escola. As crianças com auxílio da professora preparam uma vitaminada. Durante o preparo foi possível explorar e conhecer as frutas, fazer a contagem, comparações entre elas, observar a cor, tamanho, formato. Atividades práticas contribuem para sensibilização da importância da mudança de alguns hábitos. Diversas vezes foi oferecido vitaminada durante as refeições na escola, mas as crianças se recusavam a tomar, mas isso não aconteceu quando elas participaram do processo de produção da vitaminada. Todos os alunos degustaram da vitaminada preparada por eles.

Os resultados esperados foram alcançados durante o projeto, além de ter sido atividades prazerosas para as crianças, pode-se afirmar que a maioria delas se sensibilizou quanto consumir alimentos saudáveis. Muitas crianças expressaram oralmente que iriam degustar frutas e verduras em casa. Durante a hora do lanche foi observada por parte da equipe educacional que a resistência em comer legumes e verdura na comida foi menor, algumas crianças até mesmo expressaram oralmente: "Professora, estou comendo a verdura." Muitos pais relataram que seus filhos estão comendo frutas e verduras oferecidas em casa.

\section{Considerações finais}

Ao analisarmos a prática pedagógica por meio do projeto apresentado nesse texto, podemos observar a importância de trabalhar os campos de experiências da educação infantil de forma interdisciplinar. As experiências vivenciadas pelas crianças em seus diferentes contextos precisam ser apresentados na escola forma contextualizada para que ocorra uma aprendizagem significativa, tendo como referencias as experiências vividas pelas crianças. Assim, o trabalho com projeto oportuniza a desfragmentação do currículo.

O ato de brincar na educação infantil não acontece apenas como passatempo, mas sim como parte do processo de aprendizagem e desenvolvimento da criança. A brincadeira dentro do contexto educacional potencializa a aprendizagem. Os professores desta etapa educacional, como mediadores, precisavam valorizar e analisar essa atividade como algo essencial da infância e forma de aprendizagem significativa.

Durante as brincadeiras e jogos a criança é estimulada ao desenvolvimento da imaginação e do faz de conta. Ao brincar a criança representa o contexto cultural e social que está inserida. Os professores da educação infantil podem propor 
atividades lúdicas para o desenvolvimento da aprendizagem. Assim, as práticas pedagógicas da educação infantil precisam ser significativas e contextualizadas a fim de contribuir para o desenvolvimento integral das crianças.

\section{Referências}

ARRUDA, Eucidio. Relações entre tecnologias digitais e educação: perspectivas para a compreensão da aprendizagem escolar contemporânea. In: FREITAS, Maria Teresa de Assunção (org). Cibercultura e formação de professores. Belo Horizonte: Autêntica Editora, 2009.

BARBOSA, Maria Carmen Silveira (Consultoria). Projeto de cooperação técnica MEC e UFRGS para construção de orientações curriculares para a educação infantil - pratica cotidianas na educação infantil - bases para a reflexão sobre as orientações curriculares. MEC/Secretaria de Educação Básica - Universidade Federal do Rio Grande do Sul, BRASílIA, 2009. Disponível em: $<$ http://portal.mec.gov.br/dmdocuments/relat seb praticas cotidianas.pdf $>$. Acesso em: 07 abr. 2016.

BRASIL. Lei de Diretrizes e Bases da Educação, lei n 9394/96. Brasília. Disponível em: <www.planalto.gov.br/ccivil 03/leis/L9394.htm>. Acesso em: 07 abr. 2016.

- Ministério da Educação e do Desporto. Secretaria de Educação Fundamental. Referencial curricular nacional para a educação infantil / Ministério da Educação e do Desporto, Secretaria de Educação Fundamental. - Brasília: MEC/SEF, 1998. Volume 2.

KISHIMOTO, T. M. O jogo e a educação infantil. São Paulo: Pioneira, 1994.

MARREGA. Stela Nolla. Jean Piaget e as Fases do Desenvolvimento Infantil. $2014 . \quad$ Disponível em: <http://www.portaleducacao.com.br/psicologia/artigos/55035/jean-piaget-e-as-fasesdo-desenvolvimento-infantil\#ixzz458pqGToR>. Acesso em: 07 abr. 2016.

SALMERON, V. M. C.; ARAÚJO, L. SANTANA; S., P. T. S. O lúdico na educação infantil - aprendendo brincando. In: V Colóquio Internacional "Educação e Contemporaneidade", 2001, São Cristóvão, SE.

SANTOS, Polyana Fernandes Pereira dos; OLIVEIRA, Marco Aurélio Gomes de. A literatura infantil na educação infantil. Revista Científica do ITPAC, Araguaína, v.5, n.2, Pub.5, Abril 2012.

VIGOTSKI, L. S. A construção do pensamento e da linguagem. São Paulo: Martins Fontes, 2000. 


\author{
A formação social implícita nas possibilidades do faz-de-conta \\ Marli Luiz Pereira \\ Adriana L. de O. Rodrigues \\ Josélia Gomes Neves
}

\title{
Introdução
}

São muitas as aplicações das brincadeiras e suas implicações na aquisição dos bons resultados na Educação Infantil. Mas qual a relação do faz-de-conta com a formação da criança? O que se constrói nesses momentos? Como devem ser proporcionados os momentos do faz-de-conta?

Considerando todas as dimensões que constituem a brincadeira, este capítulo tem a perspectiva de perpassar um breve histórico da visão de brincadeira através da história, sua definição e a relação que a mesma tem com a construção da cultura social na reinterpretação do mundo vivida pelas crianças nos momentos de faz-deconta com seus pares.

A abordagem da temática faz-de-conta por meio das brincadeiras foi possível em intervenção pedagógica realizada na EMEI Primeiro Traços, no município de Presidente Médici-RO, em novembro de 2014, como atividade prática do Curso de Especialização em Docência na Educação Infantil, oferecido pela Universidade Federal de Rondônia em Parceria com o Ministério da Educação.

\section{Brincadeira: um breve histórico}

No decorrer da história a brincadeira tem provocado discussões e foi vista sob vários ângulos e com objetivos diferentes. $\mathrm{Na}$ Antiguidade adultos e crianças 
participavam das mesmas brincadeiras em comunidade, estreitando os laços afetivos. Parte da sociedade via a brincadeira como meio de crescimento social, no entanto, a outra parte recriminava por ver nesta uma associação ao prazer e aos vícios, considerados danosos à sociedade (WAJSKOP, 1995).

No período do Renascimento os humanistas atentaram às possibilidades educativas dos jogos e brincadeiras, considerando-a como forma de preservar a moralidade dos "mini adultos", selecionando o que consideravam "mau" ou "bom".

No Romantismo foi vista como expressão da criança e a infância foi entendida como período de desenvolvimento específico e com características próprias, passando daí a ser valorizada no espaço educativo. A partir disso vários pesquisadores desenvolveram propostas pedagógicas com a utilização de brinquedos e jogos como Froebel, Decroly e Montessori (KISHIMOTO, 1990).

No século $X X$, vários pesquisadores também discutiram o tema, entre eles Piaget (1978), afirmando que a partir da brincadeira a criança pode demonstrar seu nível cognitivo e a construção de conhecimentos. Já Vygotsky (1984) a caracteriza como comportamento humano e resultado de influências sociais que a criança recebe ao longo do tempo.

Atualmente, no Brasil, além de outros documentos que garantem o direito de brincar, destaca-se a as Diretrizes Curriculares Nacionais para o Ensino Infantil (DCNEls) (BRASIL, 2009), que em seus objetivos gerais e a função sociopolítica e pedagógica das instituições de ensino infantil, também incluem a ludicidade como importante para a criança nesta fase de sua vida, constituindo compromisso, ao ter da criança, uma visão de sujeito de direitos a serem garantidos. Ainda nesse estudo sobre o documento, Oliveira enfatiza que:

\begin{abstract}
Brincar dá à criança oportunidade para imitar o desconhecido e construir o novo, conforme ela reconstrói o cenário necessário para que sua fantasia se aproxime ou se distancie da realidade vivida, assumindo personagens e transformando objetos pelo uso que deles faz. Nas brincadeiras de faz-deconta se produz um tipo de comunicação rica em matizes e que possibilitam às crianças indagarem sobre o mundo [...] Aprende a coordenar seu comportamento com os de seus parceiros e a desenvolver habilidades variadas construindo sua identidade (OLIVEIRA, 2010, p.13).
\end{abstract}

Desta forma, hoje a brincadeira deve permear as práticas pedagógicas no Ensino Infantil, encontrando em seus defensores a fórmula para o sucesso da criança em suas relações de conflitos de interpretação dos significados do mundo que a rodeia. 


\section{Faz-de-conta: uma brincadeira formadora}

As várias definições de brincadeira buscam sempre lembrar que esta só existe onde predomina a espontaneidade específica da infância quando o poder de criar e recriar a realidade é intenso.

Segundo Bomtempo, (1987), ela é caracterizada como atividade ou ação própria da criança, voluntária, prazerosa, delimitada no tempo e no espaço e constituída de reforçadores positivos intrínsecos, íntimos com a criança. Se a atividade é imposta não se trata então de brincadeira. Ela mostra como a criança interpreta e assimila o mundo, os objetos, a cultura e o afeto das pessoas, sendo um espaço característico da infância.

Ainda complementando o sentido de liberdade e espontaneidade, Fortuna (2012) destaca a brincadeira como um ato livre, espontâneo, porém destaca que a mesma é uma atividade paradoxal, pois, ao mesmo tempo em que, é livre, é também regulamentada. Nela, a criança age conectada à realidade, mas como se estivesse em outro tempo e lugar. Ela constitui a infância e é meio de superação da mesma.

Dentre as várias contribuições que a brincadeira pode proporcionar, destacase aqui, o que se resulta da mesma em seus momentos de faz-de-conta para a formação da criança, pois o mesmo dá ênfase à imaginação quando vivencia ideias, cria, dramatiza, conta histórias e representa papéis com seus pares. Neste momento, a criança cria numa nova fase de sua capacidade de lidar com a realidade, satisfazendo suas curiosidades e traduzindo o mundo dos adultos para a dimensão de suas necessidades, dentro de suas possibilidades.

Neste contexto, Santos (1999) enfatiza que embora a criança já tenha conhecimento de um objeto ou que tenha vivido alguma situação com ele, a compreensão da experiência fica mais clara quando é representada em seu faz-deconta. Neste momento a criança pode ainda expressar e elaborar de forma simbólica, desejos, conflitos e frustrações. Para a autora, na brincadeira ela consegue vivenciar em seu nível simbólico e ter a compreensão do mundo real, pois essas atividades são importantes para o desenvolvimento do pensamento infantil, uma vez que seu pensamento evolui pela ação representada.

Sobre como acontece esse desenvolvimento, Vygotsky (1989) enfatiza que a brincadeira cria para as crianças uma zona de desenvolvimento proximal, que é a distância entre o nível atual de desenvolvimento, determinada pela capacidade de resolver independentemente um problema e o nível de desenvolvimento potencial, determinado através da resolução de um problema sob a orientação de um adulto ou com a colaboração de um companheiro mais capaz. 
No faz-de-conta a criança desenvolve suas relações interpessoais ao supor o que o outro pensa a tentar coordenar seu pensamento com o seu parceiro, regulando seu comportamento de acordo com as regras sociais e culturais, cria situações imaginárias podendo assumir diferentes papéis. Assim a brincadeira favorece os processos que estão em constituição ou os que ainda serão aperfeiçoados no desenvolvimento infantil (VYGOTSKY, 1984).

A chave para desenvolver a função simbólica da brincadeira entre as crianças é a possibilidade de poderem representar interpretando o mundo e na busca da construção de novos significados para entendê-lo, a criança internaliza o meio e conquista suas respostas ao representar, pois segundo o RCNEI, "brincar de faz-deconta, por sua vez, possibilita que as crianças reflitam sobre o mundo. [...] atribuindo-Ihes novas significações, imprimindo-Ihe suas ideias e os conhecimentos que tem sobre si mesmo, sobre outras pessoas" (BRASIL, 1998, p. 17).

Nesse sentido o RCNEI (BRASIL, 1998) afirma que a representação no fazde-conta, permite às crianças que transformem seus conhecimentos em conceitos gerais. Assumindo um papel na brincadeira ela deve ter conhecimento de suas características, imita algo já conhecido na vivência familiar, na televisão ou nas literaturas. A fonte de seus conhecimentos é múltipla, mas estes encontram-se ainda, fragmentados. É, portanto, no ato de brincar que a criança estabelece os diferentes vínculos entre o papel assumido, suas competências e as relações que possuem com os outros papéis, tomando consciência disso e generalizando para outras situações da vida cotidiana.

É pertinente ainda ressaltar que a brincadeira de faz-de-conta é imprescindível para a formação da criança enquanto ser social, e ainda entender que nesta é percebido elementos internos e externos em sua constituição, pois para Borba:

\footnotetext{
Esse saber, base comum sobre a qual as crianças desenvolvem coletivamente suas brincadeiras é composto de elementos exteriores e interiores às comunidades infantis. Externamente, pode se ter como fontes a cultura televisiva, o mercado de brinquedos, a educação dos adultos e as práticas culturais com outras crianças e adultos. Internamente, compõe-se de atitudes coletivas e elementos culturais particulares (regras, modos de falar e fazer, valores, técnicas, artefatos, etc.) gerados nas práticas e reinterpretações de elementos externos. (BORBA, 2005, p. 39).
}

O desenvolvimento social presente no simbolismo de representar também presente no faz-de-conta é apontado por Vygotsky (1991) como primordial para que funções importantíssimas do ser humano se manifestem no meio. Para o autor, a originalidade do desenvolvimento da criança reside no fato de que as funções naturais, regidas por mecanismos biológicos e as funções culturais, regidas por leis históricas, fundem-se entre si, constituindo um sistema ainda mais complexo.

Diante da importância do todo exposto, é de suma importância, destacar o papel do professor nesse processo, o adulto que intermedia e proporciona os 
momentos de faz-de-conta, pois para Oliveira (2010), a elaboração de novos conceitos sociais dependerá da diversidade, não só quantitativa, mas especialmente, qualitativa das experiências interacionais que a criança viverá nos espaços educacionais.

O professor deve interferir nesses momentos do brincar livre para impedir situações de risco, equilibrar os conflitos, fornecer conhecimentos que ainda precisem atingir e garantir a continuidade da brincadeira. Nesses momentos de intervenção, o professor tem a oportunidade de transmitir valores e a cultura da sociedade, porém, é preciso que seja feito da maneira mais criativa e social possível, independente de seus hábitos, crenças e valores.

\section{Hora do faz-de-conta}

A intervenção realizada foi desenvolvida na E.M.E.I Primeiros Traços, com turmas de pré I e pré II, onde a primeira autora deste texto, Marli Luiz Pereira, leciona no período vespertino como professora de rodízio, ou seja, é professora de cada uma das quatro turmas desse turno, mas somente no parque enquanto a professora regular realiza seu planejamento semanal.

Marli destaca que não foi fácil realizar uma intervenção com turmas de alunos que estão em contato com ela apenas uma vez por semana, pois certamente a convivência diária com a turma facilitaria uma intervenção mais qualitativa.

Objetivando melhorar a qualidade de seu trabalho e ver o significado de estar a cada dia com uma turma diferente no parque, Marli começou a perceber nos estudos teóricos da especialização, mais especificamente na disciplina de Brinquedos e Brincadeiras no Cotidiano da Educação Infantil e também quando foram tratados os conteúdos de Culturas Infantis e Currículo, fundamentos que davam conta da importância desse momento do brincar livre para o desenvolvimento da criança.

Marli ficou fascinada em descobrir que naquele momento as crianças se apropriam da cultura simbólica transformando-a à medida que participam da cultura de pares, quando interagem com esses, representando suas vivências nas brincadeiras, contrapondo a visão predominada de que:

A brincadeira está entre as atividades frequentemente avaliadas por nós como tempo perdido. Como isso ocorre? Ora essa visão é fruto da idéia de a brincadeira é uma atividade oposta ao trabalho, sendo por isso menos importante, uma vez que não se vincula ao mundo produtivo, não gera resultados (BORBA, 2005 p. 35). 
Foram as teorias que orientaram sua intervenção naqueles momentos no parque dando significado tanto para o seu trabalho, quanto para as crianças, entendendo o que faziam ali e o que isso acrescentava para desenvolvimento delas.

Foi realizado uma conversa com as professoras permanentes também neste período vespertino sobre a importância das brincadeiras e o que as crianças estavam construindo na relação com seus pares no brincar livre. Em seguida foram levados por Marli textos relevantes sobre o assunto para que lessem em suas casas e a cada semana que se encontram no parque partilhavam a leitura. Foi muito bom, pois começaram também a ver culturas interessantes serem reveladas e partilhadas nas brincadeiras.

Diante da necessidade de melhoria dos brinquedos a serem utilizados pelas crianças conseguimos algumas doações como brinquedos trazidos de casa, sucatas de vasilhames e garrafas de plástico e realizamos modificações para enriquecer os espaços e todos foram disponibilizados conforme iam sendo adquiridos ou confeccionados, criando, assim, espaços onde se constroem ações conjuntas, onde possam ser feitas amizades, deixando materiais e objetos à disposição das crianças para que pudessem fazer novas descobertas e ressignificações (BORBA, 2005).

Conseguimos melhorar um pouco os espaços. Não conseguimos muita coisa concreta, mas entendemos que a grande importância desse momento no parque está na subjetividade das relações ali partilhadas e construídas e na forma como passamos a observar intervindo nos diálogos e situações de conflitos sabendo da implicância destes para a formação das crianças.

Ao nosso ver, o principal acontece quando nos momentos do faz-de-conta, observamos as falas das crianças com seus pares e o que externalizam do que vivenciam em suas famílias, no contato com a mídia ou com a literatura, revelando as microssociedades internalizadas por essas influências, pois:

Quando brincam, as crianças desenvolvem habilidades cognitivas lingüísticas e sociais. Elas também se apropriam de um domínio mais sólido do conhecimento do mundo adulto. [...] Elas não apenas imitam ou reproduzem aspectos do mundo adulto, mas também confrontam, manipulam e transformam (CORSARO, 2012 p.1).

A intervenção realizada foi muito significativa e a partir de agora vejo elementos de grande importância nesse contexto e procuro sempre valorizar mais as brincadeiras, observando e atentando para a qualidade da intervenção necessária, bem como a melhoria do espaço para que sejam percebidos os resultados do bom faz-de-conta. 


\section{Considerações finais}

Pensar no que a brincadeira representa para a criança é antes de tudo conseguir se esvaziar do conceito neutralizante sobre brincadeira presente nas práticas pedagógicas correntes, repensando ainda a concepção de brincadeira que se tem ao tentar interferir significativamente no faz-de-conta. Conseguir êxito nas brincadeiras requer um novo direcionamento de conscientização, mas antes de tudo, de mobilização na ação prática.

O exposto sobre a importância da brincadeira para a fantasia e sua influência para a formação social da criança, reporta à reflexão de como podem ser proporcionados esses momentos, como enriquecê-los recorrendo também aos que podem promover mudanças de grande porte na estrutura física das dependências das escolas de Educação Infantil, objetivando ambientes ricos em possibilidades.

Perceber que a forma qualitativa ou não que a criança hoje brinca influencia em sua vida adulta aponta para a grande responsabilidade que se tem ao ser educadora, principalmente nos tempos atuais onde a mídia oferece tantos jogos individualizados, diminuindo as possibilidades de interações da criança com seus pares e até mesmo com os adultos.

Deve ser repensada ainda a concepção de brincadeira que se tem para não esvaziá-la de seu sentido criativo, volitivo, prazeroso de possibilitar o faz-de-conta. A brincadeira é uma forma da criança representar e internalizar a realidade e isso precisa ser considerado nas práticas pedagógicas infantis.

\section{Referências}

BOMTEMPO, E. Aprendizagem e brinquedo. In: WITTER, G.P.; LOMÔNACO, J.F.B. (Orgs). Psicologia da aprendizagem. São Paulo: EPU, 1987.

BORBA, A. M. Culturas da Infância nos espaços-tempos do brincar: um estudo com criança de 4-6 anos em instituição pública de educação infantil. Tese de doutorado. Faculdade de Educação da Universidade Federal Fluminense. Rio de Janeiro, Niterói: 2005.

BRASIL. Ministério da Educação e do Desporto. Referencial Curricular para a educação infantil/ Secretaria de Educação Fundamental- Brasília: MEC/SEF, 1998.

CORSARO, W. Faz de conta, aprendizagem e infância viva. Revista Pátio Educação Infantil. Impresso no Brasil, Grupo A Editoras, ano X, n.32.p.12-15. Julholsetembro 2012. 
FORTUNA, T. R.. O lugar do brincar na Educação Infantil. Revista Pátio Educação Infantil. Impresso no Brasil, Grupo A Editoras, ano IX n.27, p. 8-10, abrill junho 2012.

KISHIMOTO, T. O brinquedo na educação: Considerações históricas. In: O Cotidiano na pré-escola, n.7, São Paulo, FDE, 1990.

OLIVEIRA, Z. de M. R. de (Org.). Educação infantil: muitos olhares. 4. ed. São Paulo: Cortez, 2010.

PIAGET, J. A formação do símbolo na criança: imitação, jogo e sonho, imagem e representação. 3. ed. Rio de Janeiro: Zahar Editores, 1978.

SANTOS, S. M. P. dos (Org.). Brinquedoteca: o lúdico em diferentes contextos. 4. ed. Petrópolis: Vozes, 1999.

VYGOTSKY, L. A formação social da mente. São Paulo: Martins Fontes, 1984.

A formação social da mente. São Paulo: Martins Fontes, 1989.

A formação social da mente. S. Paulo: Martins Fontes, 1991.

WAJSKOP, G.. 1995. O brincar na educação infantil. Caderno de Pesquisa, São Paulo, 1995. 


\section{SOBRE AS AUTORAS E AUTORES}

ALINE ZORZI SCHULTHEIS DE FREITAS: Graduada em Pedagogia pela Universidade Federal de Rondônia (2010). Atualmente é pedagoga do Instituto Federal de Educação, Ciência e Tecnologia do Amazonas. Atuando principalmente nos seguintes temas: Educação e Tecnologias da Informação e Comunicação. Email: alineschultheis@hotmail.com

ADRIANA L. DE O. RODRIGUES: Professora da Universidade Federal de Rondônia - UNIR. E-mail: adrianapissinati@yhaoo.com.br.

ADRIANO MORO: Doutorando em Psicologia Educacional pela Faculdade de Educação - UNICAMP, Mestre em Psicologia da Educação pela Pontifícia Universidade Católica de São Paulo - PUC-SP, especialista em Psicopedagogia e possui licenciatura plena em Educação Física pela Faculdade Ítalo Brasileira. É integrante do GEPEM - Grupo de Estudos e Pesquisas em Educação Moral UNICAMP. Atua como Assistente Técnico de Pesquisas e Avaliações Educacionais na Fundação Carlos Chagas - São Paulo - SP. Principais temas de atuação: desenvolvimento moral, educação moral e representações sociais. E-mail: moroadriano@uol.com.br; amoro@fcc.org.br.

CLEOMAR FERREIRA GOMES: professor-pesquisador da faculdade de Educação Física e do programa de mestrado e doutorado em educação da UFMT. Doutorou-se em Antropologia Educacional pela US, com pós-doutorado em Educação pela UFF e recebeu o título de especialista em Ciências do Jogo pela Universidade de Paris XIII. Atualmente se dedica aos aspectos socioantropológicos do corpo em conjunção com fenômenos educativos da ludicidade, do lazer e da alegria nas instituições escolares. E-mail: gomescleo.cg@gmail.com. 
DENISE FRANCO DALLA ROSA: Formada em Pedagogia com Especialização em Orientação Supervisão e Gestão Escolar e em Psicopedagogia Institucional e Clínica. É professora da rede Municipal de Educação de Vilhena atuando em turmas de Educação Infantil e Creche.

DEUSODETE RITA DA SILVA AIMI: Possui graduação em Pedagogia pela Universidade Federal de Rondônia - UNIR (2007), Especialização em Psicopedagogia pela ESAB Escola Superior Aberta do Brasil (2009), Especialização em Educação Especial para o Atendimento Educacional Especializado (AEE) pela Universidade Federal do Ceará e mestrado em Psicologia pela UNIR. Integrante do Grupo de Estudos e Pesquisas em Política e Formação Docente da UFMT. Atualmente é vice-presidente do Conselho Municipal de Direito da Criança e do adolescente de Vilhena. E-mail: deusodetersa@gmail.com.

FABIANO TADEU GRAZIOLI: Possui Mestrado em Letras - Estudos Literários cursado na mesma instituição, Especialização em Metodologia do Ensino de Literatura pela Universidade Regional Integrada do Alto Uruguai e das Missões e Graduação em Letras - Português / Espanhol e respectivas Literaturas pela mesma universidade. É Professor da Universidade Regional Integrada do Alto Uruguai e das Missões e da Faculdade Anglicana de Erechim. Desenvolve projetos sobre os temas Leitura, Literatura e Teatro junto a prefeituras e instituições por intermédio da Dueto Produções Culturais e Artísticas Ltda., produtora cultural da qual é sócio-proprietário. Coordena o segmento de Literatura Infantojuvenil da Habilis Press Editora. E-mail: tadeugraz@yahoo.com.br.

JANÍS HILÁRIO BARROSO: Graduada em Pedagogia pela Universidade Federal de Rondônia. E-mail: janis_bia@hotmail.com.

JOÃO CLEMENTE DE SOUZA NETO: Professor adjunto da Universidade Presbiteriana Mackenzie (UPM). É Mestre e Doutor em Ciências Sociais, Pós-Doutor em Sociologia Clínica, pela Pontifícia Universidade Católica de São Paulo, PUCSP; membro do Socius (da Universidade Técnica de Lisboa), do Núcleo de Pesquisa de Pedagogia Social (FEUSP) e do Instituto Catequético Secular São José (ICA), consultor da Prattein e coordenador da Pastoral do Menor (Ages) da Região Episcopal Lapa, São Paulo. Autor de vários livros e artigos sobre os direitos da infância e da adolescência. E-mail: j.clemente@uol.com.br. 
JOSÉLIA GOMES NEVES: Graduação em Pedagogia. Doutora em Educação Escolar (UNESP - Campus de Araraquara). Professora da Fundação Universidade Federal de Rondônia UNIR - Campus de Ji-Paraná-RO, Departamento de Ciências Humanas e Sociais - DCHS. Pesquisadora e Líder do Grupo de Pesquisa em Educação na Amazônia - GPEA. E-mail: joseliagomesneves@gmail.com

JURACY MACHADO PACÍFICO: Doutora em Educação Escolar pela Universidade Estadual Paulista (UNESP/2010), Mestre em Psicologia Escolar pela Universidade de São Paulo (USP/2000) e graduada em Pedagogia pela Fundação Universidade Federal de Rondônia (UNIR/1996). Atualmente é Professora Adjunta II da Fundação Universidade Federal de Rondônia, atuando no Curso de Licenciatura em Pedagogia, no Programa de Pós-Graduação em Psicologia, Mestrado Acadêmico (MAPSI) e no Programa de Pós-Graduação em Educação Escolar, Mestrado Profissional (MEPE), do qual é também coordenador-adjunta. Coordena o Curso de Pós-Graduação (lato sensu) em Docência na Educação Infantil (UNIR/UNDIME/MEC) e é Coordenadora Geral do Programa de Consolidação das Licenciaturas (Prodocência). E-mail: juracypacifico@unir.br.

KATHIUSA O'HARA FELIPE: Graduada em Pedagogia pela Associação Vilhenense de Educação e Cultura - AVEC (2004); Habilitação para o Exercício do Magistério dos anos Iniciais do Ensino Fundamental pela Fundação Universidade Federal de Rondônia - UNIR (2006). Especialização em Psicopedagoga pela IESA - Instituto de Ensino Superior da Amazônia (2006). Atua como docente na Escola Municipal de Educação Infantil e Ensino Fundamental Professora Dalila Donadon, em Vilhena RO. E-mail: kathiusaohara@gmail.com.

LUCIENE REGINA PAULINO TOGNETTA: Doutora em Psicologia Escolar pelo Instituto de Psicologia da Universidade de São Paulo, tendo realizado parte do doutorado na Universidade de Genebra, na Suíça. Pós-doutorado pela Universidade do Minho, Portugal. Membro e vice-líder do GEPEM - Grupo de Estudos e Pesquisas em Educação Moral da UNESP e UNICAMP. Professora do Departamento de Psicologia da Educação da Faculdade de Ciências e Letras da Unesp, campus Araraquara. E-mail: Irpaulino@uol.com.br.

MARIA SUZANA DE STEFANO MENIN: Possui graduação em Psicologia, mestrado e doutorado em Psicologia Escolar e do Desenvolvimento Humano pela Universidade de São Paulo e dois Pós-Doutorados na École des Hautes Études en Sciences Sociales (1996 e 2004). É Professora Titular da Universidade Estadual 
Paulista Júlio de Mesquita Filho, campus de Presidente Prudente - SP e pesquisadora convidada na Fundação Carlos Chagas. Atua principalmente nos seguintes temas: educação, representações sociais, desenvolvimento moral e educação moral. E-mail: sumenin@gmail.com; menin@fct.unesp.br.

MARIALVA ROSSI TAVARES: Possui graduação em Pedagogia pela PUC/SP, mestrado em Tecnologia da Educação pelo INPE (Instituto Nacional de Pesquisas Espaciais), doutorado em Psicologia da Educação pela PUC/SP. É pesquisadora sênior do Departamento de Pesquisas Educacionais da Fundação Carlos Chagas/SP. E-mail: mtavares@fcc.org.br.

MARLI LUIZ PEREIRA: Especialista em Docência na Educação Infantil. Universidade Federal de Rondônia - UNIR. E-mail: marliluizpereira@hotmail.com.

PATRICIA UNGER RAPHAEL BATAGLIA: Psicóloga (PUC-SP), mestre e doutora em Psicologia Social pela Universidade de São Paulo. Professora da Universidade Estadual Paulista Júlio de Mesquita Filho, campus de Marília - SP. Atua principalmente nos seguintes temas: educação moral, desenvolvimento moral e instrumentos de avaliação do juízo e competência morais. E-mail: patriciaurbataglia@gmail.com.

PETERSON DA PAZ: Licenciado em Pedagogia pela Fundação Universidade Federal de Rondônia - UNIR (2005) e Mestre em Educação pela Universidade Federal de Mato Grosso - UFMT (2013). Atua como docente na rede municipal de Vilhena e na Faculdade de Educação e Cultura de Vilhena - FAEC/UNESC. E-mail: petersondapaz@gmail.com.

RAUL ARAGÃO MARTINS: Possui graduação em Psicologia, mestrado e doutorado em Psicologia do Desenvolvimento pela Fundação Getúlio Vargas - Rio de Janeiro. Pós-Doutorados na "The University of Washington" Seattle, USA (2002-03). É professor Livre Docente da Universidade Estadual Paulista - UNESP, campus São José do Rio Preto - SP. Atua principalmente nos seguintes temas: educação, desenvolvimento moral e educação moral, vulnerabilidades de crianças e adolescentes. E-mail: raul@ibilce.unesp.br. 
RENATA APARECIDA CARBONE MIZUSAKI: Pedagoga e Mestre em Educação pela Universidade Estadual Paulista (UNESP/Campus de Presidente Prudente/SP). Professora da Universidade Federal de Rondônia (UNIR/Campus de Vilhena/RO). Doutoranda em Educação pela Universidade Federal de Mato Grosso (UFMT/Campus de Cuiabá/MT). E-mail: renatamizusaki@hotmail.com.

RODRIGO DA COSTA ARAUJO: Mestre em Ciência da Arte [2008] pela Universidade Federal Fluminense. Professor de Teoria da Literatura, Literatura infantojuvenil e Arte Educação da FAFIMA - Faculdade de Filosofia Ciências e Letras de Macaé. Tem experiência na área de Letras, com ênfase em Literatura Comparada, atuando principalmente nos seguintes temas: Decadentismo, artes, semiótica e literatura, códigos e linguagens, literatura e cinema, literatura infantojuvenil. E-mail: rodricoara@uol.com.br.

ROSEMAR EURICO COENGA: Possui graduação em Letras Habilitação Português Francês pela Universidade Federal de Mato Grosso (1999), Mestrado em Educação pela Universidade Federal de Mato Grosso (2003) e Doutorado em Programa de Pós-Graduação em Literatura pela Universidade de Brasília (2011). Pós-Doutorando pela Universidade de São Paulo. Tem experiência na área de Letras - Língua Portuguesa e Literatura Brasileira. E-mail: rcoenga@gmail.com.

ROZANE ALONSO ALVES: Formada em Pedagogia, Mestre em Educação pela Universidade Federal do Rio Grande do Sul - URFGS. Doutoranda do Programa de Pós-Graduação em Educação da Universidade Católica Dom Bosco - UCDB. Pesquisadora do Grupo de Pesquisa em Educação na Amazônia - GPEA. E-mail: rosane rozanealonso@gmail.com

TELMA P. VINHA: Pedagoga, doutora em educação na área de psicologia, desenvolvimento humano e educação pela Faculdade de Educação da Unicamp e professora do departamento de psicologia educacional desta mesma instituição. Realiza pesquisas na área das relações interpessoais e o desenvolvimento moral, sendo membro do Laboratório de Psicologia Genética da Unicamp e do Grupo de Estudos e Pesquisa em Educação Moral da Unesp. Autora de livros e artigos diversos. E-mail: telmavinha@uol.com.br. 

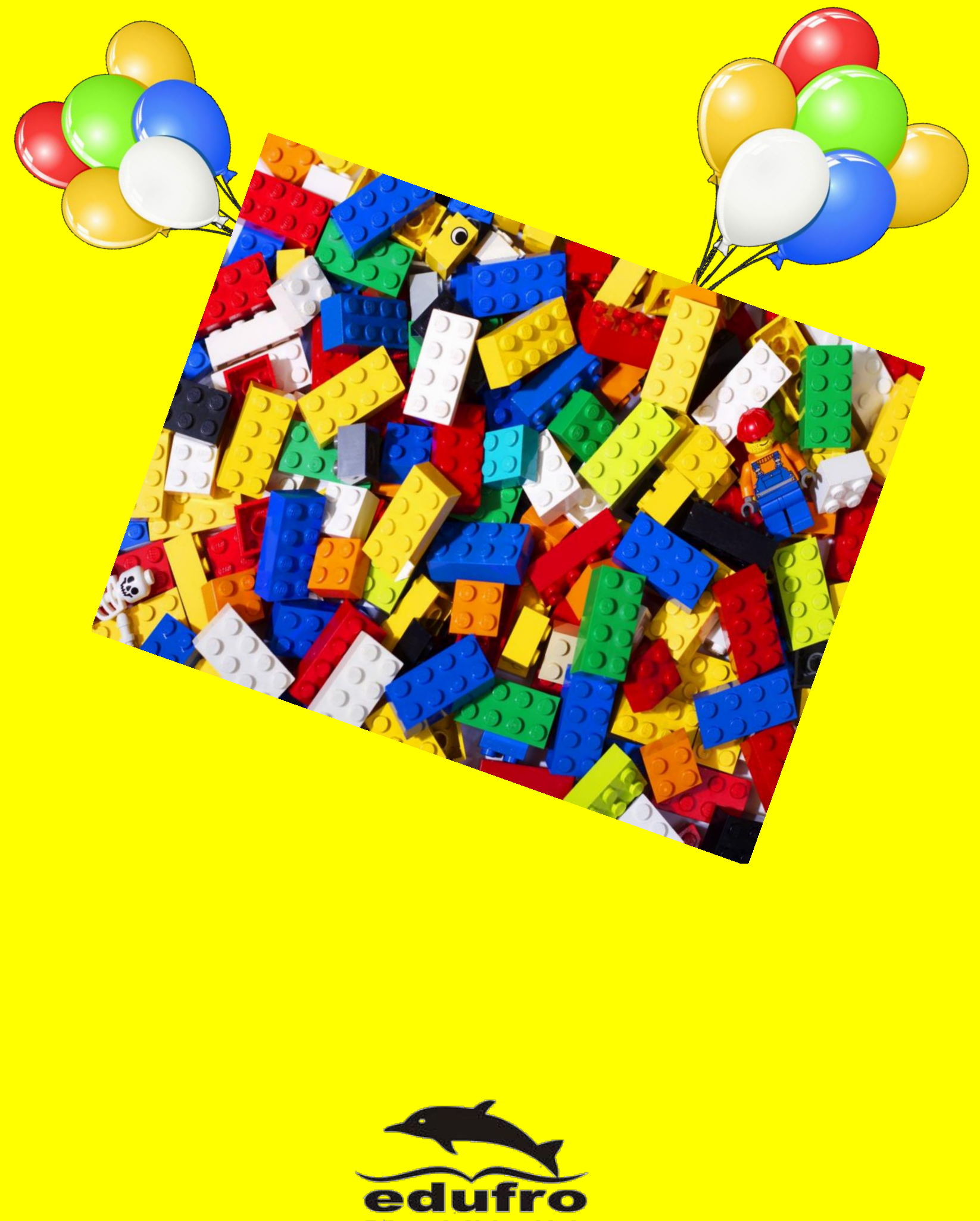

Editora da Universidade Federal de Rondônia 